\title{
MONOGRAPH
}

\section{A key to the bats (Mammalia: Chiroptera) of South Asia}

C. Srinivasulu, Paul A. Racey \& Shahroukh Mistry

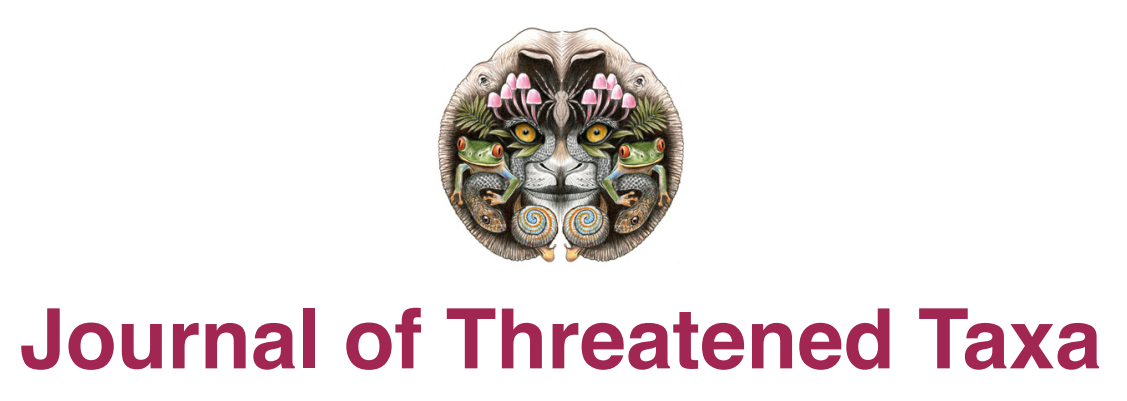


Journal of Threatened Taxa

ISSN 0974-7907 (online) | 0974-7893 (print)

\section{Monograph}

Date of publication (online): 05 July 2010

Date of publication (print): 05 July 2010

ISBN 978-81-902319-0-9 (online) | 978-81-902319-1-3 (print)

Editor: Csorba Gabor

Manuscript details:

Ms \# 02352

Received 28 November 2009

Final revised received 14 April 2010

Finally accepted 19 April 2010

Citation: Srinivasulu, C., P.A. Racey \& S. Mistry (2010). A key to the bats (Mammalia: Chiroptera) of South Asia. Journal of Threatened Taxa 2(7): 1001-1076.

Copyright: (c) C. Srinivasulu, Paul A. Racey \& Shahroukh Mistry 2010. Creative Commons Attribution 3.0 Unported License. JoTT allows unrestricted use of this article in any medium for non-profit purposes, reproduction and distribution by providing adequate credit to the authors and the source of publication.

\section{Author Details}

DR. C. SRINIVAsulu is an Assistant Professor of Zoology at University College of Science, Osmania University, India. He heads the research laboratory at Osmania University that focuses on biodiversity inventorying, conservation, ecology and animal taxonomy (including bats) with special reference to Eastern Ghats and Godavari River basin in Andhra Pradesh.

Professor Paul A. Racey is a Regius Professor of Natural History (Emeritus) at University of Aberdeen, UK and a Visiting Professor at University of Exeter, UK. He is a renowned bat specialist and is CoChair, Bat Specialist Group of IUCN's Species Survival Commission and Vice-Chairman, Fauna and Flora International.

Dr. Shahroukh Mistry is at the Biological Sciences Department, Butte College, California, USA and is a member of Scientific Advisory Board of Bat Conservation International, Austin, Texas, USA and Chair, Board of Directors of North American Society of Bat Researchers.

\section{Author Contributions}

C. Srinivasulu did the ground work to prepare the key. C. Srinivasulu and Paul Racey worked on microchiroptera key, while C. Srinivasulu and Shahroukh Mistry worked on megachiroptera key. All the authors contributed equally in refining and finalizing the key. 


\section{A key to the bats (Mammalia: Chiroptera) of South Asia}

\section{Srinivasulu ${ }^{1}$, Paul A. Racey ${ }^{2} \&$ Shahroukh Mistry ${ }^{3,4}$}

${ }^{1}$ Wildlife Biology Section, Department of Zoology, Osmania University, Hyderabad, Andhra Pradesh 500007, India

${ }^{2}$ Centre for Ecology and Conservation, School of BioSciences, University of Exeter, Tremough Campus, Penryn, TR10 9EZ, United Kingdom

${ }^{3}$ Biology Department, Butte College, 3536 Butte Campus Drive, Oroville, CA 95965, USA

${ }^{4}$ Biological Sciences, California State University, Chico, CA 95929, USA

Email: ${ }^{1}$ csrinivasulu@osmania.ac.in, ${ }^{2}$ p.racey@abdn.ac.uk, ${ }^{3}$ mistrysh@butte.edu

Abstract: A checklist and dichotomous key to 128 species of bats known from South Asia including Afghanistan, India, Pakistan, Nepal, Bhutan, Bangladesh, Sri Lanka and Maldives is provided. Character matrices for families, genera and species are also included. This article also briefly reviews their distribution (both physiographic and country-wise), status and main identification characters.

Keywords: Checklist, Chiroptera, dichotomous key, diversity, Mammalia, South Asia

\section{Table of Contents}

Acknowledgements 1006

Introduction 1007

Scope of this article 1007

Taxonomic composition and endemicity of the bats of South Asia 1007

Characters used for identification of bats 1007

Brief notes on Bats of South Asia 1011

Family Pteropodidae 1011

Brief descriptions of the genera of family Pteropodidae present in South Asia ............................................................... 1011

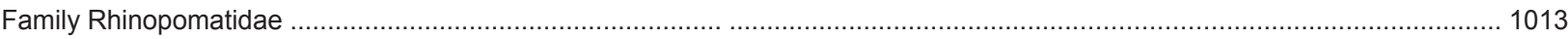

Brief description of the genus of the family Rhinopomatidae present in South Asia ......................................................... 1013

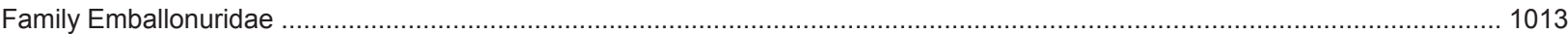

Brief descriptions of the genera of the family Emballonuridae present in South Asia ....................................................... 1013

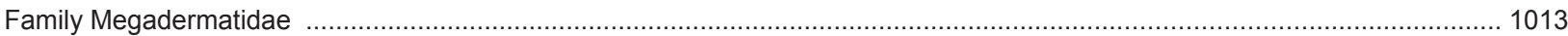

Brief description of the genus of the family Megadermatidae present in South Asia …...................................................... 1013

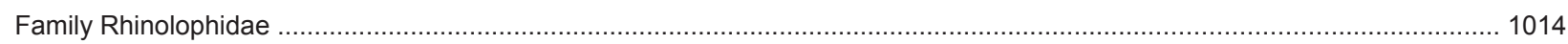

Brief description of the genus of the family Rhinolophidae present in South Asia ............................................................ 1014

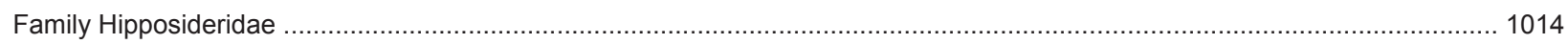

Brief descriptions of the genera of the family Hipposideridae present in South Asia ....................................................... 1014

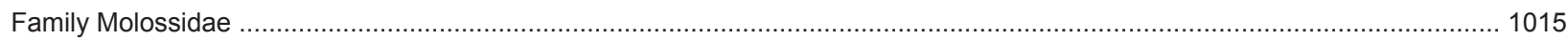

Brief descriptions of the genera of the family Molossidae present in South Asia …....................................................... 1015

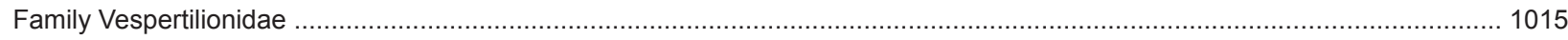

Journal of Threatened Taxa I www.threatenedtaxa.org I July 2010 I 2(7): 1001-1076 1003 
Appendix I. Some important literature consulted to prepare the key

Table 1. Classical and modern classification of bats

Table 2. Checklist of bats of South Asia

Key to the Suborders and the Families

Key 1 , Family Pteropodidae (13 species) 1026

Key 2 Family Megadermatidae (2 species)

Key 3, Family Rhinopomatidae (3 species) 1026

Key 4, Family Rhinolophidae (20 species) 1027

Key 5, Family Hipposideridae (15 species) 1029

Key 6, For subfamilies of the family Vespertilionidae (63 species) 1031

Key 6A, Subfamily Murininae (8 species) 1032

Key 6B, Subfamily Kerivoulinae (3 species) 1033

Key 6C, Subfamily Myotinae (14 species)

Key $6 \mathrm{D}$, For tribes of the subfamily Vespertilioninae (38 species)

Key 6D i, Tribe Plecotini (5 species)

Key 6D ii, Tribe Nycticeiini (4 species) 1037

Key 6D iii, Tribe Eptesicini (9 species) 1038

Key 6D iv, Tribe Pipistrellini (12 species) 1039

Key 6D v, Tribe Vespertilionini (8 species) 1041

Key 7, Family Miniopteridae (3 species) 1042

Key 8, Family Emballonuridae (6 species) 1043

Key 9, Family Molossidae (4 species) 1043

Table 3. Diagnostic morphological characters of eight genera of the family Pteropodidae present in South Asia 1044

Table 3.1. Diagnostic morphological characters of the two species of the genus Rousettus Gray, 1821 present in South Asia .... 1045

Table 3.2. Diagnostic morphological characters of four species of the genus Pteropus Brisson, 1762 present in South Asia ....... 1045

Table 3.3. Diagnostic morphological characters of the two species of the genus Cynopterus Cuvier, F., 1824 present in South Asia ...

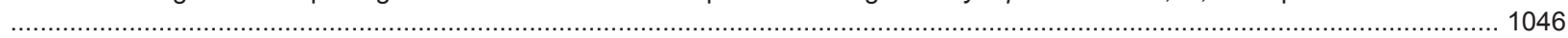

Table 3.4. Diagnostic morphological characters of the species of the genera Megaerops Peters, 1865; Latidens Thonlongya, 1972; Sphaerias Miller, 1906; Eonycteris Dobson, 1873; and Macroglossus Cuvier, F., 1824 present in South Asia

Table 4. Diagnostic morphological characters of the genera of the families Rhinopomatidae, Emballonuridae, Megadermatidae and Rhinolophidae present in South Asia

Table 4.1. Diagnostic morphological characters of the three species of the genus Rhinopoma E. Geoffroy, 1818 present in South Asia 
Table 4.2. Diagnostic morphological characters of five species of the genera Taphozous E. Geoffroy, 1818 and Saccolaimus Lesson, 1842 present in South Asia

Table 4.3. Diagnostic morphological characters of the two species of the genus Megaderma E. Geoffroy, 1810 present in South Asia 1048

Table 4.4. Diagnostic morphological characters of twenty species of the genus Rhinolophus Lacépède, 1799 present in South Asia ..

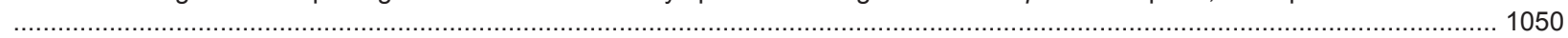

Table 5. Diagnostic morphological characters of the genera of the family Hipposideridae present in South Asia 1054

Table 5.1. Diagnostic morphological characters of twelve species of the genus Hipposideros Gray, 1831 present in South Asia...1055

Table 5.2. Diagnostic morphological characters of one species each of the genera Triaenops Dobson, 1871; Asellia Gray, 1838; and Coelops Blyth, 1848 present in South Asia

Table 6. Diagnostic morphological characters of the genera of the family Molossidae present in South Asia

Table 6.1. Diagnostic morphological characters of the species of the genera Tadarida Rafinesque, 1814, Chaerephon Dobson, 1874

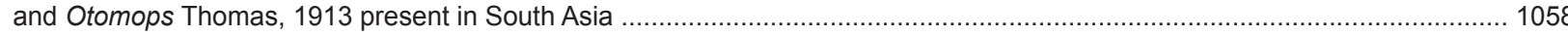

Table 7. Diagnostic morphological characters of the genera of the family Vespertilionidae present in South Asia ..................... 1059

Table 7.1. Diagnostic morphological characters of the species belonging to the genera Harpiocephalus, Harpiola and Murina present

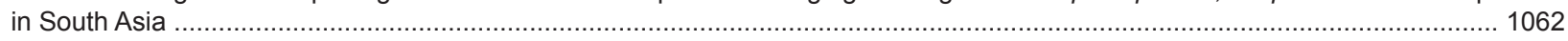

Table 7.2. Diagnostic morphological characters of the species of the genus Kerivoula present in South Asia 1063

Table 7.3. Diagnostic morphological characters of the species belonging to the genus Myotis Kaup, 1829 present in South Asia

Table 7.4. Diagnostic morphological characters of the species belonging to the genera Plecotus, Barbastella and Otonycteris present in South Asia

Table 7.5. Diagnostic morphological characters of the species belonging to the genera Scotoecus, Scotomanes and Scotophilus present in South Asia .

Table 7.6. Diagnostic morphological characters of the species belonging to the genus Arielulus, Hesperoptenus and Eptesicus present in South Asia

Table 7.7. Diagnostic morphological characters of the species belonging to the genera Nyctalus, Scotozous and Pipistrellus present in South Asia

Table 7.8. Diagnostic morphological characters of species of the genera Tylonycteris, la, Falsistrellus, Vespertilio, Philetor and Hypsugo present in South Asia

Table 8. Diagnostic morphological characters of one genus of the family Miniopteridae present in South Asia 1070

Table 8.1. Diagnostic morphological characters of species of the genera Miniopterus Bonaparte, 1837 present in South Asia .... 1071 


\section{ACKNOWLEDGEMENTS}

We heartily acknowledge all the bat field researchers and taxonomists from the region and elsewhere whose published materials we relied upon to prepare this key. Many thanks are due to Dr. Paul J.J. Bates and Malcolm Pearch, Harrison Zoological Institute, Sevenoaks, UK; Dr. Y.P. Sinha, Retired Scientist, Gangetic Plains Research Station, Zoological Survey of India, Patna; Dr. A.M. Hutson, IUCN/SSC/Chiroptera Specialist Group, East Sussex, UK; and Dr. M.S. Pradhan, Retired Scientist, Western Ghats Regional Station, Zoological Survey of India, Pune for their encouragement, advice, support, comments and supply of important publications. We thank Dr. Ramakrishna, Director, Zoological Survey of India, Kolkata for permission to study the chiropteran collection and Dr. S.S. Saha, Dr. T.P. Bhattacharyya and Mr. M.K. Ghosh for helping during the specimen studies. Dr. G. Marimuthu and Dr. K. Sripathi of Madurai Kamaraj University, their other colleagues and students deserve special thanks for their support during our visits to Madurai, especially during the South Asian Chiroptera CAMP Workshop. We also thank Dr. A. Madhavan, India; Dr. J.C. Daniel, Bombay Natural History Society, India; Dr. Manoj Muni, India; Dr. Wipula Yapa, University of Colombo, Sri Lanka; Mr. K.M. Swe, University of Yangon, Myanmar; Dr. T.K. Shrestha, Tribhuvan University, Nepal, and all other bat researchers, especially the CCINSA members, for sharing their knowledge. We thank Dr. Wilma Jogunuri and Dr. Priya Raman, University of Arizona, USA for helping with references; Ms. Sally Walker and Mr. Sanjay Molur, Zoo Outreach Organization, Coimbatore for encouragement; Ms. Binu Priya, Ms. Padma Priya, and Ms. J. Sheela of Zoo Outreach Organization who never once minded scores of untimely and numerous requests for references and other information. We thank Dr. Bhargavi Srinivasulu and Aditya Srinivasulu for help in the preparation of the manuscript and initial checks and Dr. Neil Furey, FFI Cambodia for last minute tweaking. We thank Dr. G. Csorba, Head, Mammal Collection, Department of Zoology, Hungarian Natural History Museum, Budapest for his very valuable suggestions and inputs. We are also grateful to field researchers in South Asia who tested the key from 2002 to 2009 and responded with positive comments to incorporate amendments. The first author acknowledges the post doctoral research grant by Council for Scientific and Industrial Research, New Delhi to work on fruit bat taxonomy in India.
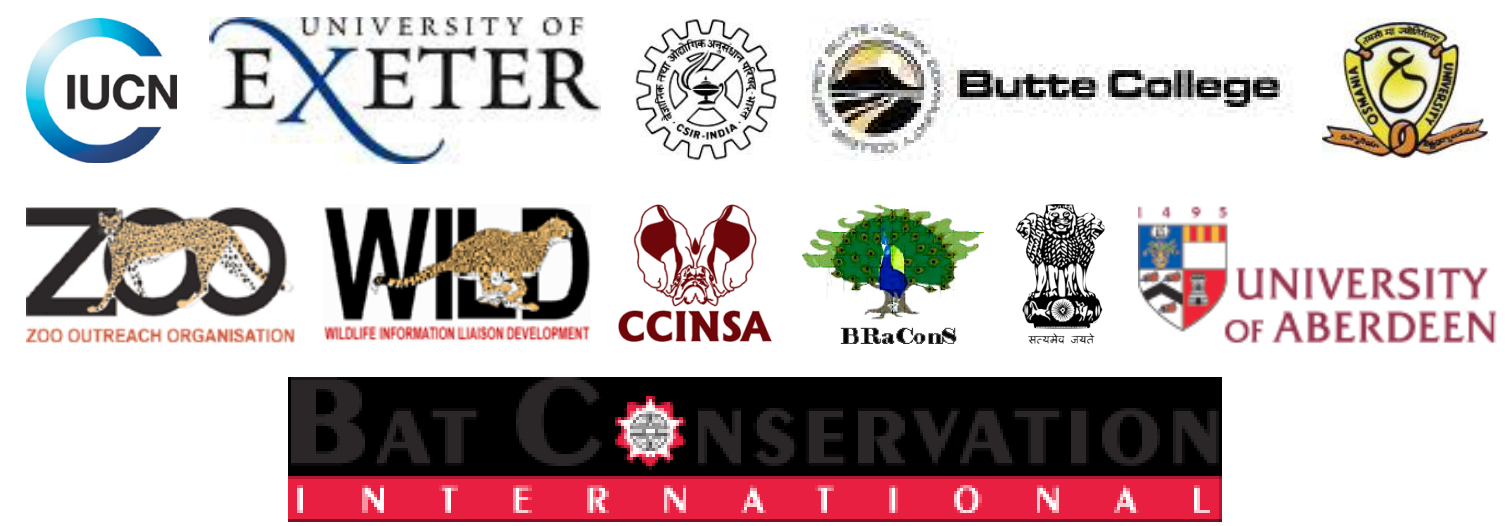


\section{INTRODUCTION}

Of the rich diversity of vertebrate fauna, bats are unique in being the only group of mammals that, like birds, have sustained flight. One of the 26 mammalian orders, the Chiroptera includes 1117 species of bats world over in rather two unequal suborders the Megachiroptera (consisting 186 species of Old World fruit bats in one family) and the Microchiroptera (consisting 931 species in 17 families) (Mickleburgh et al. 1992; Koopman 1993; Srinivasulu \& Srinivasulu 2001; Hutson et al. 2001; Mickleburgh et al. 2002; Simmons 2005). Recent molecular phylogenetic studies challenged this traditional subdivision and proposed that the bats be subdivided into two new suborders (Table 1), Yinpterochiroptera (includes the families Pteropodidae, Rhinolophidae, Megadermatidae and Rhinopomatidae) and Yangochiroptera (includes all the remaining families) (Teeling et al. 2005). However, until the new suborders are widely accepted, we prefer to retain the traditional subdivision.

Bats are widely distributed and have been recorded throughout the world excepting the Antarctic and a few Oceanic Islands (Mickleburgh et al. 2002). Some of the bat families are widespread and are recorded from both the Old World and the New World. Others are restricted in their range and are recorded either only from the Old World or the New World. Of the 18 families of bats, eight families (Pteropodidae, Rhinopomatidae, Nycteridae, Megadermatidae, Rhinolophidae, Hipposideridae, Myzopodidae and Mystacinidae) are restricted to the Old World; six families (Noctilionidae, Phyllostomidae, Desmodontidae, Natalidae, Furipteridae and Thyropteridae) are restricted to the New World; and three families (Emballonuridae, Molossidae and Vespertilionidae) are found both in the Old and New Worlds (Mickleburgh et al. 2002; Simmons 2005).

\section{Scope of this article}

Although work on taxonomy and systematics of the region's bat diversity has been considerable (recently reviewed by Bates \& Harrison (1997)), there exists no published material that could help bat researchers in easy identification of bats both in the field and in the laboratory or museum. The necessity of identifying living bats in the field and preserved specimens prompted the preparation of this key. During the Conservation Assessment and Management Plan (CAMP) Workshop on South Asian Bats, held at Madurai in southern India in January 2002, the need for such a key for the South Asian region was felt to be indispensable. Hence, after deliberation and seeking the opinions from fellow bat researchers, the work on the preparation of the key for field identification of all the known species from Afghanistan, India, Pakistan, Nepal, Bhutan, Bangladesh, Sri Lanka and Maldives was undertaken by the first author. We consulted published literature in the process of preparation of this work (Appendix I).

The key, designed for use with a vernier caliper or a millimeter scale and a hand lens, is modified from Blanford (1888-1891), Corbet \& Hill (1992), and Bates \& Harrison (1997). Numerous other publications, listed in the Reference section, were also consulted. As some authorities suggest that keys may lead to some confusion, the present work also incorporates identification character matrices in tabular form for the ease of the user. In the character matrices the dental formula for each genus dealt with in this key is provided. The dental formula includes details of incisors, canines, premolars, molars of one side for both upper and lower jaw followed by total number of teeth present. Variations within genus are denoted by the numerical in parenthesis.

We encourage readers to contact the lead author with suggestions and recommendations so that the key may be kept current.

\section{Taxonomic composition and endemicity of the bats of South Asia:}

A total of 128 species of bats are reported from South Asia (Table 2), with the microchiropterans being better represented than the megachiropterans (115 vs. 13 species). Among the Microchiroptera large number of species are from the family Vespertilionidae, followed by the families Rhinolophidae, Hipposideridae, Emballonuridae, Molossidae, Rhinopomatidae and Megadermatidae (Fig. 1). Of this diversity, 10 species, namely, Pteropus faunulus (Pteropodidae), Pteropus melanotus (Pteropodidae), Latidens salimalii (Pteropodidae), Rhinolophus cognatus (Rhinolophidae), Rhinolophus mitratus (Rhinolophidae), Hipposideros durgadasi (Hipposideridae), Hipposideros hypophyllus (Hipposideridae), Myotis csorbai (Vespertilionidae), Eptesicus tatei (Vespertilionidae) and Harpiola grisea (Vespertilionidae) are endemic to the region. Familywise percent endemicity is greatest in Pteropodidae (21.4) followed by Hipposideridae (13.3), Rhinolophidae (11.7 species) and Vespertilionidae (4.8).

Among the countries representing South Asia, India has more than $90 \%$ of the total bat diversity of this region, while others have less than $50 \%$ diversity (Fig. 2). Bhutan has $51 \%$, Nepal has $40 \%$, Pakistan has $33 \%$, Bangladesh has 29\%, Afghanistan has $28 \%$, Sri Lanka has $23 \%$ and Maldives has $2 \%$ of the total bat diversity of South Asia.

\section{Characters used for identification of bats}

Identification of bats depends upon a series of external, cranial and dental measurements. Besides mensural characters many qualitative characters also help in easy identification, and wherever applicable we 


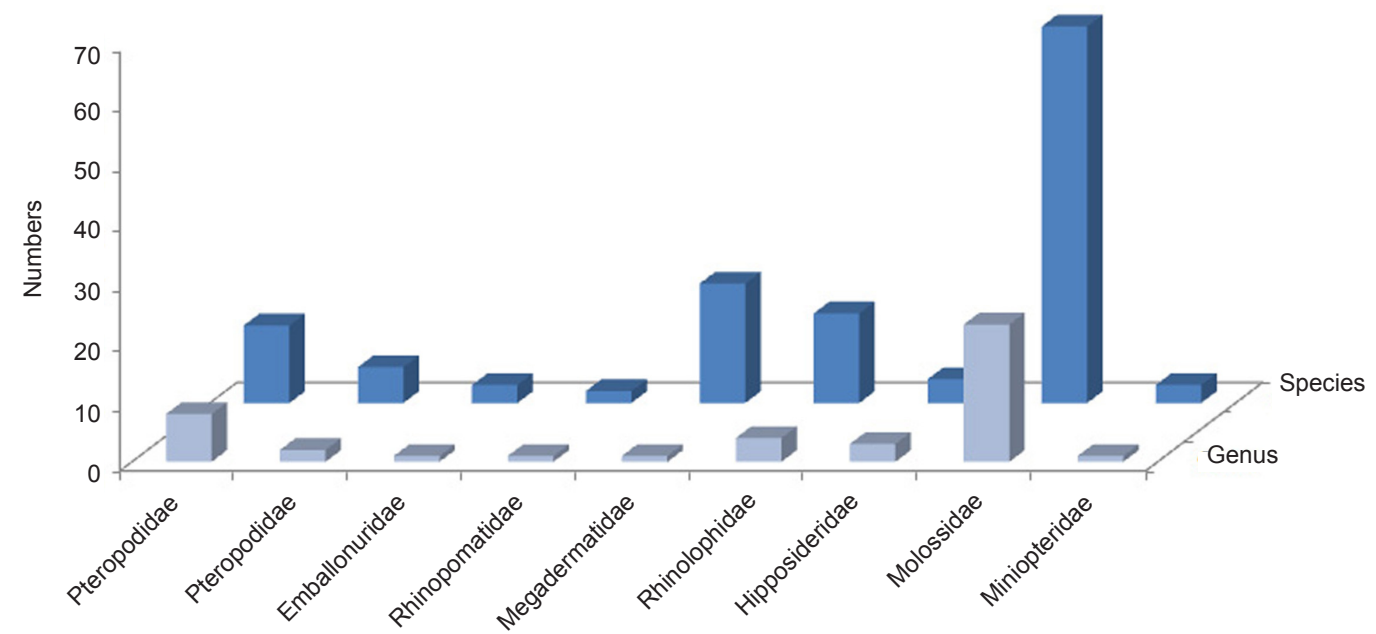

Figure 1. Chiropteran diversity in South Asia

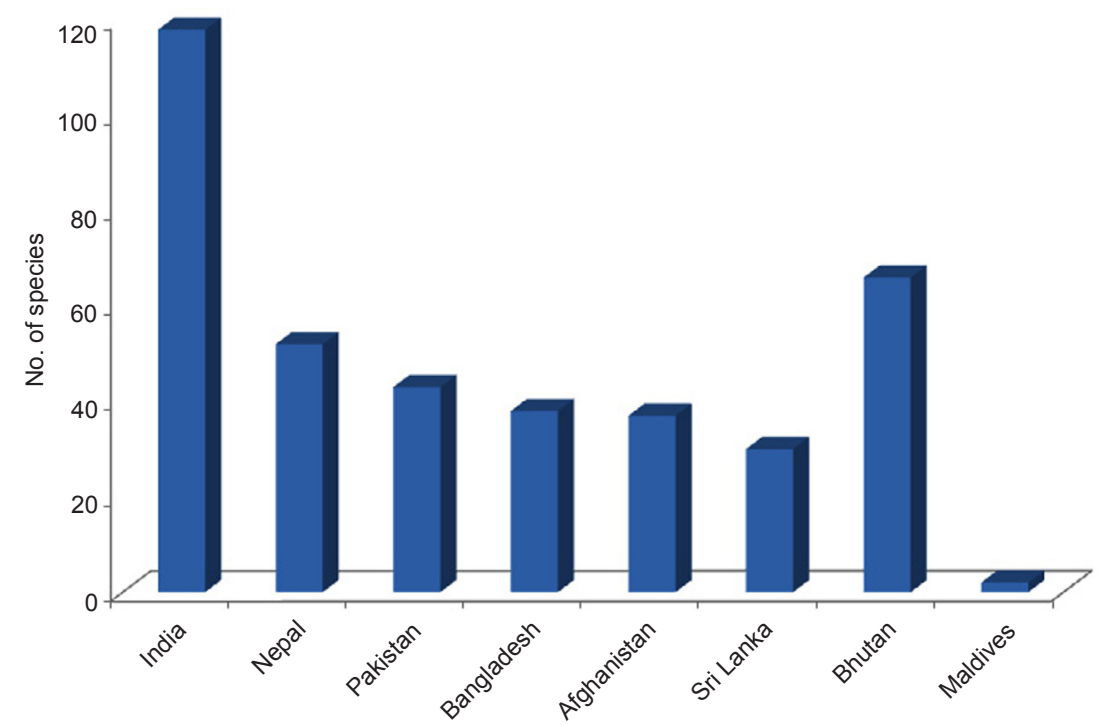

Figure 2. Number of bat species occurring in each country of South Asia

have included these. In this section, various external and cranial (including dental) measurements dealt in the present article as well as those useful in taxonomic studies have been detailed.

\section{External (see Figs. 3a and 3b for details)}

E (Ear length): from the lower border of the external auditory canal to the tip of the pinna, excluding hairs.

FA (Forearm length): taken with the wings folded, from the outer end of the elbow to the outer end of the wrist joint (or carpus).

HB (Head Body length): taken dorsally, from the tip of the snout to the base of the tail.
HF (Hindfoot length): from the outer end of the heel at the base of the calcar to the outer end of the longest digit, excluding hairs or claws.

TL (Tail length): from the base of the tail near the anal opening to tip of the tail.

Some other external measurements that are considered for taxonomic studies include:

3mt (Third metacarpal length): from the outer end of wrist joint (or carpus) to the distal outer end of the metacarpal.

1 ph $3 \mathrm{mt}$ (Length of the first phalanx of the third metacarpal): from the proximal to the distal end of the first phalanx. 
2ph 3mt (Length of the second phalanx of the third metacarpal): from the proximal to the distal end of the second phalanx.

(Note: Similarly, 4mt (length of the fourth metacarpal), $5 \mathrm{mt}$ (length of the fifth metacarpal), $1 \mathrm{ph} 4 \mathrm{mt}$ (Length of the first phalanx of the fourth metacarpal), and $2 \mathrm{ph} 4 \mathrm{mt}$ (Length of the second phalanx of the fourth metacarpal) is also taken in to consideration.)

TIB (Tibia length): taken from the knee joint to the ankle.

Thumb (Thumb length): length of the first digit including metacarpal and phalanx excluding claw.

WSP (Wingspan): maximum spread of the wing from tip to tip taken with wings fully stretched.

Cranial (see Figs. 4 and 5 for details)

CBL (Condylobasal length): from occipito-condyle to the anterior edge of alveolus of the anterior incisor.

CCL (Condylocanine length): from occipito-condyle to the anterior edge of alveolus of the canine.

$\underline{\mathrm{CM}}^{\mathrm{n}}$ (Maxillary toothrow): from the front of the upper canine to the back of the crown of the last upper molar.

$\mathrm{CM}_{n}$ (Mandibular toothrow): from the front of the lower canine to the back of the crown of the last lower molar.

GTL (Greatest length of the skull): from the extreme end of the anterior to the extreme end of the posterior parts of the skull.

M (Mandible length): from the extreme end of the condyle to the extreme end of the anterior of the mandible including the incisors.

$\mathrm{M}^{\mathrm{n}}-\mathrm{M}^{\mathrm{n}}$ (Width across the last molars): taken from the outer borders of the crown of the last upper molars.

ZB (Zygomatic breadth): Greatest width of the skull across the zygomatic arches.

Some other dental and cranial measurements that are considered for taxonomic studies include:

BB (Breadth of the braincase): Greatest width of the brain case.

IC (Interorbital constriction): the narrowest width across the interorbital region.

RW (Rostral width): taken across the front of the orbits at their most anterior point.

\section{Some important terms defined}

Antebrachial membrane: membrane in front of the arm extending between shoulder to forearm, wrist or thumb.

Antitragus: a lobe developed from the basal part of the outer margin of the ear.

Bicuspidate: a tooth possessing two cusps.

Bifid: a structure having two distal processes.

Calcar: a cartilaginous or bony spur like projection arising from the ankle that supports the interfemoral membrane.

Canine: a single tall and pointed tooth situated behind the incisors in each toothrow.

Cusp: a prominence or point on tooth.

Echolocation: navigation in flight by means of the echo of sound pulses.

Gular sac: a glandular pouch like structure in the skin of the throat.

Incisor: a front tooth situated in front of the canine tooth in each toothrow.

Interfemoral membrane: also uropatagium, a membrane extending between inner margins of the legs and the distal end of the body enclosing all or a part of the tail.

Jugal: also malar or the cheekbone, present in the middle of the zygomatic arch.

Lancet: present in the forms belonging to the genus Rhinolophus, it is the erect, subtriangular, posterior part of the nose leaf.

Mandible: the lower jaw composed of two bones, fused to different degrees.

Metacarpal: one of the long bones of the hand of the bat extending from the carpal bones to the proximal phalanx of the finger.

Molar: a posterior cheektooth.

Narial: pertaining to nasal region. 


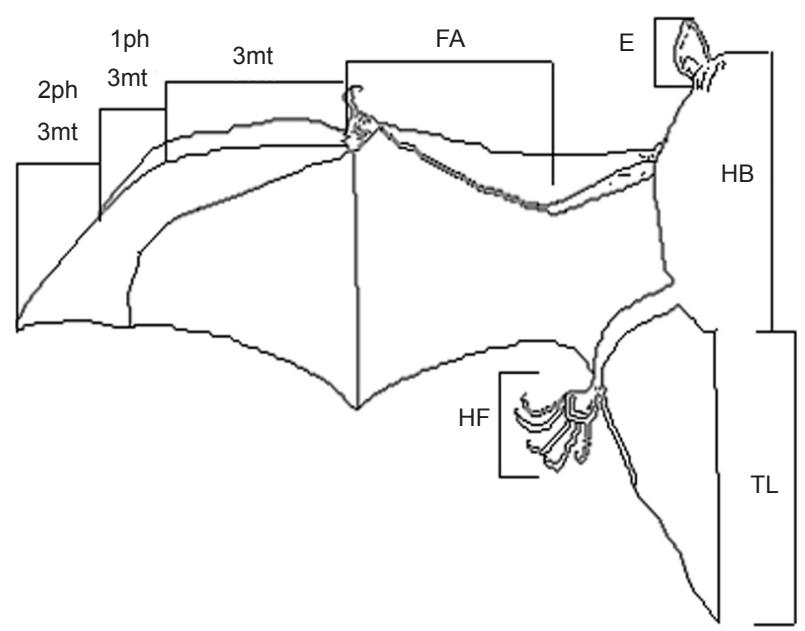

Figure 3a. Schematic diagram of a bat showing important external measurements

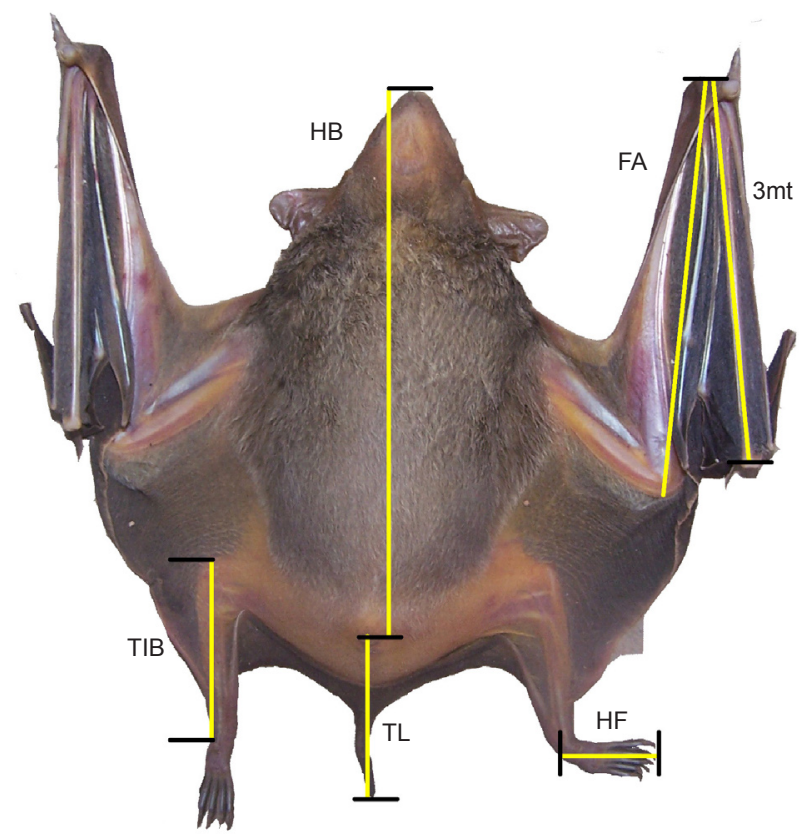

Figure 3b. Important external measurements of Taphozous longimanus

Noseleaf: a simple to complex structure derived from the skin around the nose in some bats.

Pararhinal glands: specialized sebaceous glands on the side of the muzzle.

Phalanx: (plural Phalanges) Digital bone of a finger or toe.

Premolar: a cheektooth in front of the first molar.

Radio-metacarpal pouch: a pocket on the ventral side

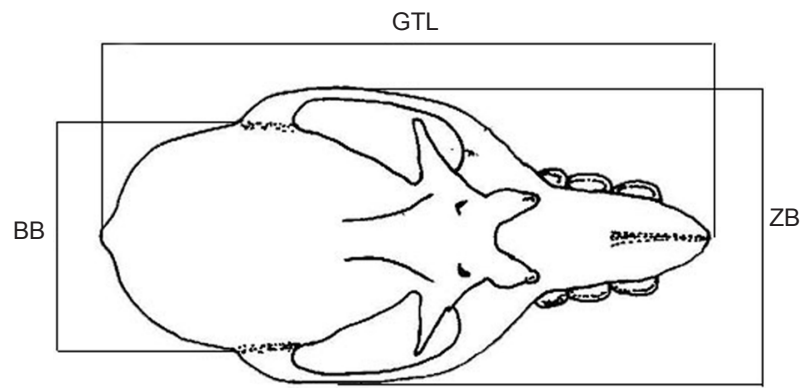

Figure 4. Dorsal view of the skull of Pteropus giganteus

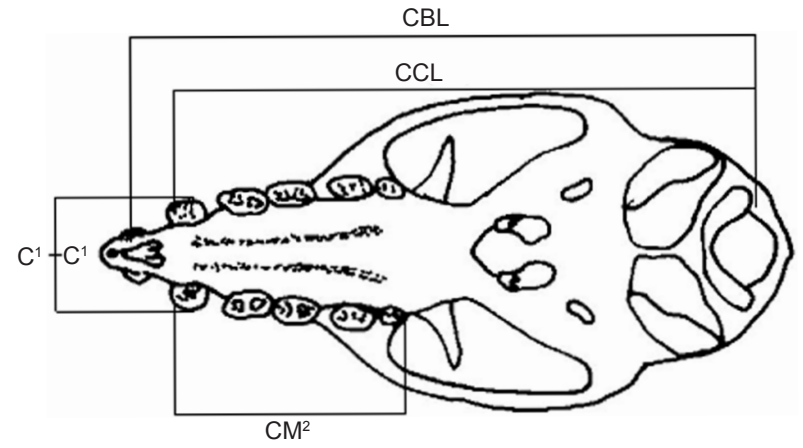

Figure 5. Ventral view of the skull of Pteropus giganteus

of the wing extending between the radius and the fifth metacarpal in some bats.

Rostrum: the facial part of the skull in front of the orbits.

Sella: a median anterior projection of the noseleaf of the genus Rhinolophus (Fig. 6).

Tibia: the bone extending between the knee and the ankle.

Tragus: a cutaneous projection at the opening of the external ear.

Unicuspid: a tooth with single cusp.

Zygoma: (plural Zygomata) The arch of the cheek bone comprising part of squamosal at the base, jugal in centre and part of maxilla in front. 


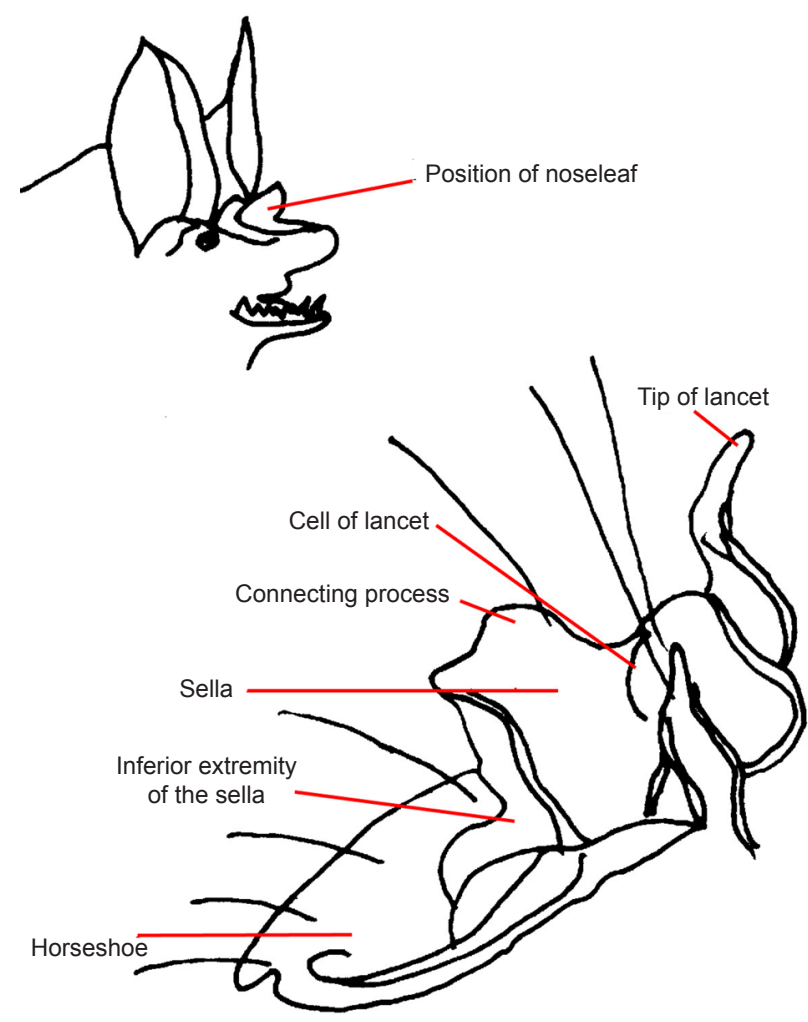

Figure 6. Lateral view of noseleaf of Rhinolophus sinicus

\section{BRIEF NOTES ON BATS OF SOUTH ASIA}

\section{Order Chiroptera \\ Suborder Megachiroptera \\ Family Pteropodidae}

Includes about 186 species of bats that feed chiefly on fruits, leaves, flowers and flower products. Distributed in Europe, Africa, Asia, Australia and Oceania (Mickleburgh et al. 2002; Simmons 2005). They have strong muzzle and jaws. Do not possess noseleaf or tragus. Eyes are large. They possess keen sense of smell. Ears simple (Fig. 7A). Tail small or absent, and proximal part of the caudal vertebrae included, the distal ones are free (Fig. $8 \mathrm{~A})$. Fourteen species belonging to eight genera have been reported from South Asia.

Brief descriptions of the genera of the family Pteropodidae present in South Asia:

Rousettus Gray, 1821 - Medium-sized fruit bats (FA - 75.0-90.0 mm) of rather heavier built and short tail (8.0$21.0 \mathrm{~mm}$ ). Muzzle heavy and has deep emargination between the projecting nostrils. First digit has large claws while the second has smaller ones. Males have welldeveloped glandular hairs on the throat than the females. Echolocate for orientation within roost by clicking tongue against the roof of mouth. Rostrum moderately elongated. Two pairs of lower and upper incisors present. Two species - R. aegyptiacus (E. Geoffroy, 1810) and $R$. leschenaultii (Desmarest, 1820) - occur in South Asia. Diagnostic morphological characters of the genus are provided in Table 3 and those of the species belonging to it in Table 3.1.

Pteropus Brisson, 1762 - Medium to large-sized fruit bats (FA - 110.0-209.0 mm) without tail. Patagium arises from sides of dorsum and the back of the second toe. Uropatagium less developed. Second digit has a small claw. Rostrum moderate. Two pairs of lower and upper incisors present. Four species - $P$. giganteus Brünnich, 1782, P. hypomelanus Temminck, 1853, P. melanotus Blyth, 1863 and $P$. faunulus Miller, 1902 - occur in South Asia. Diagnostic morphological characters of the genus are provided in Table 3 and those of the species belonging to it in Table 3.2.

Cynopterus Cuvier, F., 1824 - Medium-sized fruit bats (FA - 57.0-79.0 mm) with short tail (2.0-19.0 mm) that is half enclosed within the interfemoral membrane. Muzzle short, and has deep emargination between the projecting nostrils. Both the first and second fingers have distinct claws. Rostrum short. Two pairs of lower and upper incisors present. Two species $-C$. sphinx (Vahl, 1797) and C. brachyotis (Müller, 1838) - occur in South Asia. Diagnostic morphological characters of the genus are provided in Table 3 and those of the species belonging to it in Table 3.3.

Megaerops Peters, 1865 - Medium-sized fruit bats (FA - 52.0-63.0 mm) without any external tail. Muzzle short, and has deep emargination between the projecting nostrils. Ears simple with broadly rounded tips. Interfemoral membrane narrow with dorsal medial parts hairy. Rostrum short. Two pairs of upper and one pair of lower incisors present. One species $-M$. niphanae Yenbutra \& Felten, 1983 - occurs in South Asia. Diagnostic morphological characters of the genus are provided in Table 3 and those of the species belonging to it in Table 3.4 .

Latidens Thonglongya, 1972 - Medium-sized fruit bats (FA - 66.0-69.0 mm) without tail. Muzzle long, and has deep emargination between the projecting nostrils. Ears simple and oval, with narrowly rounded tips. Interfemoral membrane with some hairs on upper and lower sides. Rostrum elongated and narrow. Only one pair of lower and upper incisors present. One species L. salimalii Thonglongya, 1972 - occurs in South Asia. Diagnostic morphological characters of the genus are provided in Table 3 and those of the species belonging to it in Table 3.4 .

Sphaerias Miller, 1906 - Medium-sized fruit bats (FA - 52.0-61.0 mm) without tail. Muzzle long, and has deep emargination between the projecting nostrils. Ears with well defined pale anterior margin, and with small triangular antitragal lobe. Interfemoral membrane very narrow and calcar absent. Rostrum long and narrow. Two pairs of lower and upper incisors present. One species 


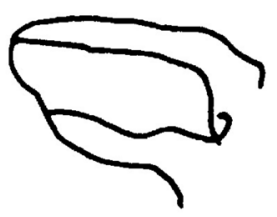

A - Tragus absent

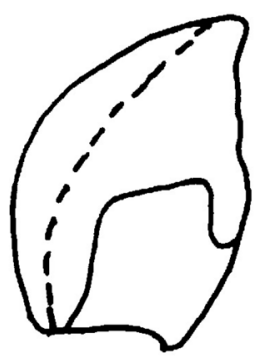

D - Tragus absent Anti-tragus well developed

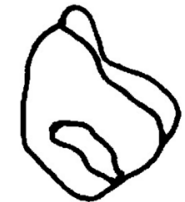

G - Tragus well-developed

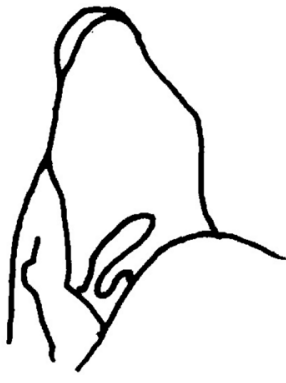

B - Tragus simple
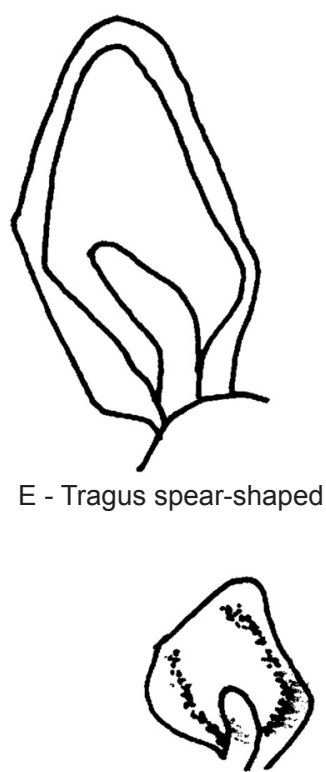
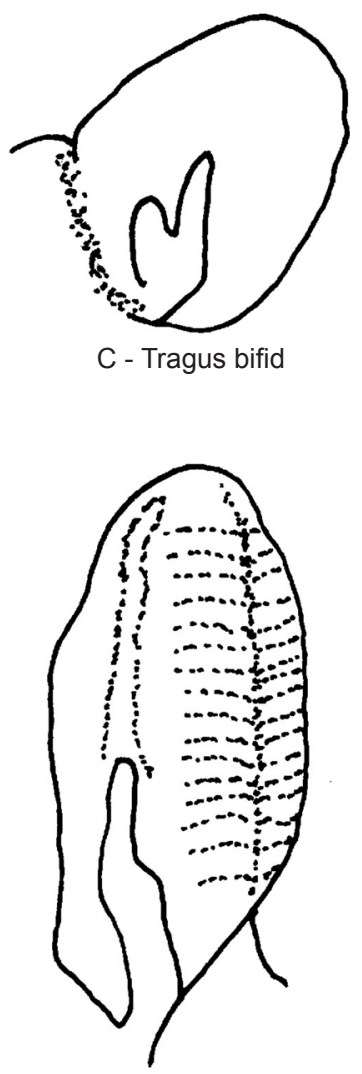

F - Tragus well-developed

Figure 7. Outline of ear and shape of tragus in select species of bats [A - Pteropus giganteus; B - Rhinopoma microphyllum; C - Megaderma lyra; D - Rhinolophus luctus; E - Myotis sp.; F - Plecotus wardi; G - Pipistrellus pipistrellus; H - Miniopterus schreibersi]

- S. blanfordi (Thomas, 1891) - occurs in South Asia. Diagnostic morphological characters of the genus are provided in Table 3 and those of the species belonging to it in Table 3.4.

Eonycteris Dobson, 1873 - Medium-sized fruit bats (FA - 66.0-78.0 mm) with well-developed tail (11.5-23.0 $\mathrm{mm})$. Muzzle long and thin, and has deep emargination between the projecting nostrils. Only the thumb is clawed, second digit lacks claw. Ears are narrowly rounded. Interfemoral membrane very moderately broad, tail and calcar well-developed. A pair of large anal glands present. Tongue is sharply pointed and highly protrusible with well-developed unfringed filiform papillae at the tip. Rostrum long and narrow. Two pairs of lower and upper incisors present. There are usually eight palatal ridges. One species - E. spelaea (Dobson, 1871) - occurs in South Asia. Diagnostic morphological characters of the genus are provided in Table 3 and those of the species belonging to it in Table 3.4.

Macroglossus Cuvier, F., 1824 - Small to medium- sized fruit bats (FA - 44.0-52.0 mm) without or with rudimentary tail (3.5-5.5 $\mathrm{mm})$. Specialized for nectar feeding, muzzle long and narrow. The thumb and the second digit are clawed. Ears medium with narrowly rounded tips, and small antitragal lobes. Interfemoral membrane very narrow and is thickly haired. Tongue is sharply pointed and highly protrusible. Rostrum relatively long and narrow, braincase strongly deflected downwards. Two pairs of lower and upper incisors present. One species - M. sobrinus (K. Andersen, 1911) - occurs in South Asia. Diagnostic morphological characters of the genus are provided in Table 3 and those of the species belonging to it in Table 3.4.

\section{Suborder Microchiroptera Family Rhinopomatidae}

Includes five species of insectivorous bats. Distributed in dry regions of Africa and Asia (Mickleburgh et al. 2002; Simmons 2005). They have strong muzzle with thickened narial pads. Possess rudimentary noseleaf (a distinct 

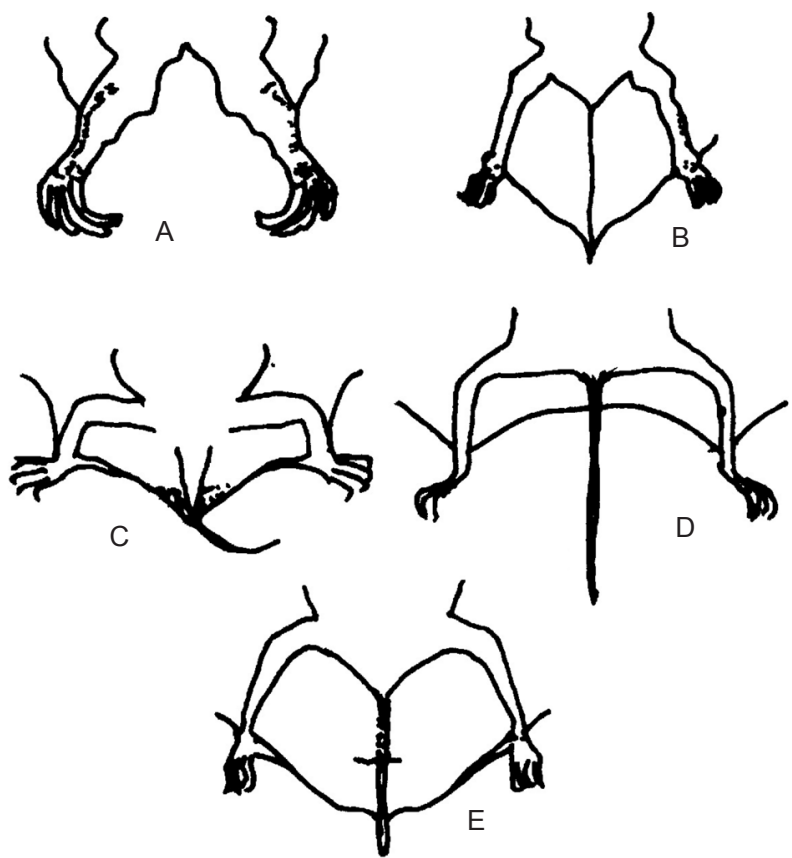

Figure 8. View of interfemoral membrane and tail in different families of bats

[A - Pteropodidae; B - Rhinolophidae, Hipposideridae, Vespertilionidae, Miniopteridae; C - Molossidae; D Rhinopomatidae; E - Emballonuridae]

dermal ridge). Ears with simple tragus (Fig. 7B) and joined over the forehead by thin membrane. The second and the third digits of each wing have two distinct bony phalanges. Tail very long, and is only partly enclosed by a small interfemoral membrane (Fig. 8D). Three species belonging to a single genus is reported from South Asia.

Brief description of the genus of the family Rhinopomatidae present in South Asia:

Rhinopoma E. Geoffroy, 1818 - Small to mediumsized bats (FA - 46.0-74.0 mm) with long tail (49.0-78.0 $\mathrm{mm}$ ). Tail mostly projecting free from the interfemoral membrane. One pair of upper and two pairs of lower incisors present. Other characters as outlined above. Three species - R. microphyllum (Brünnich, 1782), $R$. hardwickii Gray, 1837 and R. muscatellum Thomas, 1903 - occur in South Asia. Diagnostic morphological characters of the genus are provided in Table 4 and those of the species belonging to it in Table 4.1.

\section{Family Emballonuridae}

Includes about 51 species of insectivorous bats with wide distribution in Americas, Europe, Africa, Asia, Australia and Oceania (Mickleburgh et al. 2002; Simmons 2005). They have strong muzzle, and lack noseleaf. Ears with simple tragus. The basal part of the tail is enclosed loosely in the interfemoral membrane and the tip pierces the upper surface of the membrane and lies free on the dorsal side (Fig. 8E). Wings long and narrow and the second digit of each lack phalanges. Males usually have well-developed glands. Six species belonging to two genera are reported from South Asia.

Brief descriptions of the genera of the family Emballonuridae present in South Asia:

Taphozous E. Geoffroy, 1818 - Small to mediumsized bats (FA - 55.6-88.0 mm) with relatively medium sized and stout tail (20.0-46.0 mm). In some the chin is either naked or haired, and gular sac and/or glands on throat present or lacking. Some species have radiometacarpal pouch on the wing. Muzzle simple, lacks noseleaf, and nostrils open forward. Rostrum moderately elongated. One pair of upper and two pairs of lower incisors present. Five species - T. perforatus E. Geoffroy, 1818, T. longimanus Hardwicke, 1825, T. nudiventris Cretzschmar, 1830-31, T. melanopogon Temminck, 1841 and T. theobaldi Dobson, 1872 - occur in South Asia. Diagnostic morphological characters of the genus are provided in Table 4 and those of the species belonging to it in Table 4.2.

Saccolaimus Lesson, 1842 - Medium-sized bats (FA - 63.0-68.0 $\mathrm{mm}$ ) with relatively medium sized and stout tail $(21.0-35.0 \mathrm{~mm})$. The chin is covered with short hairs. Gular sac on throat well-developed in males and less developed in females. Radio-metacarpal pouch absent. Muzzle simple, lacks noseleaf, and nostrils open forward. Rostrum moderately elongated. One pair of upper and two pairs of lower incisors present. One species - S. saccolaimus (Temminck, 1838) - occurs in South Asia. Diagnostic morphological characters of the genus are provided in Table 4 and those of the species belonging to it in Table 4.2.

\section{Family Megadermatidae}

Includes five species of insectivorous and carnivorous bats with distribution restricted to Africa, Asia and Australia (Mickleburgh et al. 2002; Simmons 2005). Ears are large and oval, joined over the forehead by a membrane. Tragus is distinctly bifid (Fig. 7C). They have strong muzzle and noseleaf is simple and erect. On each wing the second digit possess one phalanx and the third digit possess two phalanges. Tail absent. Two species belonging to one genus is reported from South Asia.

Brief description of the genus of the family Megadermatidae present in South Asia:

Megaderma E. Geoffroy, 1810 - Small to mediumsized bats (FA - 54.0-71.5 mm) without a tail. Upper incisors totally lacking and two pairs of lower incisors present. Other characters as outlined above. Two species - M. spasma Linnaeus, 1758 and M. lyra E. Geoffroy, 1810 - occur in South Asia. Diagnostic morphological characters of the genus are provided in Table 4 and those of the species belonging to it in Table 4.3.

\section{Family Rhinolophidae}

Includes about 77 species of insectivorous bats with 
wide distribution in Europe, Africa, Asia and Australia (Mickleburgh et al. 2002; Simmons 2005). They have short muzzle and complex noseleaf that essentially bears an erect posterior lancet, lower horizontal horseshoe surrounding the nostrils and a perpendicular median sella (Fig. 9A). Ears pointed with well-developed antitragus (Fig. 7D). Tragus absent. The tail (13.0-55.0 $\mathrm{mm}$ ) is enclosed in the interfemoral membrane (Fig. 8B). Twenty species belonging to the single genus is reported from South Asia.

Brief description of the genus of the family Rhinolophidae present in South Asia:

Rhinolophus Lacépède, 1799 - Small to mediumsized bats (FA - 33.4-80.5 mm) with relatively medium sized tail (13.0-55.0 mm). One pair of upper and two pairs lower incisors present. Other characters as outlined above. Twenty species $-R$. ferrumequinum (Schreber, 1774), R. hipposideros (Bechstein, 1800), $R$. affinis Horsfield, 1823, R. pusillus Temminck, 1834, $R$. trifoliatus Temminck, 1834, R. luctus Temminck, 1835, $R$. rouxii Temminck, 1835, $R$. lepidus Blyth, 1844, $R$. macrotis Blyth, 1844, $1844 R$. mitratus Blyth, 1844, $R$. subbadius Blyth, 1844, R. pearsonii Horsfield, 1851, $R$. blasii Peters, 1867, R. yunanensis Dobson, 1872, $R$. mehelyi Matschie, 1902, R. beddomei Andersen, 1905, R. sinicus Andersen, 1905, R. cognatus Andersen 1906, $R$. bocharicus Kastchenko and Akimov, 1917 and $R$. shortridgei K. Andersen, 1918 - occur in South Asia. Diagnostic morphological characters of the genus are provided in Table 4 and those of the species belonging to it in Table 4.4 .

\section{Family Hipposideridae}

Includes about 81 species of insectivorous bats with wide distribution in Africa, Asia, Australia and Oceania (Mickleburgh et al. 2002; Simmons 2005). They have short muzzle and complex noseleaf that bears a horizontal horseshoe surrounding the nostrils, often thrown into skin folds and associated leaflets (Fig. 9B). Intermediate leaf may or may not be clearly differentiated. Posterior leaf simple to complex. Sella and connecting process absent. The tail is well-developed and enclosed in the interfemoral membrane (Fig. 8B). Other characters vary at the generic level. Fifteen species belonging to four genera are reported from South Asia.

Brief descriptions of the genera of the family Hipposideridae present in South Asia:

Hipposideros Gray, 1831 - Small to medium-sized leaf-nosed bats (FA - 33.0-99.0 mm) with a mediumsized tail (20.0-64.0 mm). Noseleaf with anterior leaf with or without median emargination, an intermediate leaf and a posterior leaf (Fig. 8). Supplementary leaflets may be absent or present, if present may vary from 1 to 4 and in some species the last being much reduced. Ears pointed with large antitragus. Tragus absent. The interfemoral membrane is broad and completely encloses the tail except the extreme tip. One pair of upper incisors and two pairs of lower incisors are present. Twelve species - H. speoris (Schneider, 1800), H. diadema (Geoffroy, E., 1813), H. larvatus (Horsfield, 1823), H. armiger (Hodgson, 1835), H. fulvus Gray, 1838, H. galeritus Cantor, 1846, $H$. ater Templeton, 1848, $H$. lankadiva Kelaart, 1850, $H$. cineraceus Blyth, 1853, H. pomona Andersen, 1908, $H$. durgadasi Khajuria, 1970 and $H$. hypophyllus Kock \& Bhat, 1994 - occur in South Asia. Diagnostic morphological characters of the genus are provided in Table 5 and those of the species belonging to it in Table 5.1.

Triaenops Dobson, 1871 - Medium-sized leaf-nosed bats (FA - 48.3-54.0 $\mathrm{mm}$ ) with a long tail (31.0-39.0 $\mathrm{mm}$ ). Muzzle elongated and broad. Noseleaf with anterior leaf with a deep median emargination, and internarial septum greatly expanded. Intermediate and posterior leaves undifferentiated, and upper border bears three vertical pointed processes. Narial lappets present. A single pair of supplementary leaflets present. Ears small. Tragus absent. The interfemoral membrane is broad and completely encloses the tail except the extreme tip. A bony spicule at the base of the terminal phalanx of the third finger is characteristic. One pair of upper and two pairs of lower incisors are present. One species - T. persicus Dobson, 1871 - occurs in South Asia. Diagnostic morphological characters of the genus are provided in Table 5 and those of the species belonging to it in Table 5.2 .

Asellia Gray, 1838 - Medium-sized leaf-nosed bats (FA - 50.1-52.3 mm) with a moderately small tail (25.0$28.0 \mathrm{~mm}$ ). Muzzle elongated and narrow. Noseleaf with simple anterior leaf lacking any emargination, and internarial septum not expanded. Intermediate leaf is smooth and slightly protuberant. Posterior leaf divided into four shallow cells with three ill-defined septa. The upper margin has three vertical processes of which the central one is pointed while those on the sides are blunt. Narial lappets little developed. Two pairs of supplementary leaflets present. The interfemoral membrane is broad and completely encloses the tail except the extreme tip (ca. 3-5 mm). One pair of upper and two pairs of lower incisors are present. One species - A. tridens Geoffroy, E., 1813 - occurs in South Asia. Diagnostic morphological characters of the genus are provided in Table 5 and those of the species belonging to it in Table 5.2 .

Coelops Blyth, 1848 - Small-sized leaf-nosed bats (FA - 37.8-42.0 mm) with a rudimentary tail $(<2.0 \mathrm{~mm})$. Noseleaf distinct with anterior leaf - distinctly divided into two by deep emargination and also bearing two elongated narrow supplementary lappets projecting beyond the muzzle. Intermediate leaf has moderately developed median process. Posterior leaf has a single cell and a median process. Noseleaf is covered with hairs. Ears 


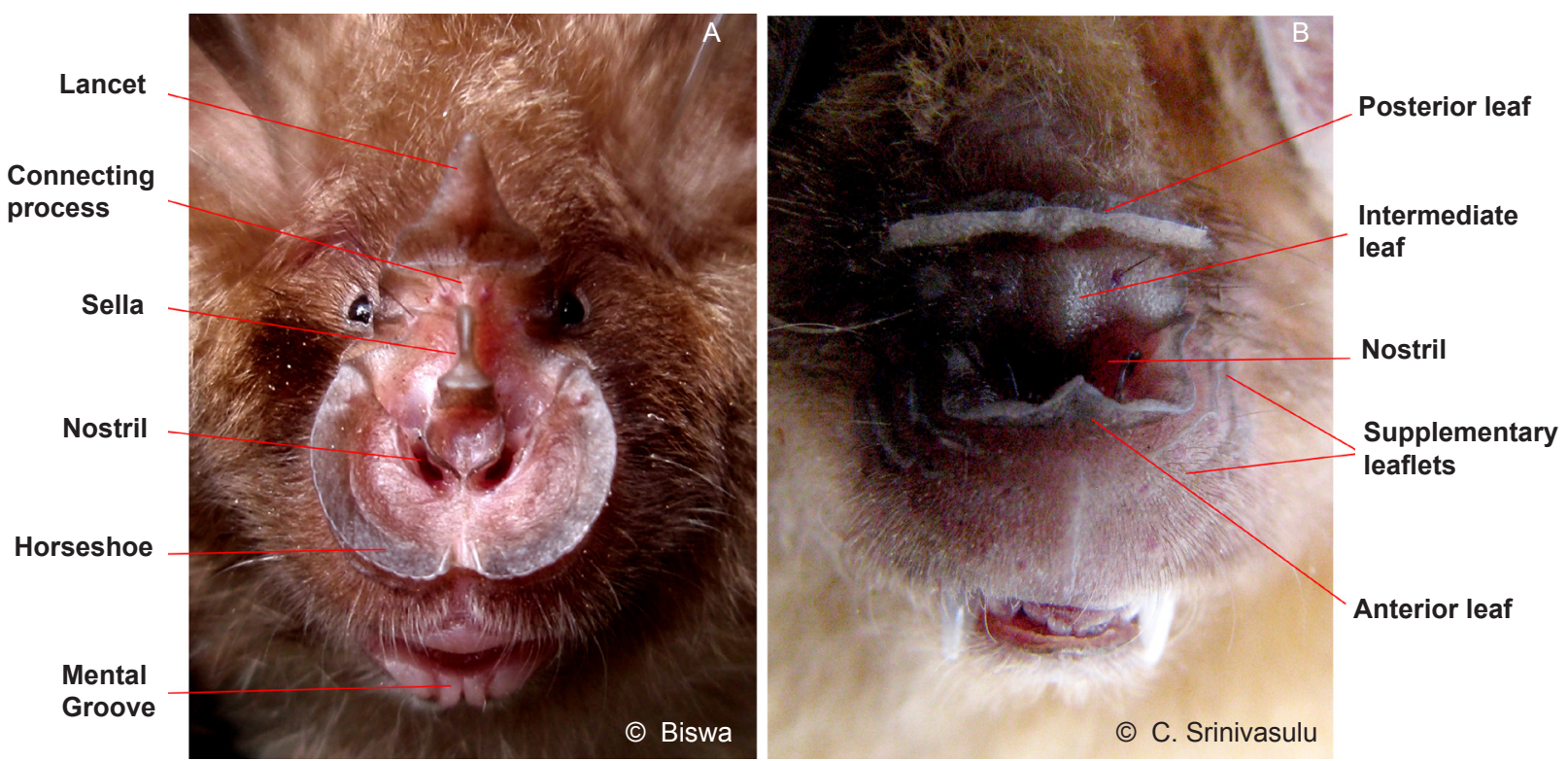

Figure 9. Frontal view of noseleaf of a Rhinolophid $[A]$ and a Hipposiderid $[B]$ bats

broad and have large antitragal lobe. The interfemoral membrane is narrow and poorly developed. One pair of upper and two pairs of lower incisors are present. One species - C. frithii Blyth, 1848 - occurs in South Asia. Diagnostic morphological characters of the genus are provided in Table 5 and those of the species belonging to it in Table 5.2.

\section{Family Molossidae}

Includes about 100 species of insectivorous bats with wide distribution in Americas, Europe, Africa, Asia, Australia and Oceania (Mickleburgh et al. 2002; Simmons 2005). Lacks noseleaf. Tail stout and conspicuously projecting out of a narrow interfemoral membrane (Fig. $8 C$ ). Ears variable, usually fleshy could either be free or joined by membrane over the head. Tragus is rudimentary, while the antitragus is rudimentary to large. The upper lip often wrinkled. Four species belonging to three genera are reported from South Asia.

Brief descriptions of the genera of the family Molossidae present in South Asia:

Tadarida Rafinesque, 1814 - Medium-sized freetailed bats (FA - 43.1-63.9 mm) with a medium-sized tail (30.0-54.8 mm). Ear, tail and other characters as outlined above. In some species ears are not joined over the forehead, while in some they are joined. Normally one pair of upper and two pairs of lower incisors are present, but one species has three pairs of lower incisors. Two species - T. teniotis (Rafinesque, 1814) and T. aegyptiaca (E. Geoffroy, 1818) - occur in South Asia. Diagnostic morphological characters of the genus are provided in Table 6 and those of the species belonging to it in Table
6.1.

Chaerephon Dobson, 1874 - Moderate-sized freetailed bats (FA - 43.1-50.5 mm) with a relatively long tail (30.0-44.0 mm). Ears large and connected by a membrane over the forehead. Tragus quadrate and minute, and antitragus half oval, separated posteriorly by a deep notch. One pair of upper and two pairs of lower incisors are present. One species $-C$. plicatus (Buchanan, 1800) - occurs in South Asia. Diagnostic morphological characters of the genus are provided in Table 6 and those of the species belonging to it in Table 6.1 .

Otomops Thomas, 1913 - Moderately large-sized free-tailed bats (FA - 63.0-67.0 mm) with a relatively long tail (41.0-49.0 mm). Ears large and connected by a membrane over the forehead. Tragus triangular and minute, and antitragus absent. One pair of upper and two to three pairs of lower incisors are present. One species - O. wroughtoni (Thomas, 1913) - occurs in South Asia. Diagnostic morphological characters of the genus are provided in Table 6 and those of the species belonging to it in Table 6.1.

\section{Family Vespertilionidae}

Includes more than 400 species of insectivorous bats with wide distribution in Americas, Europe, Africa, Asia, Australia and Oceania (Mickleburgh et al. 2002; Simmons 2005). Muzzle simple and lacks the noseleaf. Ears separate from each other, however in few species they are joined over the forehead. Tragus is welldeveloped (Fig. 7E, F, G, H). The shape of antitragus can also be diagnostic. There is a considerable variation in the number of teeth among the genera. The long tail 
is completely enclosed in the interfemoral membrane or the extreme tip protrudes out (Fig. 8B). Sixty-three species belonging to twenty three genera are reported from South Asia.

Brief descriptions of the genera of the family Vespertilionidae present in South Asia:

Murina Gray, 1842 - Small to medium-sized bats (FA - 27.7-40.9 mm) with a moderately long tail (27.0-41.0 $\mathrm{mm})$. The interfemoral membrane encloses the entire but the extreme tip of the tail. Ears short and broad with long and narrow tragus. Projecting tubular nostrils characteristic. Wings attached either to the base of the claw of the first toe or to the base of the toe. Two pairs of upper incisors and three pairs of lower incisors are present. Two pairs each of upper and lower premolars are present. Five species - $M$. leucogaster MilneEdwards, 1872, M. aurata Milne-Edwards, 1872, M. cyclotis Dobson, 1872, M. huttoni (Peters, 1872) and $M$. tubinaris (Scully, 1881) - occur in South Asia. Diagnostic morphological characters of the genus are provided in Table 7 and those of the species belonging to it in Table 7.1.

Harpiola Thomas, 1915 - Medium-sized bats (FA 32.4-32.8 $\mathrm{mm}$ ) with a moderately long tail $(\sim 27.5 \mathrm{~mm})$. The interfemoral membrane encloses the entire but the extreme tip of the tail. Ears short and broad with triangular terminal half. Tragus long and narrow, acutely pointed and curved outwards. Projecting tubular nostrils characteristic. Wings attached to the base of the first toe. Two pairs of upper incisors and three pairs of lower incisors are present. Two pairs each of upper and lower premolars are present. One species - H. grisea (Peters, 1872) - occurs in South Asia. Diagnostic morphological characters of the genus are provided in Table 7 and those of the species belonging to it in Table 7.1.

Harpiocephalus Gray, 1842 - Small to mediumsized bats (FA - 44.1-50.1 mm) with a moderately long tail (40.0-50.0 mm). The interfemoral membrane encloses the entire but the extreme tip of the tail. Muzzle short. Ears moderate with long tragus. Projecting tubular nostrils characteristic. Two pairs of upper incisors and three pairs of lower incisors are present. Two pairs each of upper and lower premolars are present. One species - H. harpia (Temminck, 1840) - occurs in South Asia. Diagnostic morphological characters of the genus are provided in Table 7 and that of the species belonging to it in Table 7.1.

Kerivoula Gray, 1842 - Small-sized bats (FA - 31.5$42.0 \mathrm{~mm}$ ) with a long tail $(35.0-55.0 \mathrm{~mm})$. The interfemoral membrane encloses the entire but the extreme tip of the tail. Ears moderately long and funnel shaped with long and slender tragus. Muzzle simple. Two pairs of upper incisors and three pairs of lower incisors are present. Three pairs each of upper and lower premolars are present. Three species - K. picta (Pallas, 1767),
K. hardwickii (Horsfield, 1825) and K. lenis Thomas, 1916 - occur in South Asia. Diagnostic morphological characters of the genus are provided in Table 7 and those of the species belonging to it in Table 7.2.

Myotis Kaup, 1829 - Small to medium-sized bats (FA - 30.0-58.3 mm) with a long tail (25.0-68.0 mm). The interfemoral membrane encloses the entire but the extreme tip of the tail. Ears usually tall and slender, and occasionally large. Tragus well-developed and spear shaped (Fig. 7E). Two pairs of upper and three pairs of lower incisors are present. Some species have three pairs each of upper and lower premolars, while in some species consistently only two pairs of both upper and lower premolars present. Fourteen species $-M$. emarginatus (E. Geoffroy, 1806), M. laniger (Peters, 1871), M. formosus (Hodgson, 1835), M. hasseltii (Temminck, 1840), M. horsfieldii (Temminck, 1840), $M$. muricola (Gray, 1846), M. siligorensis (Horsfield, 1855), $M$. blythii (Tomes, 1857), M. annectans (Dobson, 1871), $M$. nipalensis (Dobson, 1871), M. longipes (Dobson, 1873), M. montivagus (Dobson, 1874), $M$. sicarius Thomas, 1915 and M. csorbai Topal, 1997 - occur in South Asia. Diagnostic morphological characters of the genus are provided in Table 7 and those of the species belonging to it in Table 7.3.

Plecotus Geoffroy, E., 1818 - Small-sized bats (FA - 36.5-45.1 mm) with a long tail (48.0-54.0 mm). The interfemoral membrane encloses entire but the extreme tip of the tail. Ears usually large and joined over the forehead. Tragus well-developed and antitragus absent (Fig. 7F). Nostrils open upwards with their orifices extended backwards by a fissure. Two pairs of upper and three pairs of lower incisors are present. Two pairs of upper and three pairs of lower premolars are present. Three species $-P$. homochrous Hodgson, 1847, $P$. wardi Thomas, 1911 and P. strelkovi Spitzenberger, 2008 occur in South Asia. Diagnostic morphological characters of the genus are provided in Table 7 and those of the species belonging to it in Table 7.4.

Barbastella Gray, 1821 - Small-sized bats (FA 38.7-42.1 mm) with a moderately long tail (40.0-47.0 $\mathrm{mm}$ ). The interfemoral membrane encloses the entire but the extreme tip of the tail. Ears broad and not greatly elongated, forward facing and joined over the forehead. Tragus triangular and antitragus undefined. Nostrils open upwards and outwards. Two pairs of upper and three pairs of lower incisors are present. Two pairs each of upper and lower premolars are present. One species - B. leucomelas (Cretzschmar, 1826) - occurs in South Asia. Diagnostic morphological characters of the genus are provided in Table 7 and those of the species belonging to it in Table 7.4.

Otonycteris Peters, 1859 - Large-sized bats (FA - 64.7-65.6 mm) with a moderately long tail (40.0-58.0 $\mathrm{mm})$. The interfemoral membrane encloses the entire 
but the extreme tip of the tail. Ears elongated. Tragus large and antitragus small with a shallow notch. Nostrils are crescent shaped. One pair of upper and three pairs of lower incisors are present. One pair of upper and two pairs of lower premolars are present. One species - O. hemprichii Peters, 1859 - occurs in South Asia. Diagnostic morphological characters of the genus are provided in Table 7 and those of the species belonging to it in Table 7.4 .

Scotoecus Thomas, 1901 - Small-sized bats (FA 34.1-37.3 $\mathrm{mm}$ ) with a moderately long tail (34.0-41.0 mm). The interfemoral membrane encloses the entire but the extreme tip of the tail. Ears moderate with long and narrow tragus. Muzzle broadened and flattened. One pair of upper and three pairs of lower incisors are present. One pair of upper and two pairs of lower premolars are present. One species - S. pallidus Dobson, 1876-occurs in South Asia. Diagnostic morphological characters of the genus are provided in Table 7 and those of the species belonging to it in Table 7.5.

Scotomanes Dobson, 1875 - Medium to large-sized bats (FA - 56.1-61.2 mm) with a moderately long tail (52.0-66.0 mm). The interfemoral membrane encloses the entire but the extreme tip of the tail. Ears elongated with broad tragus. Antitragus undefined. Nostrils simple and face slightly outward. One pair of upper and three pairs of lower incisors are present. One pair of upper and two pairs of lower premolars are present. One species - S. ornatus (Blyth, 1851) - occurs in South Asia. Diagnostic morphological characters of the genus are provided in Table 7 and those of the species belonging to it in Table 7.5.

Scotophilus Leach, 1821 - Medium to large-sized bats (FA - 44.0-65.8 $\mathrm{mm}$ ) with a moderately long tail $(40.0-71.0 \mathrm{~mm})$. The interfemoral membrane encloses the entire but the extreme tip of the tail. Ears relatively small with crescent shaped tragus. Antitragus welldeveloped. Nostrils simple and face slightly outward. One pair of upper and three pairs of lower incisors are present. One pair of upper and two pairs of lower premolars are present. Two species $-S$. kuhlii Leach, 1821 and S. heathi Horsfield, 1831 - occur in South Asia. Diagnostic morphological characters of the genus are provided in Table 7 and those of the species belonging to it in Table 7.5.

Arielulus Hill \& Harrison, 1987 - Large-sized bats (FA $-41.8-43.6 \mathrm{~mm}$ ) with a moderately long tail ( 40.0 $\mathrm{mm})$. The interfemoral membrane encloses the entire but the extreme tip of the tail. Ears short and broad, tragus welldeveloped and broadest in the middle. Usually two pairs of upper and three pairs of lower incisors; and two pairs each of upper and lower premolars are present. One species - A. circumdatus (Temminck, 1840) - occurs in South Asia. Diagnostic morphological characters of the genus are provided in Table 7 and those of the species belonging to it in Table 7.6.

Hesperoptenus Peters, 1869 - Medium to largesized bats (FA $-50.0-60.4 \mathrm{~mm}$ ) with a moderately long tail (44.0-63.0 mm). The interfemoral membrane encloses the entire but the extreme tip of the tail. Ears large, thick and fleshy with large crescent shaped tragus. Antitragus well-developed. Muzzle broadened. Two pairs of upper incisors and three pairs of lower incisors are present. One pair of upper premolars and two pairs of lower premolars are present. One species $-H$. tickelli (Blyth, 1851) - occurs in South Asia. Diagnostic morphological characters of the genus are provided in Table 7 and those of the species belonging to it in Table 7.6.

Eptesicus Rafinesque, 1820 - Small to mediumsized bats (FA - 35.4-55.1 mm) with a moderately long tail (38.0-58.0 mm). The interfemoral membrane encloses the entire but the extreme tip of the tail. Ears large with short and blunt tragus. Antitragus not well defined. Two pairs of upper and three pairs of lower incisors are present. One pair of upper and two pairs of lower premolars are present. Seven species - E. serotinus (Schreber, 1774), E. bottae (Peters, 1869), E. pachyotis (Dobson, 1871), E. nasutus (Dobson, 1877), E. dimissus Thomas, 1916, E. gobiensis Bobrinskii, 1926 and E. tatei Ellerman \& Morrison-Scott, 1951 - occur in South Asia. Diagnostic morphological characters of the genus are provided in Table 7 and those of the species belonging to it in Table 7.6.

Nyctalus Bowdich, 1825 - Medium-sized bats (FA - 42.1-57.8 mm) with a moderately long tail (31.0-55.0 $\mathrm{mm})$. The interfemoral membrane encloses the entire but the extreme tip of the tail. Ears relatively short with a club shaped tragus. Two pairs of upper and three pairs of lower incisors are present. Two pairs each of upper and lower premolars are present. Three species $-N$. noctula (Schreber, 1774); N. leisleri (Kuhl, 1817); and N. montanus (Barrett-Hamilton, 1906) - occur in South Asia. Diagnostic morphological characters of the genus are provided in Table 7 and those of the species belonging to it in Table 7.7.

Pipistrellus Kaup, 1829 - Small to medium-sized bats (FA - 25.0-42.6 mm) with a moderately long tail (20.0-49.0 mm). The interfemoral membrane encloses the entire but the extreme tip of the tail. Ears short and broad, tragus well-developed (Fig. 7G). Antitragus is not well defined. On the muzzle, pararhinal glands and internarial groove are distinct. Usually two pairs of upper and three pairs of lower incisors; and two pairs each of upper and lower premolars are present. Some species have reduction in dentition. Eight species $-P$. pipistrellus (Schreber, 1774), P. kuhlii (Kuhl, 1817), P. coromandra (Gray, 1838), P. javanicus (Gray, 1838), $P$. abramus (Temminck, 1840), P. tenuis (Temminck, 1840), $P$. ceylonicus (Kelaart, 1852) and $P$. paterculus Thomas, 1915 - occur in South Asia. Diagnostic morphological 
characters of the genus are provided in Table 7 and those of the species belonging to it in Table 7.7.

Scotozous Dobson, 1875 - Medium-sized bats (FA - 32.7-36.0 mm) with a moderately long tail (27.0-41.0 $\mathrm{mm})$. The interfemoral membrane encloses the entire but the extreme tip of the tail. Ears short and broad, tragus well-developed with small triangular lobe near the base of the outer margin. Penis enlarged. One pair of upper (second upper usually absent, when present very minute) and three pairs of lower incisors; and two pairs each of upper and lower premolars are present. One species - S. dormeri Dobson, 1875 - occurs in South Asia. Diagnostic morphological characters of the genus are provided in Table 7 and those of the species belonging to it in Table 7.7.

Tylonycteris Peters, 1872 - Small-sized bats (FA - 26.1-29.0 mm) with a long tail (26.0-33.0 mm). The interfemoral membrane encloses the entire but the extreme tip of the tail. Ears triangular, with short and broad tragus. Head characteristically broadened and flattened. Fleshy pads on the ball of thumb and sole of the foot characteristic. Two pairs of upper and three pairs of lower incisors are present. One pair of upper and two pairs of lower premolars are present. Two species T. pachypus (Temminck, 1840) and T. robustula Thomas, 1915 - occur in South Asia. Diagnostic morphological characters of the genus are provided in Table 7 and those of the species belonging to it in Table 7.8.

la Thomas, 1902 - Large-sized bats (FA - 70.9$77.3 \mathrm{~mm})$ with a moderately long tail $(\sim 65.0 \mathrm{~mm})$. The interfemoral membrane encloses the entire but the extreme tip of the tail $(\sim 6.0 \mathrm{~mm})$. Ears broad with moderately long tragus. Nostrils simple and face slightly outward. Two pairs of upper and three pairs of lower incisors are present. Two pairs each of upper and lower premolars are present. One species - I. io Thomas, 1902 - occurs in South Asia. Diagnostic morphological characters of the genus are provided in Table 7 and those of the species belonging to it in Table 7.8.

Falsistrellus Throughton, 1943 - Medium-sized bats (FA - 38.4-41.4 mm) with a moderately long tail (30.0-41.0 mm). The interfemoral membrane encloses the entire but the extreme tip of the tail. Ears squarish with broadly rounded tips, tragus well-developed with a small triangular lobe near the base of the outer margin. On the muzzle, pararhinal glands and internarial groove are distinct. Two pairs of upper and three pairs of lower incisors; and two pairs each of upper and lower premolars are present. One species - F. affinis (Dobson, 1871) - occurs in South Asia. Diagnostic morphological characters of the genus are provided in Table 7 and those of the species belonging to it in Table 7.8.

Philetor Thomas, 1902 - Small-sized bats (FA 31.7-35.7 $\mathrm{mm}$ ) with a moderately long tail (27.1-32.2 $\mathrm{mm})$. The interfemoral membrane encloses the entire but the extreme tip of the tail. Ears short with broad, short fleshy and thick tragus. Two pairs of upper incisors and three pairs of lower incisors are present. One pair of upper premolars and two pairs of lower premolars are present. One species $-P$. brachypterus (Temminck, 1840) - occurs in South Asia. Diagnostic morphological characters of the genus are provided in Table 7 and those of the species belonging to it in Table 7.8.

Vespertilio Linnaeus, 1758 - Medium-sized bats (FA - 42.0-45.5 mm) with a moderately long tail (40.0$48.0 \mathrm{~mm}$ ). The interfemoral membrane encloses the entire but the extreme tip of the tail. Ears relatively small and broad, with small, short, blunt and rounded tragus. Antitragus well defined. Nostrils simple and face slightly outward. Two pairs of upper and three pairs of lower incisors are present. One pair of upper and two pairs of lower premolars are present. One species $-V$. murinus Linnaeus, 1758 - occurs in South Asia. Diagnostic morphological characters of the genus are provided in Table 7 and those of the species belonging to it in Table 7.8.

Hypsugo Kolenati, 1856 - Medium-sized bats (FA - 32.1-38.0 mm) with a moderately long tail (30.0-49.0 $\mathrm{mm}$ ). The interfemoral membrane encloses the entire but the extreme tip of the tail. Ears short and broad, tragus well-developed. Antitragus is not well defined. Usually two pairs of upper and three pairs of lower incisors; and one pair of upper and two pairs lower premolars are present. Two species $-H$. savii (Bonaparte, 1873) and $H$. cadornae (Thomas, 1916) - occur in South Asia. Diagnostic morphological characters of the genus are provided in Table 7 and those of the species belonging to it in Table 7.8 .

\section{Family Miniopteridae}

Includes about 19 species of insectivorous bats with wide distribution in Americas, Europe, Africa, Asia, Australia and Oceania (Mickleburgh et al. 2002; Simmons 2005). Muzzle simple and lacks the noseleaf. Ears separate from each other. Tragus is welldeveloped. The long tail is completely enclosed in the interfemoral membrane or the extreme tip protrudes out. Characteristically posses greatly elongated third digit whose second phalanx is markedly longer than that of the first, owing to which the distal end of the wing bends over the body while at rest. Three species belonging to one genus are reported from South Asia.

Miniopterus Bonaparte, 1837 - Medium-sized bats (FA - 39.6-49.6 mm) with a long tail (39.6-61.0 mm). The interfemoral membrane encloses the entire but the extreme tip of the tail. Ears small with tall, slender and slightly forwardly curved tragus (Fig. 7H). Muzzle short. Two pairs of upper incisors and three pairs of lower incisors are present. Two pairs of upper premolars and three pairs of lower premolars are present. Three 
species - M. fuliginosus (Hodgson, 1835), M. pusillus Dobson, 1876 and M. magnater Sanborn, 1931 - occur in South Asia. Diagnostic morphological characters of the genus are provided in Table 8 and those of the species belonging to it in Table 8.1.

\section{REFERENCES}

Bates, P.J.J. \& D.L. Harrison (1997). Bats of the Indian Subcontinent. Harrison Zoological Museum Publications, Sevenoaks, UK, $258 \mathrm{pp}$.

Blanford, W.T. (1888-91). The Fauna of British India, Mammalia. Taylor \& Francis, London, 617pp. (in two parts).

Corbet, G.B. \& J.E. Hill (1992). The Mammals of the Indomalayan Region. British Museum (Natural History)/ Oxford University Press, London, 488pp.

Eick, G.N., D.S. Jacobs \& C.A. Matthee (2005). A nuclear DNA phylogenetic perspective on the evolution of echolocation and historical biogeography of extant bats (Chiroptera). Molecular Biology and Evolution 22(9): 1869-1886

Gunnel, G.F. \& N.B. Simmons (2005). Fossil evidence and the origin of bats. Journal of Mammalian Evolution 12: 209246

Hutson, A.M., S.P. Mickleburgh \& P.A. Racey (compilers) (2001). Microchiropteran Bats: Global Status, Survey and Conservation Action Plan. International Union for Conservation of Nature and Natural Resources, Chiroptera Specialist Group (IUCN/SSC). Gland, Switzerland, 258pp.

Jones, G. \& E.C. Teeling (2006). The evolution of echolocation in bats. Trends in Ecology and Evolution 21(3): 149-156.

Koopman, K.F. (1993). Order Chiroptera, pp.137-241. In: Wilson, D.E. \& D.M. Reeder (eds.). Mammal Species of the World, 2nd Edition. Smithsonian Institution Press, Washington, 1206pp.

Mickleburgh, S.P., A.M. Hutson \& P.A. Racey (compilers) (1992). Old World Fruit Bats. An Action Plan for their Conservation. International Union for Conservation of Nature and Natural Resources, Chiroptera Specialist Group (IUCN/SSC), Gland, Switzerland, 252pp.

Mickleburgh, S.P., A.M. Hutson \& P.A. Racey (2002). A review of the global conservation status of bats. Oryx 36(1): 18-34.

Molur, S., G. Marimuthu, C. Srinivasulu, S. Mistry, A.M. Hutson, P.J.J. Bates, S. Walker, K.P. Priya \& A.R.B. Priya (eds.) (2002). Status of South Asian Chiroptera: Conservation Assessment and Management Plan (C.A.M.P.) Workshop Report. Zoo Outreach Organisation, Conservation Breeding Specialist Group South Asia, and Wildlife Information \& Liaison Development Society, Coimbatore, India, viii+154pp.+CD.

Simmons, N.B. (2005). Order Chiroptera, pp.312-529. In: D.E. Wilson and D.M. Reeder (eds.), Mammal Species of the World, 3rd Edition, Volume 1. The John Hopkins University Press, Baltimore, MD, USA. 2142 pp.

Simmons, N.B.\& J.H.Geisler(1998). Phylogeneticrelationships of Icaronycteris, Archaeonycteris, Hassianycteris and Palaeochiropteryx to extant bat lineages with comments on the evolution of echolocation and foraging strategies in Microchiroptera. Bulletin of the American Museum of
Natural History 235: 1-182.

Springer, M.S., E.C. Teeling, O. Madsen, M.J. Stanhope \& W.W. De Jong (2001). Integrated fossil and molecular data reconstruct bat echolocation. Proceedings of the National Academy of Sciences (USA) 98: 6241-6246.

Srinivasulu, C. \& B. Srinivasulu (2001). Bats of the Indian subcontinent. Current Science 80(11): 1378-1380.

Srinivasulu, C., B. Srinivasulu \& Y.P. Sinha (in review). Bats (Mammalia: Chiroptera) of South Asia: Biogeography, Diversity, Taxonomy and Distribution. Journal of Threatened Taxa.

Teeling, E.C., M.S. Springer, O. Madsen, P. Bates, S.J. O'Brien \& W.J. Murphy (2005). A molecular phylogeny for bats illuminates biogeography and the fossil record. Science 307: 580-584.

Appendix I. Some important literature consulted to prepare the key

Advani, R. (1982). Distribution and status of chiroptera species in Rajasthan, India. Saugertierkundliche Mitteilungen 30(1): 49-52.

Aellen, V. (1959). Contribution a 1etude de la faune d'Afghanistan. Chiropteres. Revue suisse Zoologie 66: 353386.

Agrawal, V.C. (1973). On a collection of bats from Goa. Records of the Zoological Survey of India 67: 261-280.

Agrawal, V.C. \& T.P. Bhattacharyya (1976). Report on a collection of mammals from Nagarjuna Sagar, Andhra Pradesh. Newsletter of the Zoological Survey of India 2(5): 212-216.

Agrawal, V.C. \& T.P. Bhattacharyya (1977). Report on a collection of mammals from Tripura. Records of the Zoological Survey of India 73(1-4): 135-157.

Agrawal, V.C. \& S. Chakraborty (1971). Notes on a collection of small mammals from Nepal, with the description of a new mouse-hare (Lagomorpha: Ochotonidae). Proceedings of the Zoological Society, Calcutta 24(1): 41-46.

Agrawal, V.C., P.K. Das, S. Chakraborty. R.K. Ghose, A.K. Mandal, T.K. Chakraborty, A.K. Poddar, J.P. Lal, T.P. Bhattacharyya \& M.K. Ghosh (1992). Mammalia. pp.27169. In: Director, ZSI (ed.). State Fauna Series 3: Fauna of West Bengal, Part 1. Zoological Survey of India, Calcutta.

Agrawal, V.C. \& Y.P. Sinha (1973). Studies on the bacula of some oriental bats. Anatomischer Anzeiger 133: 180-192.

Ahmed, S.K. \& K.Z. Husain (1982). Bats of Bangladesh. Journal Asiatic Society of Bangladesh (Science) 8: 89-99.

Allen, G.M. (1936). Two new races of Indian bats. Records Indian Museum 38: 343-346.

Allen, G.M. (1938). The Mammals of China and Mongolia. American Museum of Natural History, New York, 620pp.

Andersen, K. (1908). Twenty new forms of Pteropus. Annals and Magazine of Natural History 2: 361-370.

Andersen, K. (1910). Ten new fruit-bats of the genera Nyctimene, Cynopterus and Eonycteris. Annals and Magazine of Natural History 7: 641-643.

Andersen, K. (1911). Six new fruit-bats of the genera Macroglossus and Syconycteris. Annals and Magazine of Natural History 7: 641-643. 
Table 1. Classical and modern classification of bats

\begin{tabular}{|c|c|c|c|}
\hline Classical & \multicolumn{3}{|c|}{ Modern } \\
\hline Koopman 1993 & $\begin{array}{l}\text { Simmons \& Geisler } 1998 \\
\text { Gunnels \& Simmons } 2005\end{array}$ & $\begin{array}{l}\text { Springer et al. } 2001 \\
\text { Teeling et al. } 2005\end{array}$ & $\begin{array}{l}\text { Eick et al. } 2005 \\
\text { Jones \& Teeling } 2006\end{array}$ \\
\hline Order Chiroptera & Order Chiroptera & Order Chiroptera & Order Chiroptera \\
\hline Suborder Megachiroptera & Suborder Megachiroptera & Suborder Yinpterochiroptera & Suborder Yinpterochiroptera \\
\hline Family Pteropodidae & Family Pteropodidae & Superfamily Pteropodoidea & Superfamily Pteropodoidea \\
\hline Suborder Microchiroptera & Suborder Microchiroptera & Family Pteropodidae & Family Pteropodidae \\
\hline Family Rhinopomatidae & Superfamily Emballonuroidea & Superfamily Rhinolophoidea & Superfamily Rhinolophoidea \\
\hline Family Craseonycteridae & Family Emballonuridae & Family Rhinopomatidae & Family Rhinolophidae \\
\hline Family Nycteridae & Infraorder Yinochiroptera & Family Megadermatidae & Family Hipposideridae \\
\hline Family Megadermatidae & Superfamily Rhinopomatoidea & Family Rhinolophidae & Family Megadermatidae \\
\hline Family Rhinolophidae & Family Rhinopomatidae & Subfamily Rhinolophinae & Family Craseonycteridae \\
\hline Family Hipposideridae & Superfamily Rhinolophoidea & Subfamily Hipposiderinae & Family Rhinopomatidae \\
\hline Family Mormoopidae & Family Nycteridae & Suborder Yangochiroptera & Suborder Yangochiroptera \\
\hline Family Noctilionidae & Family Megadermatidae & Family Nycteridae incertae sedis & Family Nycteridae \\
\hline Family Phyllostomidae & Family Rhinolophidae & Superfamily Emballonuroidea & Superfamily Emballonuroidea \\
\hline Family Mormoopidae & Subfamily Hipposiderinae & Family Emballonuridae & Family Emballonuridae \\
\hline Family Noctilionidae & Subfamily Rhinolophinae & Superfamily Noctilionoidea & Superfamily Noctilionoidea \\
\hline Family Furipteridae & Infraorder Yangochiroptera & Family Noctilionidae & Family Phyllostomidae \\
\hline Family Thyropteridae & Superfamily Noctilionoidea & Family Phyllostomidae & Family Mormoopidae \\
\hline Family Natalidae & Family Noctilionidae & Superfamily Vespertilionoidea & Family Noctilionidae \\
\hline Family Mystacinidae & Family Phyllostomidae & Family Natalidae & Family Furipteridae \\
\hline Family Vespertilionidae & Superfamily Nataloidea & Family Vespertilionidae & Family Thyropteridae \\
\hline \multirow[t]{6}{*}{ Family Molossidae } & Family Natalidae & Family Molossidae & Family Mystacinidae \\
\hline & Superfamily Molossoidea & & Superfamily Vespertilionoidea \\
\hline & Family Antrozoidae & & Family Vespertilionidae \\
\hline & Family Molossidae & & Family Molossidae \\
\hline & Superfamily Vespertilionoidea & & Family Miniopteridae \\
\hline & Family Vespertilionidae & & Family Natalidae \\
\hline
\end{tabular}


Table 2. Checklist of bats of South Asia

\begin{tabular}{|c|}
\hline $\begin{array}{l}\text { Family Pteropodidae (Old World fruit bats) } \\
\text { [8 Genera, } 13 \text { Species] }\end{array}$ \\
\hline 1. Rousettus aegyptiacus (E. Geoffroy, 1810) \\
\hline 2. Rousettus leschenaultii (Desmarest, 1820) \\
\hline 3. Pteropus giganteus Brunnich, 1782 \\
\hline 4. Pteropus faunulus Miller, 1902 \\
\hline 5. Pteropus hypomelanus Temminck, 1853 \\
\hline 6. Pteropus melanotus Blyth, 1863 \\
\hline 7. Cynopterus sphinx (Vahl, 1797) \\
\hline 8. Cynopterus brachyotis (Muller, 1838) \\
\hline 9. Megaerops niphanae Yenbutra \& Felten, 1983 \\
\hline 10. Latidens salimalii Thonglongya, 1972 \\
\hline 11. Sphaerias blanfordi (Thomas, 1891) \\
\hline 12. Eonycteris spelaea (Dobson, 1871) \\
\hline 13. Macroglossus sobrinus K. Andersen, 1911 \\
\hline $\begin{array}{l}\text { Family Rhinopomatidae (Mouse-tailed bats) } \\
\text { [1 Genus, } 3 \text { Species] }\end{array}$ \\
\hline 14. Rhinopoma microphyllum (Brunnich, 1782) \\
\hline 15. Rhinopoma hardwickii Gray, 1831 \\
\hline 16. Rhinopoma muscatellum Thomas, 1903 \\
\hline $\begin{array}{l}\text { Family Emballonuridae (Sheath-tailed bats) } \\
\text { [2 Genera, } 6 \text { Species] }\end{array}$ \\
\hline 17. Taphozous longimanus Hardwicke, 1825 \\
\hline 18. Taphozous melanopogon Temminck 1841 \\
\hline 19. Taphozous perforatus E. Geoffroy, 1818 \\
\hline 20. Taphozous theobaldi Dobson, 1872 \\
\hline 21. Taphozous nudiventris Cretzschmar, 1830 \\
\hline 22. Saccolaimus saccolaimus (Temminck, 1838) \\
\hline $\begin{array}{l}\text { Family Megadermatidae } \\
\text { (False Vampire bats) } \\
\text { [1 Genus, } 2 \text { Species] }\end{array}$ \\
\hline 23. Megaderma lyra E. Geoffroy, 1810 \\
\hline 24. Megaderma spasma (Linnaeus, 1758) \\
\hline $\begin{array}{l}\text { Family Rhinolophidae (Horseshoe bats) } \\
\text { [1 Genus, } 20 \text { Species] }\end{array}$ \\
\hline 25. Rhinolophus mehelyi Matschie, 1901 \\
\hline 26. Rhinolophus ferrumequinum (Schreber, 1774) \\
\hline 27. Rhinolophus bocharicus Kastschenko and Akimov, 1917 \\
\hline 28. Rhinolophus affinis Horsfield, 1823 \\
\hline 29. Rhinolophus rouxii Temminck, 1835 \\
\hline 30. Rhinolophus sinicus Andersen, 1905 \\
\hline 31. Rhinolophus hipposideros (Bechstein, 1800) \\
\hline 32. Rhinolophus pusillus Temminck, 1834 \\
\hline 33. Rhinolophus subbadius Blyth, 1844 \\
\hline 34. Rhinolophus lepidus Blyth, 1844 \\
\hline 35. Rhinolophus shortridgei Andersen, 1918 \\
\hline 36. Rhinolophus cognatus K. Andersen, 1906 \\
\hline
\end{tabular}

\begin{tabular}{|c|}
\hline 37. Rhinolophus blasii Peters, 1867 \\
\hline 38. Rhinolophus macrotis Blyth, 1844 \\
\hline 39. Rhinolophus luctus Temminck, 1835 \\
\hline 40. Rhinolophus beddomei Andersen, 1905 \\
\hline 41. Rhinolophus trifoliatus Temminck, 1834 \\
\hline 42. Rhinolophus pearsonii Horsfield, 1851 \\
\hline 43. Rhinolophus yunanensis Dobson, 1872 \\
\hline 44. Rhinolophus mitratus Blyth, 1844 \\
\hline $\begin{array}{l}\text { Family Hipposideridae (Leaf-nosed bats) } \\
\text { [4 Genera, } 15 \text { Species] }\end{array}$ \\
\hline 45. Hipposideros ater Templeton, 1848 \\
\hline 46. Hipposideros cineraceus Blyth, 1853 \\
\hline 47. Hipposideros durgadasi Khajuria, 1970 \\
\hline 48. Hipposideros fulvus Gray, 1838 \\
\hline 49. Hipposideros pomona K. Andersen, 1918 \\
\hline 50. Hipposideros hypophyllus Kock \& Bhat, 1994 \\
\hline 51. Hipposideros galeritus Cantor, 1846 \\
\hline 52. Hipposideros speoris (Schneider, 1800) \\
\hline 53. Hipposideros larvatus (Horsfield, 1823) \\
\hline 54. Hipposideros armiger (Hodgson, 1835) \\
\hline 55. Hipposideros lankadiva Kelaart, 1850 \\
\hline 56. Hipposideros diadema (E. Geoffroy, 1813) \\
\hline 57. Triaenops persicus Dobson, 1871 \\
\hline 58. Asellia tridens E. Geoffroy, 1813 \\
\hline 59. Coelops frithi Blyth, 1848 \\
\hline $\begin{array}{l}\text { Family Molossidae (Free-tailed bats) } \\
\text { [3 Genera, } 4 \text { Species] }\end{array}$ \\
\hline 60. Tadarida teniotis (Rafinesque, 1814) \\
\hline 61. Tadarida aegyptiaca (E. Geoffroy, 1818) \\
\hline 62. Chaerephon plicatus (Buchanan, 1800) \\
\hline 63. Otomops wroughtoni (Thomas, 1913) \\
\hline $\begin{array}{l}\text { Family Vespertilionidae (Evening bats) } \\
\text { [23 Genera, } 63 \text { Species] }\end{array}$ \\
\hline 64. Myotis blythii (Tomes, 1857) \\
\hline 65. Myotis sicarius Thomas, 1915 \\
\hline 66. Myotis formosus (Hodgson, 1835) \\
\hline 67. Myotis nipalensis (Dobson, 1871) \\
\hline 68. Myotis muricola (Gray, 1846) \\
\hline 69. Myotis siligorensis (Horsfield, 1855) \\
\hline 70. Myotis montivagus (Dobson, 1874) \\
\hline 71. Myotis annectans (Dobson, 1871) \\
\hline 72. Myotis longipes (Dobson, 1873) \\
\hline 73. Myotis csorbai Topal, 1997 \\
\hline 74. Myotis laniger (Peters, 1871) \\
\hline 75. Myotis horsfieldii (Temminck, 1840) \\
\hline
\end{tabular}




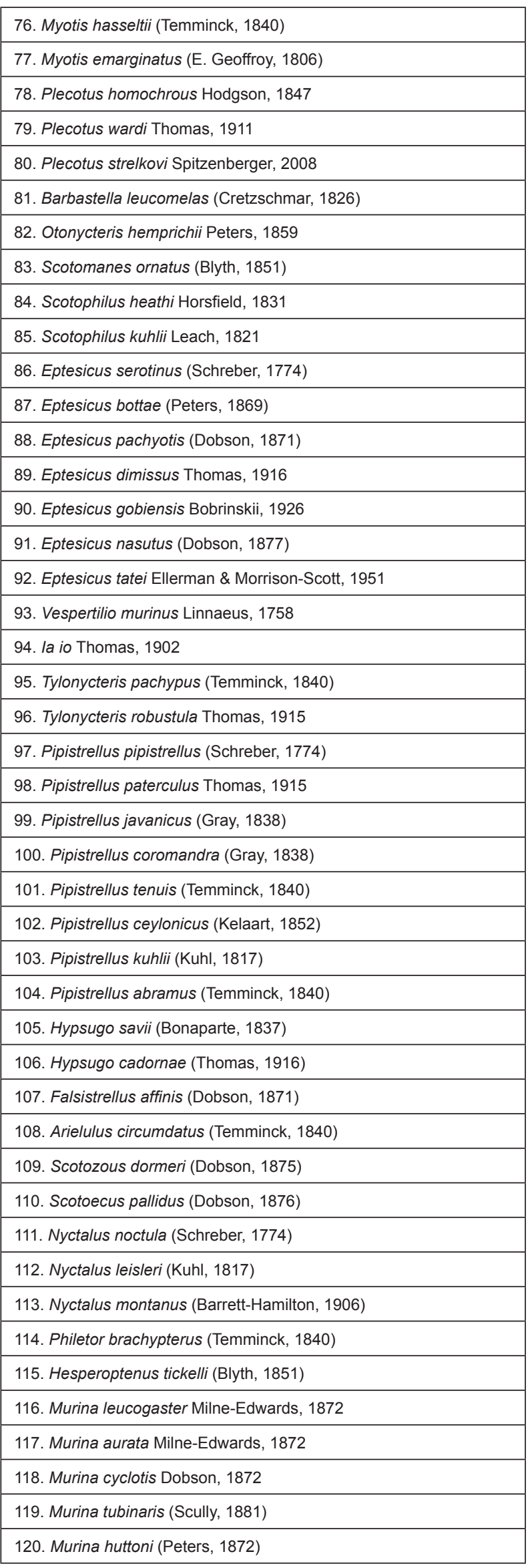

\begin{tabular}{|l|}
\hline 121. Harpiola grisea Peters, 1872 \\
\hline 122. Harpiocephalus harpia (Temminck, 1840) \\
\hline 123. Kerivoula picta (Pallas, 1767) \\
\hline 124. Kerivoula hardwickii (Horsfield, 1824) \\
\hline 125. Kerivoula lenis Thomas, 1916 \\
\hline $\begin{array}{l}\text { Family Miniopteridae (Long-fingered Bats) } \\
\text { [1 Genus, 3 Species] }\end{array}$ \\
\hline 126. Miniopterus schreibersii (Kuhl, 1817) \\
\hline 127. Miniopterus pusillus Dobson, 1876 \\
\hline 128. Miniopterus magnater Sanborn, 1931 \\
\hline
\end{tabular}


1A. Eyes conspicuous ( $>4 \mathrm{~mm}$ in diameter); ear pinna simple, tragus and anti tragus absent; noseleaf absent; second digit of the wing with well-developed phalanges, with claw (with one exception); tail absent, if present small (shorter than $1 / 4$ of tibia); interfemoral membrane reduced or virtually absent; head dog-like in profile

Family Pteropodidae Key 1

1B. Eyes medium to small ( $<3 \mathrm{~mm}$ in diameter); ear pinna with distinctive tragus or/and antitragus; second digit of the wing with reduced phalanges and no claw; tail present (lacking in one family), long (longer than $1 / 2$ of tibia); interfemoral membrane moderate to wide; head not dog-like in profile

Go to 2

2A. Muzzle with a simple or complex noseleaf, with or without supplementary leaflets and other processes; tragus present or absent

2B. Noseleaf usually absent; may or may not have dermal ridge between the nostrils; tragus present

3A. Noseleaf simple, with an erect leaf behind nostrils and a heart-shaped leaf surrounding nostrils; tragus bifid; antitragal lobe not developed; ear pinnae large (nearly $2 / 3^{\text {rd }}$ of the forearm length), fused at bases; tail absent

Family Megadermatidae Key 2

3B. Noseleaf complex, consisting of a horseshoe; tragus absent; antitragal lobe conspicuous; tail enclosed within the interfemoral membrane

4A. Muzzle with small dermal ridge; second and third digits of each wing with two distinct bony phalanges; tail thin with greatest part projecting free from the narrow interfemoral membrane

Family Rhinopomatidae Key 3

4B. Muzzle without a dermal ridge; ears may or may not be joined over the forehead; interfemoral membrane well-developed; tail may or may not be free

5A. Noseleaf triangular with sella between the nostrils; lancet pointed and raising to near or above the forehead; anterior noseleaf horseshoe shaped; antitragus distinct; toes with three joints each

Family Rhinolophidae Key 4

5B. Noseleaf squarish without sella or lancet; anterior noseleaf lobate or horseshoe shaped; posterior leaf simple or complex; supplementary leaflets may or may not be present; antitragus notch-like; toes with two joints each

Family Hipposideridae Key 5

6A. Tail completely enclosed within the wide interfemoral membrane or the last one or two vertebrae are free 
6B. At least a part of the tail free from the interfemoral membrane

7A. Tail completely enclosed within the wide interfemoral membrane or the last one or two vertebrae are free; second phalanx of third finger only sligthly longer than first

Family Vespertilionidae Key 6

7B. Tail completely enclosed within the wide interfemoral membrane; second phalanx of third finger much longer than first, the lengthened distal part folds upon the wing at rest

Family Miniopteridae Key 7

8A. Tail emerging on the upper surface from the mid-point of the interfemoral membrane

Family Emballonuridae Key 8

8B. Tail emerging out from the outer edge of the interfemoral membrane, wrinkle-lipped

Family Molossidae Key 9

\section{Keys to the Genera and Species of Bats of South Asia}

\section{Key 1, Family Pteropodidae (13 species)}

1A. Second digit of the wing lacks a claw (claw present only on thumb); tongue sharply pointed and protrusible; tail relatively long, about equal to hind foot length; a pair of large anal glands distinct; Four upper and four lower incisors; FA: 66.0-78.0 mm; CBL: 31.7$36.3 \mathrm{~mm}$; $\mathrm{CM}^{2}$ : 11.9-13.4 mm

Eonycteris spelaea

1B. Claws present on both thumb and second digit; tail usually shorter than hind foot or obscure

2A. Large body size; in adults, forearm length more than $110 \mathrm{~mm}$

2B. Small to medium body size; in adults, forearm length less than $100 \mathrm{~mm}$

3A. Forearm less than $150 \mathrm{~mm}$; ears moderate in length, bluntly rounded

3B. Forearm usually longer than $150 \mathrm{~mm}$; ears long (E: $28.0-57.0 \mathrm{~mm})$, more or less pointed

4A. Tail extremely short ( $5 \mathrm{~mm}$ or less) or absent

4B. Tail longer than $10 \mathrm{~mm}$ 
5A. Pelage on the back pale russet brown with gray and black hairs; ear length 25.0-28.0 $\mathrm{mm}$, short and broad, tips rounded; FA: 135.0-145.0 mm; CBL: 59.0-64.1 mm; CM²: 22.8$25.7 \mathrm{~mm}$

Pteropus hypomelanus

5B. Pelage on the back blackish-brown with white hairs; ear length about $22.0 \mathrm{~mm}$, moderate and broad, tips rounded; FA: 110.0-116.0 mm; CBL: 48.6mm; CM²: 19.0-19.2 $\mathrm{mm}$

Pteropus faunulus

$6 \mathrm{~A}$. Pelage on the back blackish-brown with a few paler hairs and on ventral side pale tan to deep orange red or chestnut brown; FA: 145-183 mm; CBL: 61.5-74.9 mm; CM²: 24.0-29.0 $\mathrm{mm}$

Pteropus giganteus

6B. Pelage on the back blackish brown with a few paler hairs and on ventral side dark brown or blackish-brown; FA: 148.0-163.0 mm; CBL: 63.3-70.7 mm; CM²: 24.6-27.9 mm

Pteropus melanotos

7A. Muzzle narrow and elongate, slightly curved downwards; tongue very long and slender with papillae on distal part; tail absent or rudimentary $(3.5-5.5 \mathrm{~mm})$; wing membrane attached to dorsal side of foot; FA: 44.0-52.0 mm; CBL: 26.6-27.1 mm; CM²: 8.6-8.8 mm

Macroglossus sobrinus

7B. Muzzle not narrow and elongate, not curved downwards; tongue moderately long, lacks papillae on distal part; tail totally absent; wing membrane attached to the outer side of the foot or to outmost digit

8A. Forearm less than $75 \mathrm{~mm}$; muzzle short and relatively broad; ears with conspicuous white margins

8B. Forearm longer than $75 \mathrm{~mm}$; muzzle moderate in length and breadth; ears without any white margins

9A. Forearm greater than $65 \mathrm{~mm}$; one pair each of upper and lower incisors present; FA: 66.0-69.0 mm; CBL: 31.4-33.0 mm; $\mathrm{CM}^{1}$ : 11.3-11.8 mm

Latidens salimalii

9B. Forearm lesser than $65 \mathrm{~mm}$; two pairs of upper incisors, one or two pairs of lower incisors present

10A. Ears large (E: 17.5-24.0 mm) with well-developed pale anterior and posterior border; metacarpals and phalanges pale; FA: 64.0-79.0 mm; CBL: 28.4-33.3 mm; $\mathrm{CM}^{1}$ : 10.2-12.2 $\mathrm{mm}$

Cynopterus sphinx

10B. Ears small (E: $14.5-18.0 \mathrm{~mm}$ ) with poorly developed or no pale anterior and posterior border; metacarpals and phalanges dark; FA: 57.3-63.3 mm; CBL: 26.0-28.8 mm; CM'1: 8.9-10.7 mm

Cynopterus brachyotis 
11A. FA: 83.0-90.0 mm; T: 14.0-20.0 mm; CBL: 36.9 -40.4 mm; CM²: 14.9-16.6 mm

Rousettus aegyptiacus

11B. FA: 75.0-86.0 mm; T: 8.0-21.0 mm; CBL: 33.5-37.7 mm; $\mathrm{CM}^{2}:$ 13.5-15.2 mm

Rousettus leschenaultii

12A. Muzzle moderate; distance between eye and nostril equal to that between eye and ear; ears with thin white margins; rudimentary interfemoral membrane entirely concealed with dense and long fur on hind limbs; two pairs of lower incisors; FA: 52.0-61.0 mm; CBL averages $26.2 \mathrm{~mm} ; \mathrm{CM}^{1}$ : 8.0-8.1 $\mathrm{mm}$

Sphaerias blanfordi

12B. Muzzle very short and broad; distance between eye and nostril less than that between eye and ear (auditory meatus); ears without any white margins; interfemoral membrane visible, not entirely concealed by fur; one pair of lower incisors; FA: 52.0-63.0 mm; CBL: 25.6-26.7 mm; $\mathrm{CM}^{1}$ : 8.4-8.6 mm

Megaerops niphanae

\section{Key 2 Family Megadermatidae (2 species)}

1A. Vertical noseleaf tall (c'10mm), straight sided with longitudinal ridge and a simple rounded horizontal base; inner margins of the ears fused at about $30 \%$ of its height; FA: 56.0-71.5 mm; CCL: 24.5-27.8 mm; $\mathrm{CM}^{3}$ : 10.6-12.1 mm

Megaderma lyra

1B. Vertical noseleaf short (c' $6.5 \mathrm{~mm}$ ); convex sided with longitudinal ridge and a distinctly heart-shaped base; inner margins of the ears fused at about $15 \%$ or less of its height; FA: 54.0-62.0 mm; CCL: 21.9-23.6 mm; CM³: 9.3-10.5 mm

Megaderma spasma

\section{Key 3, Family Rhinopomatidae (3 species)}

1A. Tail (50.0-77.0 mm) shorter than FA; FA: 59.5-74.6 mm; CCL: 17.2-22.7 mm; $\mathrm{CM}^{3}:$ : 7.0$8.0 \mathrm{~mm}$

Rhinopoma microphyllum

1B. Tail (49.0-78.0 mm) longer than FA; FA: 46.0-64.0 mm

2A. Dermal ridge on the muzzle well-developed; FA: 52.9-64.0 mm; CCL: 15.5-17.5 mm; $\mathrm{CM}^{3}:$ 6.0-6.8 $\mathrm{mm}$

Rhinopoma hardwickii

2B. Dermal ridge on the muzzle poorly developed; FA: 46.0-53.2 mm; CCL: 14.7-15.1 mm; $\mathrm{CM}^{3}:$ 5.3-5.9 mm

Rhinopoma muscatellum 


\section{Key 4, Family Rhinolophidae (20 species)}

1A. Sella with lateral projecting lappets at its base

1B. Sella lacking lateral basal lappets

2A. Noesleaf and ears brownish; inferior surface of the sella broad (c'4.3mm)

2B. Noseleaf and ears yellowish; inferior surface of the sella relatively narrow (c' $1.4 \mathrm{~mm}$ at the apex); FA: 50.0-53.3 mm; CCL: 19.5-21.5 mm; $\mathrm{CM}^{3}:$ 8.4-8.9 mm

Rhinolophus trifoliatus

3A. Connecting process pointed

3B. Connecting process rounded, not pointed

4A. Large in size (FA $>70.0 \mathrm{~mm})$; inferior surface of the sella parallel-sided and broad (c'4.3mm); FA: 70.0 -80.5 mm; CCL: 27.5-28.7 mm; CM³: 11.8-12.6 mm

Rhinolophus luctus

4B. Small in size (FA $<65.0 \mathrm{~mm})$; inferior surface of the sella parallel-sided and moderately broad (c'2.4mm); FA: 54.9-64.3 mm; CCL: 22.2-24.4 mm; CM³: 9.6-10.4 mm

Rhinolophus beddomei

5A. Anterior median swellings moderately low, protruding anteriorly

5B. Anterior median swellings higher, directing upwards

6A. Connecting process low, rounded, its tip pointed more or less downwards; superior connecting process broadly rounded and low; FA: 35.9-40.0 mm; CCL: 13.0-14.0 mm; $\mathrm{CM}^{3}$ : 4.6-5.5 mm

Rhinolophus hipposideros

6B. Connecting process well-developed, rounded, its tip pointed more or less forwards

7A. Sella parallel-sided; dorsal pelage light brown, well marked dark brownish patches under each eye; ventral pelage light grayish-brown or even purely white; FA: 47.0-53.0 mm; GTL: 18.8-20.4 mm; $\mathrm{CM}^{3}$ : 6.2-7.2 mm

Rhinolophus mehelyi

7B. Sella wedge-shaped; dorsal pelage light brown to yellowish-brown, ventral pelage grayish, white or creamy; FA: 43.0-50.0 mm; CCL: 16.0-17.0 mm; $\mathrm{CM}^{3}$ : 6.0-7.6 mm

Rhinolophus blasii

8A. Superior process more horn like 
8B. Superior process not horn like

9A. Connecting process forming a continuous arch or obsolete; lower lip with one mental groove, internarial not expanded

9B. Connecting process not forming a continuous arch

10A. Base of the sella broadly rounded; FA: $34.9-37.8 \mathrm{~mm}$; CCL: $13.0-14.0 \mathrm{~mm}$; $\mathrm{CM}^{3}: 5.4-$ $6.0 \mathrm{~mm}$

Rhinolophus pusillus

10B. Base of the sella not broadly rounded

11A. Small skull (GTL usually $<17.0 \mathrm{~mm}$ ); small upper canine, feeble saggital crest; FA: 37.0-41.8 mm; GTL: 15.7-17.3 mm; $\mathrm{CM}^{3}:$ 5.6-6.8 mm

Rhinolophus lepidus

11B. Heavy built skull (GTL usually $>17.0 \mathrm{~mm}$ ); very long upper canine, strong saggital crest; FA: 39.0-42.0 mm; GTL: 17.2-17.9 mm; CM³: 6.5-7.2 mm

Rhinolophus shortridgei

12A. Inferior surface of the sella not rounded and the base expanded

12B. Inferior surface of the sella rounded and the base narrow; FA: $\sim 57.1 \mathrm{~mm}$; $\mathrm{T}$ : $\sim 30.0 \mathrm{~mm}$

Rhinolophus mitratus

13A. Sella long and wide; palatal bridge more than $1 / 3^{\text {rd }}$ length of maxillary toothrow $\mathrm{CM}^{3}$; superior connecting process broadly rounded; inferior extremity short and emarginated; lancet short with pointed tip; FA: 39.0-46.0 mm; CCL: 15.2-16.6 mm; CM³: 6.2-6.7 mm

Rhinolophus macrotis

13B. Sella shorter and narrower; palatal bridge less than $1 / 3^{\text {rd }}$ length of maxillary toothrow $\mathrm{CM}^{3}$

14A. Large in size; horn like superior connecting process slightly curved downwards; FA: 37.5-40.7 mm; CCL: 14.2-15.8 mm; $\mathrm{CM}^{3}:$ 6.0-7.0 mm

Rhinolophus cognatus

14B. Small in size; horn like superior connecting process not curved downwards; FA: 33.435.9 mm; CCL: 11.9-12.9 mm; CM³ : 5.1-5.5 mm

Rhinolophus subbadius

15A. Small; FA: 50.8-54.8 mm; CCL: 20.2-21.6 mm; CM³: 9.2-9.9 mm

Rhinolophus pearsonii

15B. Large; FA: 54.2-59.5 mm; CCL: 22.3-22.9 mm; CM³: 9.5-10.6 mm

Rhinolophus yunanensis 
16A. Connecting process high and bluntly rounded, anterior upper premolar when present always minute and fully extruded from the tooth row

16B. Connecting process lower and rounded, anterior premolar larger and usually in row or only slightly extruded, very rarely totally external

17A. Large (FA >53.0mm); FA: 54.8-62.1 mm; GTL: 20.8-24.9 mm; $\mathrm{CM}^{3}:$ 8.5-9.6 mm Rhinolophus ferrumequinum

17B. Small (FA <53.0mm); FA: 47.5-53.0 mm; GTL: 19.0-22.2 mm; $\mathrm{CM}^{3}:$ 6.7-7.2 mm Rhinolophus bocharicus

18A. Lancet triangular, lateral margins more or less straight; FA: 50.0-55.0 mm; CCL: 18.7$20.5 \mathrm{~mm} ; \mathrm{CM}^{3}:$ 8.5-9.5 mm

Rhinolophus affinis

18B. Lancet abruptly narrowed at central, its lateral margins strongly concave

19A. Second phalanx of third metacarpal 52.8-66.0\% of its length; FA: $44.4-52.3 \mathrm{~mm}$; CCL: 17.5-21.0 mm; $\mathrm{CM}^{3}: 7.9-9.2 \mathrm{~mm}$

Rhinolophus rouxii

19B. Second phalanx of third metacarpal $65.0-75.3 \%$ of its length; FA: $45.7-49.6 \mathrm{~mm}$; CCL: 17.4-18.4 mm; $\mathrm{CM}^{3}: 7.6-8.2 \mathrm{~mm}$

Rhinolophus sinicus

\section{Key 5, Family Hipposideridae (15 species)}

1A. Tail long and enclosed within interfemoral membrane, except for the extreme tip; supplementary lappets absent; noseleaf with or without supplementary leaflets

1B. Tail rudimentary $(<2.0 \mathrm{~mm})$; interfemoral membrane much reduced and narrow; anterior noseleaf, deeply emarginated anteriorly, extends beyond muzzle; with forwardly projecting two supplementary lappets; FA: 37.8-42.0 mm; CCL: 14.3-14.8 mm; CM ${ }^{3}$ : 5.8$6.0 \mathrm{~mm}$

Coelops frithi

2A. Posterior leaf of the noseleaf with three vertical processes

2B. Posterior leaf of the noseleaf without three vertical processes

3A. Narial lappets well-developed; ears small funnel shaped; noseleaf with a single pair of supplementary leaflets; a fourth vertical process projecting downwards also present; FA: 48.3-54.0 mm; CBL: 16.9-18.9 mm; $\mathrm{CM}^{3}:$ 6.1-7.1 mm 
3B. Narial lappets less developed; ears broad with pointed tips; noseleaf with two pairs of supplementary leaflets; the central vertical process taller and pointed than others;

FA: 50.1-52.3 mm; CCL: 15.7-17.0 mm; $\mathrm{CM}^{3}:$ 6.5-7.2 mm

Asellia tridens

4A. Noseleaf without supplementary leaflets

4B. Noseleaf with supplementary leaflets

5A. Ears moderate, averages less than 18.0mm (E: 13.0-20.0 mm)

5B. Ears large, averages more than 20.0mm (E: 18.5-26.0 mm)

6A. Two or less than two supplementary leaflets

6B. Three or four supplementary leaflets

7A. Jugal bone of each zygoma with dorsal process; fourth metacarpal exceeds fifth; FA: 34.9-42.3 mm; CCL: 13.2-15.0 mm; $\mathrm{CM}^{3}:$ 5.1-5.9 mm

Hipposideros ater

7B. Jugal bone of each zygoma lacking the dorsal process

8A. Zygomata exceeds braincase in width; third metacarpal shorter than fourth; FA: 38.4$44.0 \mathrm{~mm}$; CCL: 15.0-16.4 mm; CM³: 6.0-6.9 mm

Hipposideros fulvus

8B. Zygomata equal to braincase in width; third metacarpal shorter than fifth; FA: 38.143.2 mm; CCL: 14.6-2-16.0 mm; $\mathrm{CM}^{3}$ : 5.5-6.2 mm

Hipposideros pomona

9A. One supplementary leaflet; fifth metacarpal shorter than the third; FA: 37.1-40.0 mm; CCL: 14.2-14.8 mm; $\mathrm{CM}^{3}:$ 5.3-5.7 mm

Hipposideros hypophyllus

9B. Two supplementary leaflets; fifth metacarpal significantly shorter than the third; FA: 45.0-51.3 mm; CCL: 14.6-15.8 mm; CM3: 5.3-6.2 mm

Hipposideros galeritus

10A. Three supplementary leaflets, third sometimes reduced or absent

10B. Four supplementary leaflets, fourth sometimes reduced or absent

11A. Small; tail projects up to $1.0 \mathrm{~mm}$ beyond the interfemoral membrane; FA: $33.0-36.3$ $\mathrm{mm}$; CCL: 12.7 -13.7 mm; CM³: 4.9-5.3 mm 
11B. Large; tail projects up to $2.5-4.0 \mathrm{~mm}$ beyond the interfemoral membrane; FA: 36.0 $37.5 \mathrm{~mm}$; CBL: 13.0 -13.9 mm; $\mathrm{CM}^{3}$ : 5.0-6.0 mm

Hipposideros durgadasi

12A. Small in size; outer supplementary leaflet distinctly small; ears markedly small

(E: 12.5-9.0 mm); FA: 45.6-54.0 mm; CCL: 15.9-17.5 mm; $\mathrm{CM}^{3}:$ 6.6-7.5 mm

Hipposideros speoris

12B. Large in size; outer supplementary leaflet normal; ears relatively large ( $\mathrm{E}:$ 23.0-26.0 $\mathrm{mm}$ ); FA: 61.2-64.8 mm; CCL: 20.8-21.4 mm; CM³: 8.9-9.4 mm

Hipposideros larvatus

13A. Small in size, forearm less than 65.0; outer leaflet distinctly small or even absent; fleshy outgrowths behind posterior leaf or even protuberances before eyes lacking;

FA: 58.8-64.2 mm; CCL: 22.6-22.9 mm; CM³: 9.7-10.0 mm

Hipposideros diadema

13B. Large in size, forearm in the range of 75.0-99.0 mm; fleshy outgrowths present behind posterior leaf, at least in the form of small protuberances before the eyes

14A. Second upper incisor greatly enlarged; dorsal pelage fawn, yellow, brown or red; ears short (E: 19.5 -30.0 mm); outer leaflet slightly reduced; FA: 75.0-99.0 mm; CCL: 24.8-31.5 $\mathrm{mm} ; \mathrm{CM}^{3}:$ 11.6-14.5 mm

Hipposideros lankadiva

14B. Second upper incisor not greatly enlarged; dorsal pelage dark brown; ears large (E: 26.0-34.0 mm); outer leaflet distinctly small; FA: 85.4-95.0 mm; CCL: 25.6-29.2 mm; $\mathrm{CM}^{3}: 11.3-12.5 \mathrm{~mm}$

Hipposideros armiger

\section{Key 6, For subfamilies of the family Vespertilionidae (63 species)}

1A. Nostrils elongated and tubular

Murininae, Key 6A

1B. Nostrils not elongated

2A. Ears funnel-shaped

Kerivoulinae, Key 6B

2B. Ears not funnel-shaped

3A. Tragus long, slender, bluntly pointed more or less straight, its length along the anterior margin at least three times its greatest width; usually three pairs of upper and lower premolars

Myotinae, Key 6C

3B. Tragus shorter, wider, generally rounded at tip, usually curved forwards, its length along the anterior margin usually less than three times its greatest width; less than three pairs of upper and lower premolars

Vespertilioninae, Key 6D 


\section{Key 6A, Subfamily Murininae (8 species)}

1A. Forearm less than $44.0 \mathrm{~mm}$, last upper molar normal

1B. Forearm more than $44.0 \mathrm{~mm}$, last upper molar reduced, often deciduous; FA: 44.1-50.1 $\mathrm{mm}$; CCL: 19.0-19.5 mm; $\mathrm{CM}^{3}:$ 6.5-6.9 mm

\section{Harpiocephalus harpia}

2A. Upper incisors $\left(\mathrm{I}^{2}\right.$ and $\left.\mathrm{I}^{3}\right)$ are approximately two-third that of the $\mathrm{C}^{1}$ in height; wings attached to the base of the first toe; interfemoral membrane densely covered with rather long hairs above and naked below; FA: 32.8mm; CCL: 12.1mm; $\mathrm{CM}^{3}: \sim 4.9 \mathrm{~mm}$

\section{Harpiola grisea}

2B. Upper incisors $\left(\mathrm{I}^{2}\right.$ and $\left.\mathrm{I}^{3}\right)$ are almost one-half that of the $\mathrm{C}^{1}$ in height

3A. Wings attached to the base of the first toe; ears with faint to distinct emargination on the posterior border

3B. Wings attached to the base of the claw of the first toe; ears without emargination on the posterior border

4A. Emargination on the posterior border of the ear indistinct; interfemoral membrane moderately covered with pale gray or ferruginous hairs above and naked below; FA: 30.1 34.1 mm; CCL: 13.4-14.2 mm; $\mathrm{CM}^{3}$ : 5.0-5.4 mm

\section{Murina tubinaris}

4B. Emargination on the posterior border of the ear distinct and conspicuous; Interfemoral membrane moderately covered with long thick reddish hair above and naked below; FA: $\sim 40.9 \mathrm{~mm}$; CCL: 16.3mm; $\mathrm{CM}^{3}: \sim 6.1 \mathrm{~mm}$

Murina leucogaster

5A. Interfemoral membrane naked below

5B. Interfemoral membrane moderately covered with golden hairs above and gray hairs below; FA: 27.7-29.6 mm; CCL: 12.3mm; $\mathrm{CM}^{3}: \sim 4.5 \mathrm{~mm}$

Murina aurata

6A. FA: 32.8-35.4 mm; CCL: 14.9-15.5 mm; $\mathrm{CM}^{3}:$ 5.8-6.1 mm; Skull relatively long with average CCL being $15.2 \mathrm{~mm}$

Murina huttoni

6B. FA: 29.7-34.5 mm; CCL: 123.9-15.0 mm; $\mathrm{CM}^{3}$ : 5.2-5.7 mm; Skull relatively small with average CCL being $14.4 \mathrm{~mm}$

Murina cyclotis 


\section{Key 6B, Subfamily Kerivoulinae (3 species)}

1A. Wing membranes parti-coloured orange and black; interfemoral membrane orange to scarlet, hairy above; FA: 31.5-37.9; CCL: 12.2-13.3 mm; CM³ : 5.5-5.8 mm

Kerivoula picta

1B. Wing membranes uniformly brown

2A. Interfemoral membrane sparsely haired above near body parts and posterior border; FA: 31.7-36.0 mm; CCL: 12.4-13.0 mm; CM³: 5.5-5.8 mm

Kerivoula hardwickii

2B. Interfemoral membrane lacks hair, sometimes with whitish veins; FA: 37.2-41.0 mm; CCL: 14.5-15.1 mm; CM³: 6.6-6.8 mm

Kerivoula lenis

\section{Key 6C, Subfamily Myotinae (14 species)}

1A. Wings, forearm and interfemoral membrane conspicuously parti-coloured black, red, orange and yellow; FA: 44.5-49.1 mm; CCL: 16.3-16.6 mm; $\mathrm{CM}^{3}:$ 6.8-7.2 mm

Myotis formosus

1B. Wings, forearm and interfemoral membrane not parti-coloured

2A. Outer margin of the ear with conspicuous emarginations; FA: 36.0-41.0 mm

Myotis emarginatus

2B. Outer margin of ear lacking any conspicuous emarginations

3A. Foot including the claws less than half of the tibia

3B. Foot including the claws half to three fourth of the tibia

4A. Small (FA $<37.0 \mathrm{~mm}$ ); Forearm in the range of $30.0-37.0 \mathrm{~mm}$

4B. Large (FA $>44.0 \mathrm{~mm})$; Forearm in the range of $44.7-54.6 \mathrm{~mm}$

5A. Wings attached to the side of the foot immediately below the ankle

5B. Wings attached to the foot at the ankle or little above 
6A. Canines and molars very weak; FA: 30.0-31.5 mm; CCL: 11.2mm; $\mathrm{CM}^{3}:$ 4.7-4.8 $\mathrm{mm}$

Myotis siligorensis

6B. Canines and molars well-developed

7A. Ear relatively large (about $32 \%$ of the HB); FA: 48.1-54.6 mm; CCL: 16.9-17.7 mm; $\mathrm{CM}^{3}:$ 7.1-7.5 mm

\section{Myotis sicarius}

7B. Ears not large $(<32 \%$ of the $\mathrm{HB})$

8A. Dorsal pelage sooty gray brown; FA: 34.8mm; CBL: 10.6-11.9 mm; $\mathrm{CM}^{3}:$ 4.8-5.0 $\mathrm{mm}$

Myotis laniger

8B. Dorsal pelage black; FA: 36.5-41.5 mm; CCL: 13.4-14.3 mm; CM³: 5.5-5.9 mm

Myotis horsfieldii

9A. Tragus short and narrow; dorsal pelage dark brown; FA: 37.2-40.3 mm; CCL: 14.0$14.6 \mathrm{~mm}$; $\mathrm{CM}^{3}$ : 5.8-6.0 mm

Myotis hasseltii

9B. Tragus long and narrow; dorsal pelage brown

10A. Braincase domed or bulbous; ventral pelage pale gray to cream; FA: $34.5-36.8 \mathrm{~mm}$; CCL: 11.6-12.4 mm; $\mathrm{CM}^{3}:$ 4.7-5.3 mm

Myotis nipalensis

10B. Braincase flatter; ventral pelage brownish; FA: 31.2-37.0 mm; CCL: 11.5-12.3 mm; $\mathrm{CM}^{3}:$ 4.8-5.3 $\mathrm{mm}$

Myotis muricola

11A. Ears small, about 25\% of HB; FA: 44.7-46.8 mm; CCL: 15.1-15.6 mm; CM³: 6.5-6.8 $\mathrm{mm}$

Myotis montivagus

11B. Ears large, about $30 \%$ of the HB; FA: 45.3-46.5 mm; CCL: $14.9-15.5 \mathrm{~mm}$; $\mathrm{CM}^{3}:$ : 6.5-6.7 $\mathrm{mm}$

Myotis annectans

12A. Large in size (FA $>55.0 \mathrm{~mm}$ ); interfemoral membrane pale brown and hairless throughout; FA: 55.5-58.3 mm; CCL: 18.1-18.9 mm; CM³: 8.2-8.5 mm

Myotis blythii

12B. Small in size $(F A<41.0 \mathrm{~mm})$

13A. FA: 36.5-39.0 mm; TIB: 14.4-17.80 mm; CBL: 12.77-13.76 mm; ZB: $8.4 \mathrm{~mm}$; $\mathrm{CM}^{3}: 5.1-5.3 \mathrm{~mm}$

Myotis longipes

13B. FA: 34.80-37.50 mm; TIB: 14.84-15.80 mm; CBL: 12.11-12.71 mm; ZB: 7.59-8.19 mm; $\mathrm{CM}^{3}: 4.72-5.19 \mathrm{~mm}$

Myotis csorbai 


\section{Key 6D, For tribes of the subfamily Vespertilioninae (38 species)}

1A. Nostrils margined by grooves on the upper surface of the muzzle; ears long, joined, or may not be joined, across the forehead

Plecotini, Key 6D i

1B. Nostrils simple, opening by crescentic or circular apertures at the extremity of the muzzle; ears generally moderate, forehead not grooved

2A. Total teeth 30 ; dental formula $1113 / 3123$

\section{Nycticeiini, Key 6D ii}

2B. Total teeth 32-34; dental formula 211(2)3/3123

3A. First upper premolar usually absent, except in genus Arielulus where it is present; dental formula $2113 / 3123$ in former, $2123 / 3123$ in later

\section{Eptesicini, Key 6D iii}

3B. First upper premolar usually present; dental formula 2123/3123

4A. Medium to large bats (FA between 25.0-57.8 mm); pipistrelles, with pararhinal glands (highly variable genus Pipistrellus) or pipistrelle-like with relatively less depressed skull and absence or variable presence of $\mathrm{I}^{2}$ (genus Scotozous) or with narrow wings, high and broad rostra (genus Nyctalus)

Pipistrellini, Key 6D iv

4B. Medium to very large bats (FA between 26.1- $77.3 \mathrm{~mm}$ ); pipistrelle-like with variable characters, like enlarged pads on feet and base of thumbs (genus Tylonycteris), rounded braincase (genus Philetor), large size with forearm usually greater than $70.0 \mathrm{~mm}$ (genus la), skull with full rostrum (genus Vespertilio), absence of keeled calcar (genus Hypsugo) or with pararhinal glands (genus Falsistrellus) 


\section{Key 6D i, Tribe Plecotini (5 species)}

1A. Ears long, greater than $30 \mathrm{~mm}$ in length

1B. Ears, joined over forehead by a band of integument, are short, up to $18 \mathrm{~mm}$ in length, barely extending beyond the tip of the muzzle when laid forward, and wide with 5-6 furrows; FA: 38.7-42.1 mm; CCL: 13.4-14.2 mm; CM³: 4.7-5.1 mm

Barbastella leucomelas

2A. Small, foream less than $50 \mathrm{~mm}$; ears longer than $30 \mathrm{~mm}$ with numerous horizontal furrows, joined by an integument over forehead

2B. Large, foream greater than $55 \mathrm{~mm}$; ears longer than $35 \mathrm{~mm}$, but not joined by an integument over forehead; tragus half the height of the pinna; antitragus shallow notchlike; dorsal pelage buffy brown, ventral pelage uniformly pale grey; FA: 64.7-65.6 mm; CCL: 21.7mm; $\mathrm{CM}^{3}: \sim 8.5 \mathrm{~mm}$

Otonycteris hemprichii

3A. Large, forearm greater than $41 \mathrm{~mm}$

4

3B. Small, foream lesser than $41 \mathrm{~mm}$; pelage dense and woolly, uniformly dark brown dorsally and ventrally; ears, wing and tail membranes dark brown; FA: 36.5-40.7 mm; CCL: 13.8-14.2 mm; $\mathrm{CM}^{3}:$ 5.0-5.4 mm

Plecotus homochrous

4A. Pelage dense but not woolly, brownish dorsally and whitish ventrally; ears, wing and tail membranes pale to mid brown; FA: 41.4-44.7 mm; CCL: $14.8-15.5$ mm; CM³: 5.4-5.8 $\mathrm{mm}$

Plecotus wardi

4B. Pelage not very dense dorsally and shaggy ventrally, cold grayish-drab dorsally and yellowish white ventrally; ears, wing and tail membranes semitransparent cold brown; FA: 39.6-44.8 mm; CCL: 14.1-15.6 mm; $\mathrm{CM}^{3}$ : 5.3-6.1 mm

Plecotus strelkovi 


\section{Key 6D ii, Tribe Nycticeiini (4 species)}

1A. Small size (Forearm less than $38.0 \mathrm{~mm}$ ); head flattened with broad and flat muzzle; tragus long and narrow; FA: 34.1-37.3 mm; CCL: 13.8-14.8 mm; $\mathrm{CM}^{3}$ : 5.5-5.9 mm

Scotoecus pallidus

1B. Large size (Forearm more than $44.0 \mathrm{~mm}$ ); head not flattened

2A. Dorsal pelage orange brown with white spots on crown, back and shoulders; ears large and lacking any ridges; FA: 56.1-61.2 mm; CCL: 20.1-20.9 mm; $\mathrm{CM}^{3}:$ : 7.8-8.5 mm

Scotomanes ornatus

2B. Dorsal pelage tawny or chestnut brown, lacks any marking; ears small with numerous transverse ridges

3A. Large (Forearm averaging $60.7 \mathrm{~mm}$ ); ventral pelage with distinctly yellow tinge; FA: 55.4-65.8 mm; CCL: 19.0-21.3 mm; CM³: 7.1-8.4 mm

Scotophilus heathi

3B. Smaller (Forearm averaging 49.0mm); ventral pelage buffy brown; FA: 44.0-56.4 mm; CCL: 16.3- $18.0 \mathrm{~mm}$; $\mathrm{CM}^{3}$ : 6.1-6.8 mm

Scotophilus kuhlii 


\section{Key 6D iii, Tribe Eptesicini (9 species)}

1A. Ears with well-visible white margins; dorsal pelage is dark brown, the tip of longer guard hairs are bright cuprous-red or golden; interfemoral membrane uniformly dark brown; broad tragus has pale margin; FA: 41.8-43.6 mm; CCL: 14.6-15.6 mm; CM³: 6.0$6.5 \mathrm{~mm}$

\section{Arielulus circumdatus}

1B. Ears lacking white or pale magins; dorsal pelage lacks cuprous-red or orange hue

2A. Ears thick and fleshy, yellowish-brown, without ridges; dorsal pelage with distinct yellowish tinge; FA: 50.0-60.4 mm; CCL: 17.2-19.6 mm; CM³: 6.5-6.9 mm

Hesperoptenus tickelli

2B. Ears with conspicuous ridges, dark; dorsal pelage without yellowish tinge

3A. Large in size ( $F A>50.0 \mathrm{~mm}$ ); ears moderately tall averaging $14.0 \mathrm{~mm}$, bears six transverse ridges; FA: 54.2-55.1 mm; CCL: 18.3-19.5 mm; CM³: 7.1-7.8 mm

Eptesicus serotinus

3B. Small in size (FA $<50.0 \mathrm{~mm}$, in the range of $35.4-45.3 \mathrm{~mm})$

4A. Membranes and naked areas pale yellow; FA: 41.0-41.5 mm; CBL: 15.1mm; $\mathrm{CM}^{3}:$ $5.9 \mathrm{~mm}$

Eptesicus gobiensis

4B. Membranes and naked areas shades of brown

5A. Pelage black throughout; FA: 43.4mm; HB: 48.5mm; T: 45.9mm

Eptesicus tatei

5B. Pelage not uniformly black throughout

6A. Ears triangular in shape with rounded tips; tragus short; proximal part of ear thick and fleshy; FA: 38.0-40.3 mm; HB: 55.0-56.0 mm; T: 40.0-41.0 mm; GTL: 21.2mm

Eptesicus pachyotis

6B. Ears not triangular in shape; proximal part of ear normal

7A. Tail nearly as long as the $\mathrm{HB}(>90 \%)$, rostrum short; FA: 35.4-36.9 mm; CCL: 11.7-12.2 $\mathrm{mm} ; \mathrm{CM}^{3}$ : 4.4-4.8 mm

Eptesicus nasutus

7B. Tail not as long as the HB (<85\%), rostrum long

8A. Basioccipital pits prominent; FA: 42mm;

Eptesicus dimissus

8B. Basioccipital pits not very prominent; FA: 42.1mm; CCL: 15.0mm; $\mathrm{CM}^{3}: \sim 5.8 \mathrm{~mm}$

Eptesicus bottae 


\section{Key 6D iv, Tribe Pipistrellini (12 species)}

1A. Ears short (about $28 \%$ of the forearm length) and broad; tragus usually half the height of the pinna, with faintly concave anterior border

1B. Ears relatively short (about $24 \%$ of the forearm length); tragus club-shaped, more than twice wider in distal part than at base

2A. Inner upper incisor $\left(\mathrm{i}^{2}\right)$ large, unicuspidate and in contact with canine or nearly so; outer incisor $\left(i^{3}\right)$ absent, if present, no more than a minute spicule; interfemoral membrae uniformly mid brown, veins sometimes white; FA: 32.7-36.3 mm; CCL: 12.8-13.6 mm; $\mathrm{CM}^{3}$. 5.2-5.6 mm

\section{Scotozous dormeri}

2B. Inner upper incisor $\left(\mathrm{i}^{2}\right)$ usually bicuspidate; outer incisor large similar in crown area to inner and half or more its height

3A. Large (forearm more than 50mm); FA: 50.9-57.8 mm; CCL: 17.1-18.6 mm; CM³: 7.1-7.7 $\mathrm{mm}$

Nyctalus noctula

3B. Small (forearm less than $50 \mathrm{~mm}$ )

4A. Second upper premolar $\left(\mathrm{pm}^{2}\right)$ positioned usually in toothrow; interfemoral membrane haired only above but naked below; FA: 30.0-31.6 mm; CCL: 10.4-11.3 mm; CM³: 4.1-4.4 $\mathrm{mm}$

Pipistrellus pipistrellus

4B. Second upper premolar $\left(\mathrm{pm}^{2}\right)$ intruded

5A. Fur bicoloured; FA: 42.1-45.2 mm; CCL: 14.7-15.2 mm; $\mathrm{CM}^{3}:$ 5.5-5.9 mm

Nyctalus leisleri

5B. Fur uniform brown; FA: 42.9-43.0 mm; CCL: 15.4-16.0 mm; $\mathrm{CM}^{3}$ : 6.5-6.6 mm

Nyctalus montanus

6A. Large (forearm averaging over $35.0 \mathrm{~mm}$ ); pelage on ventral side conspicuously paler than on dorsal side; interfemoral membrane sparsely haired above and below; FA: 33.0$42.0 \mathrm{~mm}$; CCL: $13.1-14.3 \mathrm{~mm}$; $\mathrm{CM}^{3}$ : 5.2-5.9 mm

Pipistrellus ceylonicus

6B. Small (Forearm length averaging less than $35.0 \mathrm{~mm}$ ); pelage on ventral side slightly paler than on dorsal side

7A. Interfemoral membrane pallid and translucent; FA: 33.4-36.0 mm; CCL: 12.0-12.9 $\mathrm{mm} ; \mathrm{CM}^{3}$ : 4.6-5.0 mm

Pipistrellus kuhlii 
7B. Interfemoral membrane not pallid and translucent

8A. Canine lacks secondary posterior cusps; upper molars relatively massive; pelage dark brown; penis over $10 \mathrm{~mm}$ in legth; FA: 29.2-34.0 mm; CCL: 10.6-11.6 mm; $\mathrm{CM}^{3}: 4.1$ $4.8 \mathrm{~mm}$

Pipistrellus paterculus

8B. Canine with posterior secondary cusp

9A. Pelage colouration pale; tragus gradually narrowing along its terminal half, with somewhat pointed apex; penis long, over $8 \mathrm{~mm}$ in length

9B. Pelage colouration usually relatively dark; tragus more or less even together; penis short, less than $8 \mathrm{~mm}$ in length

10A. Large, forearm between 30.0 to $36 \mathrm{~mm}$; interfemoral membrane not haired; penis short, about 8.0-10.0 mm in length; FA: 30.0-36.0 mm; CCL: 11.9 -13.1 mm; CM³: 4.6-5.2 $\mathrm{mm}$

Pipistrellus javanicus

10B. Small, forearm between 31.4 to $34.4 \mathrm{~mm}$; penis long, about $10-13 \mathrm{~mm}$ in length; FA: 31.4-34.4 mm; CCL: 11.4-12.8 mm; $\mathrm{CM}^{3}:$ 4.2-4.9 mm

Pipistrellus abramus

11A. Large, forearm length averaging $30 \mathrm{~mm}$; interfemoral membrane haired near the body both above and below; FA: 25.5-34.3 mm; CCL: 10.6-11.9 mm; CM ${ }^{3}$ : 3.9-4.6 mm

Pipistrellus coromandra

11B. Small, forearm length averaging $28 \mathrm{~mm}$; interfemoral membrane not haired; FA: 25.0 $30.2 \mathrm{~mm}$; CCL: 9.3-10.7 mm; $\mathrm{CM}^{3}$ : 3.5-4.1 mm

Pipistrellus tenuis 


\section{Key 6D v, Tribe Vespertilionini (8 species)}

1A. Soles of the feet expanded in to fleshy pads; head noticeably flattened

1B. Soles of the feet normal; head not flattened

2A. Pelage shades of golden brown; FA: 26.1-29.0 mm; CCL: 10.0-11.3 mm; CM³: 3.4-4.2 $\mathrm{mm}$

Tylonycteris pachypus

2B. Pelage shades of brown; FA: 26.6-28.1 mm; CCL: 11.1-11.7 mm; $\mathrm{CM}^{3}: 3.9-4.4 \mathrm{~mm}$

Tylonycteris robustula

3A. Large bat, forearm greater than 70.0mm; FA: 70.9-77.3 mm; CCL: 25.2-26.2 mm; $\mathrm{CM}^{3}: 10.5-11.0 \mathrm{~mm}$

la io

3B. Small bat, forearm lesser than $70.0 \mathrm{~mm}$

4A. Two upper premolars and two lower premolars

4B. One upper premolar and two lower premolars

5A. Large bat, forearm greater than $38 \mathrm{~mm}$; braincase small; basisphenoid pits absent; FA: 38.4-41.4 mm; CCL: 13.7-14.5 mm; $\mathrm{CM}^{3}$ : 5.5-5.7 mm

Falsistrellus affinis

5B. Small bat, forearm lesser than $38 \mathrm{~mm}$

6A. Tragus fleshy and thickened; FA: $31.7-38.0 \mathrm{~mm}$; CCL: $12.4-13.7 \mathrm{~mm}$; $\mathrm{CM}^{3}:$ 4.5-4.8 $\mathrm{mm}$

Philetor brachypterus

6B. Tragus small and short; FA: 42.0-45.5 mm; CCL: 15.0mm; $\mathrm{CM}^{3}: 4.9-5.5 \mathrm{~mm}$

Vespertilio murinus

7A. Interfemoral membrane sparsely haired near the body; dorsal pelage long, silky and variably chestnut brown; FA: 32.1-38.0 mm; CCL: 12.4-13.3 mm; CM³: 4.6-5.1 mm

Hypsugo savii

7B. Interfemoral membrane mostly naked; dorsal pelage long, silky and dark brown; FA: 32.6-36.5 mm; CCL: 12.6-12.8 mm; CM³: 4.6-4.9 mm

Hypsugo cadornae 


\section{Key 7, Family Miniopteridae (3 species)}

1A. Large with forearm greater than $47 \mathrm{~mm}$ and condylobasal length greater than $15.5 \mathrm{~mm}$; FA: 47.5 -52.8 mm; CBL: 15.7-17.3 mm; $\mathrm{CM}^{3}$ : 6.4-7.3 mm

\section{Miniopterus magnater}

1B. Small with forearm lesser than $50 \mathrm{~mm}$ and condylobasal length lesser than $15.5 \mathrm{~mm}$

2A. Hairs on the interfemoral membrane near body parts; FA: 44.7-49.6 mm; CBL: 14.6$15.5 \mathrm{~mm} ; \mathrm{CM}^{3}:$ 5.8-6.3 mm

Miniopterus schreibersii

2B. Hairs on the interfemoral membrane extend further away from body parts; FA: 39.6$40.2 \mathrm{~mm}$; CBL: $12.7-13.2 \mathrm{~mm}$; $\mathrm{CM}^{3}:$ 5.1-5.3 mm

Miniopterus pusillus

\section{Key 8, Family Emballonuridae (6 species)}

1A. Radio-metacarpal pouch distinct; lower lip scarcely grooved

1B. Radio-metacarpal pouch absent; lower lip deeply grooved; gular sac present in both the sexes (smaller in females); wings attached to ankles; FA: 63.0-68.2 mm; CCL: 21.7$24.6 \mathrm{~mm} ; \mathrm{CM}^{3}:$ 9.8-11.2 $\mathrm{mm}$

Saccolaimus saccolaimus

2A. Radio-metacarpal pouch small; gular pouch less visible; wings attached to tibiae; posterior back and lower abdomen naked; FA: 71.0-80.0 mm; CCL: $21.6-25.6$ mm; CM³: 10.3-11.8 mm

Taphozous nudiventris

2B. Radio-metacarpal pouch well-developed

3A. Gular pouch present; wings attached either to tibiae or ankles

3B. Gular pouch absent; wings attached to tibiae

4A. Gular pouch present in males and absent in females; wings attached to tibiae; FA: 59.2-63.8 mm; CCL: 18.4-19.7 mm; $\mathrm{CM}^{3}:$ 8.2-8.9 mm

Taphozous perforatus

4B. Gular pouch rudimentary in females; wings attached to ankles; posterior back and lower abdomen hairy; FA: 55.6-62.0 mm; CCL: 19.2-21.6 mm; $\mathrm{CM}^{3}$ : 8.7-9.2 mm

Taphozous longimanus 
5A. Large with forearm length greater than $70 \mathrm{~mm}$; wing and interfemoral membrane naked; FA: 71.0- 76.0 mm; CCL: 21.9-23.4 mm; CM³: 9.4-10.5 mm

Taphozous theobaldi

5B. Small with forearm length lesser than $70 \mathrm{~mm}$; dorsal fur extends over wing and interfemoral membranes; males with black beard; FA: 60.0-68.0 mm; CCL: 19.5-21.5 mm; $\mathrm{CM}^{3}:$ 8.6-9.2 mm

Taphozous melanopogon

\section{Key 9, Family Molossidae (4 species)}

1A. Ears not joined by membrane over the forehead

1B. Ears joined by membrane over the forehead

2A. Forearm less than $52.3 \mathrm{~mm}$; two pairs of lower incisors (some aberrant individuals may have three pairs); FA: 46.0-52.3 mm; CCL: 17.1-18.8 mm; $\mathrm{CM}^{3}$ : 7.1-7.8 mm

Tadarida aegyptiaca

2B. Forearm greater than $58.4 \mathrm{~mm}$; three pairs of lower incisors; FA: 58.4-63.9 mm; CCL: 21.6-23.1 mm; $\mathrm{CM}^{3}:$ 8.2-9.3 mm

Tadarida teniotis

3A. Forearm less than 51mm; two pairs of lower incisors; FA: 43.1-50.2 mm; CCL: 15.9$17.1 \mathrm{~mm} ; \mathrm{CM}^{3}:$ 6.4-7.3 mm

Chaerephon plicatus

3B. Forearm greater than $63.0 \mathrm{~mm}$; two (or sometimes three) pairs of small and bifid lower incisors; pelage diagnostic with glossy dark chocolate brown on the back, thin white lines on the flanks and antebrachial membrane; FA: 63.0-67.0 mm; CCL: 21.8-23.2 mm; $\mathrm{CM}^{3}$ : 8.8-9.3 mm

Otomops wroughtoni 


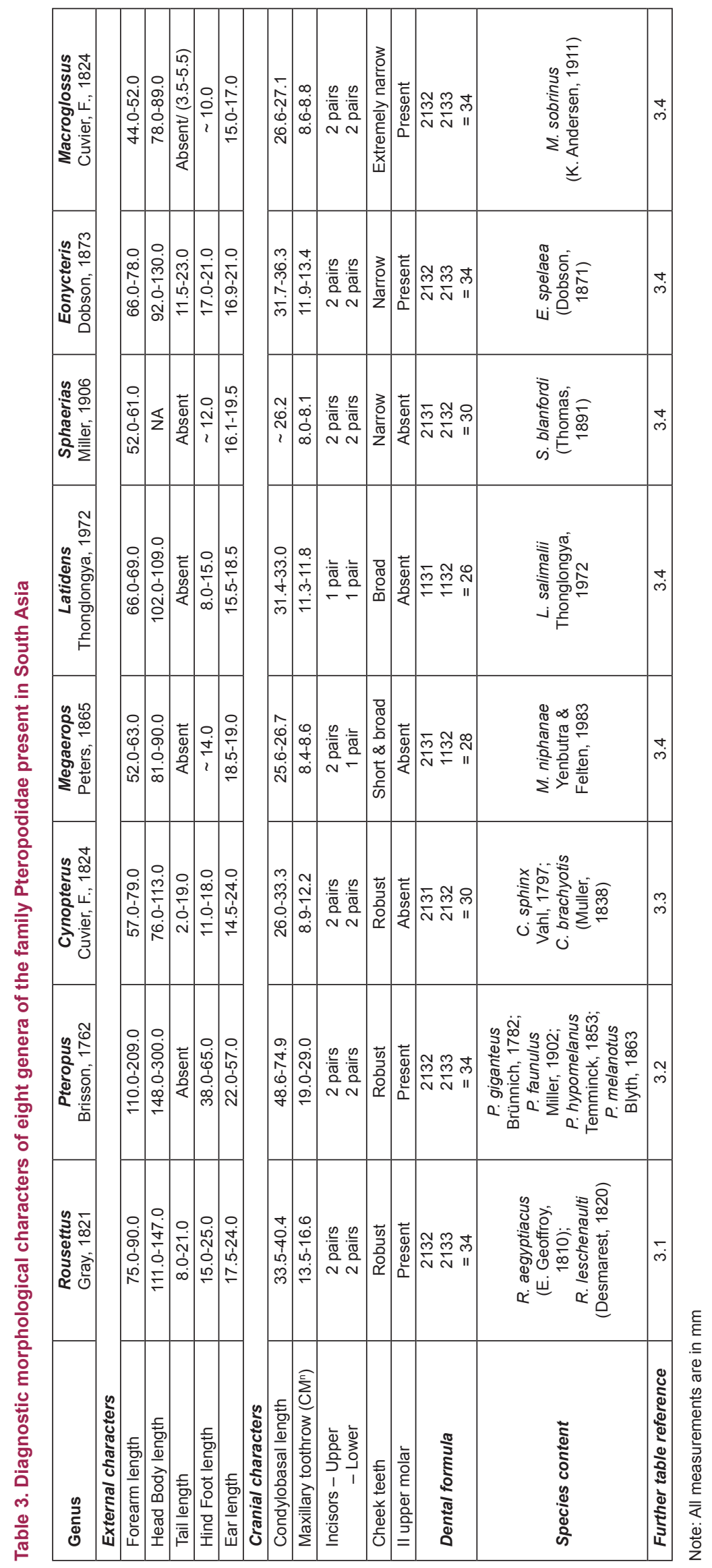


Table 3.1. Diagnostic morphological characters of the two species of the genus Rousettus Gray, 1821 present in South Asia

\begin{tabular}{|l|c|c|}
\hline Species & $\begin{array}{c}\text { Rousettus aegyptiacus } \\
\text { (E. Geoffroy, 1810) }\end{array}$ & $\begin{array}{c}\text { Rousettus leschenaultii } \\
\text { (Desmarest, 1810) }\end{array}$ \\
\hline External characters \\
\hline Forearm length & $83.0-90.0$ & $75.0-86.0$ \\
\hline Head Body length & $113.0-126.0$ & $111.0-147.0$ \\
\hline Tail length & $14.0-20.0$ & $8.0-21.0$ \\
\hline Hind Foot length & $20.0-25.0$ & $15.0-22.0$ \\
\hline Ear length & $18.0-22.0$ & $17.5-24.0$ \\
\hline Thumb (including claw) & $30.0-33.4$ & $24.0-31.3$ \\
\hline II phalanx of 3rd metacarpal & $51.9-56.3$ & $39.6-46.2$ \\
\hline Cranial characters & & $33.5-37.7$ \\
\hline Condylobasal length & $36.9-40.4$ & $13.5-15.2$ \\
\hline Maxillary toothrow $\left(\mathrm{CM}^{2}\right)$ & $14.9-16.6$ & $14.8-16.7$ \\
\hline Mandibular toothrow $\left(\mathrm{CM}_{3}\right)$ & $16.5-18.2$ & $20.2-24.0$ \\
\hline Zygomatic breadth & $23.7-25.2$ & $27.6-31.1$ \\
\hline Mandible length & $30.5-32.7$ & \\
\hline
\end{tabular}

Note: All measurements are in $\mathrm{mm}$

Table 3.2. Diagnostic morphological characters of four species of the genus Pteropus Brisson, 1762 present in South Asia

\begin{tabular}{|c|c|c|c|c|}
\hline Species & $\begin{array}{l}\text { Pteropus giganteus } \\
\text { (Brünnich, 1782) }\end{array}$ & $\begin{array}{l}\text { Pteropus faunulus } \\
\text { Miller, } 1902\end{array}$ & $\begin{array}{c}\text { Pteropus hypomelanus } \\
\text { Temminck, } 1853\end{array}$ & $\begin{array}{l}\text { Pteropus melanotus } \\
\text { Blyth, } 1863\end{array}$ \\
\hline \multicolumn{5}{|l|}{ External characters } \\
\hline Forearm length & $145.0-183.0$ & $110.0-116.0$ & $135.0-145.0$ & $148.0-163.0$ \\
\hline Head Body length & $198.0-300.0$ & $\sim 170.0$ & $199.0-220.0$ & NA \\
\hline Tail length & Absent & Absent & Absent & Absent \\
\hline Hind Foot length & $38.0-58.0$ & $\sim 34.0$ & $\sim 59.2$ & NA \\
\hline Ear length & $\begin{array}{c}\text { 33.0-45.0 } \\
\text { Long \& pointed, triangular } \\
\text { shaped }\end{array}$ & $\begin{array}{l}\sim 22.0 \\
\begin{array}{l}\text { Moderate length, tips } \\
\text { rounded off }\end{array}\end{array}$ & $\begin{array}{l}25.0-28.0 \\
\text { Short \& broad, tips } \\
\text { rounded off }\end{array}$ & $\begin{array}{c}\text { NA } \\
\text { Large \& broad, with } \\
\text { narrow tips }\end{array}$ \\
\hline Rostrum & Long \& robust & Narrow & Narrow & Broad \& robust \\
\hline Pelage on the back & $\begin{array}{l}\text { Blackish-brown with a } \\
\text { few paler hairs }\end{array}$ & $\begin{array}{l}\text { Blackish-brown with } \\
\text { white hairs }\end{array}$ & $\begin{array}{l}\text { Pale russet brown with } \\
\text { gray \& black hairs }\end{array}$ & $\begin{array}{l}\text { Blackish-brown with } \\
\text { a few gray hairs }\end{array}$ \\
\hline Ventral surface & $\begin{array}{l}\text { Pale tan to deep orange } \\
\text { red or chestnut brown }\end{array}$ & Gray-chestnut brown & Fawn & $\begin{array}{c}\text { Dark brown or blackish } \\
\text { brown }\end{array}$ \\
\hline \multicolumn{5}{|l|}{ Cranial characters } \\
\hline Condylobasal length & $61.5-74.9$ & $\sim 48.6$ & $59.0-64.1$ & $63.3-70.7$ \\
\hline Maxillary toothrow $\left(\mathrm{CM}^{2}\right)$ & $24.0-29.0$ & $19.0-19.2$ & $22.8-25.7$ & $24.6-27.9$ \\
\hline Mandibular toothrow $\left(\mathrm{CM}_{3}\right)$ & $25.6-33.0$ & $21.5-22.0$ & $25.7-28.6$ & $27.8-30.6$ \\
\hline Zygomatic breadth & $32.2-44.0$ & $\sim 28.0$ & $32.2-34.8$ & $32.9-40.2$ \\
\hline Mandible length & $47.8-60.0$ & $40.0-42.0$ & $48.9-53.2$ & $52.6-59.1$ \\
\hline
\end{tabular}

Note: All measurements are in mm; NA - Data not available 
Table 3.3. Diagnostic morphological characters of the two species of the genus Cynopterus Cuvier, F., 1824 present in South Asia

\begin{tabular}{|c|c|c|}
\hline Species & $\begin{array}{c}\text { Cynopterus sphinx } \\
\text { (Vahl, 1797) }\end{array}$ & $\begin{array}{l}\text { Cynopterus brachyotis } \\
\text { (Müller, 1838) }\end{array}$ \\
\hline \multicolumn{3}{|l|}{ External characters } \\
\hline Forearm length & $64.0-79.0$ & $57.3-63.3$ \\
\hline Head Body length & $76.0-113.0$ & $80.0-96.0$ \\
\hline Tail length & $4.5-19.0$ & $2.0-13.0$ \\
\hline Hind Foot length & $12.6-18.0$ & $11.0-15.0$ \\
\hline Ear length & $\begin{array}{l}17.5-24.0 \\
\text { Large with pale anterior and } \\
\text { posterior borders }\end{array}$ & $\begin{array}{l}14.5-18.0 \\
\text { Small with pale anterior and posterior } \\
\text { borders absent or poorly developed }\end{array}$ \\
\hline Metacarpals \& phalanges & Pale & Dark \\
\hline \multicolumn{3}{|l|}{ Cranial characters } \\
\hline Condylobasal length & $28.4-33.3$ & $26.0-28.8$ \\
\hline Maxillary toothrow $\left(\mathrm{CM}^{1}\right)$ & $10.2-12.2$ & $8.9-10.7$ \\
\hline Mandibular tooth row $\left(\mathrm{CM}_{2}\right)$ & $12.3-13.5$ & $10.0-11.9$ \\
\hline Zygomatic breadth & $18.8-23.1$ & $17.6-19.8$ \\
\hline Mandible length & $22.7-27.5$ & $20.5-23.8$ \\
\hline
\end{tabular}

Note: All measurements are in $\mathrm{mm}$

Table 3.4. Diagnostic morphological characters of the species of the genera Megaerops Peters, 1865; Latidens Thonlongya, 1972; Sphaerias Miller, 1906; Eonycteris Dobson, 1873; and Macroglossus Cuvier, F., 1824 present in South Asia

\begin{tabular}{|c|c|c|c|c|c|}
\hline Species & $\begin{array}{c}\text { Megaerops } \\
\text { niphanae } \\
\text { Yenbutra \& } \\
\text { Felten, } 1983\end{array}$ & $\begin{array}{c}\text { Latidens salimalii } \\
\text { Thonglongya, } \\
1972\end{array}$ & $\begin{array}{c}\text { Sphaerias } \\
\text { blanfordi } \\
\text { (Thomas, 1891) }\end{array}$ & $\begin{array}{c}\text { Eonycteris } \\
\text { spelaea } \\
\text { (Dobson, 1871) }\end{array}$ & $\begin{array}{c}\text { Macroglossus } \\
\text { sobrinus } \\
\text { (K. Andersen, } \\
\text { 1911) }\end{array}$ \\
\hline \multicolumn{6}{|l|}{ External characters } \\
\hline Forearm length & $52.0-63.0$ & $66.0-69.0$ & $51.7-60.5$ & $66.0-78.0$ & $44.0-52.0$ \\
\hline Head Body length & $81.0-90.0$ & $102.0-109.0$ & NA & $92.0-130.0$ & $78.0-89.0$ \\
\hline Tail length & Absent & Absent & Absent & $11.5-23.0$ & $\begin{array}{c}\text { Absent/ if present } \\
3.5-5.5\end{array}$ \\
\hline Hind Foot length & $\sim 14.0$ & $8.0-15.0$ & $\sim 12.0$ & $17.0-21.0$ & $\sim 10.0$ \\
\hline Ear length & $\begin{array}{l}18.5-19.0 \\
\text { Small, broadly } \\
\text { rounded }\end{array}$ & $\begin{array}{l}15.5-18.5 \\
\text { Oval, narrowly } \\
\text { rounded tip }\end{array}$ & $\begin{array}{c}16.1-19.5 \\
\text { Narrowly rounded } \\
\text { tip }\end{array}$ & $\begin{array}{c}16.9-21.0 \\
\text { Narrowly rounded } \\
\text { tip }\end{array}$ & $\begin{array}{l}15.0-17.0 \\
\text { Medium with } \\
\text { narrowly } \\
\text { rounded tips }\end{array}$ \\
\hline Interfemoral membrane & $\begin{array}{l}\text { Narrow, medial part } \\
\text { hairy }\end{array}$ & $\begin{array}{l}\text { Narrow, sparsely } \\
\text { haired } \\
\text { above and below }\end{array}$ & $\begin{array}{l}\text { Extremely narrow, } \\
\text { sparsely haired }\end{array}$ & $\begin{array}{l}\text { Moderately broad } \\
\text { sparsely haired } \\
\text { along the body }\end{array}$ & $\begin{array}{c}\text { Narrow, thickly } \\
\text { covered with short } \\
\text { hairs } \\
\text { above and below }\end{array}$ \\
\hline \multicolumn{6}{|l|}{ Cranial characters } \\
\hline Condylobasal length & $25.6-26.7$ & $31.4-33.0$ & $\sim 26.2$ & $31.7-36.3$ & $26.6-27.1$ \\
\hline Maxillary toothrow $\left(\mathrm{CM}^{1}\right)$ & $8.4-8.6$ & $11.3-11.8$ & $8.0-8.1$ & $11.9-13.4^{*}$ & $8.6-8.8^{*}$ \\
\hline Mandibular toothrow $\left(\mathrm{CM}_{3}\right)$ & $\sim 9.4$ & $12.4-12.9$ & $\sim 9.6$ & $13.0-13.7^{\dagger}$ & $9.7-10.1^{\dagger}$ \\
\hline Zygomatic breadth & $17.9-18.6$ & $21.0-22.1$ & $\sim 18.0$ & $19.0-22.1$ & $14.4-14.8$ \\
\hline Mandible length & $20.2-21.0$ & $24.8-26.3$ & $\sim 19.4$ & $25.1-28.8$ & $21.6-22.5$ \\
\hline
\end{tabular}

Note: All measurements are in $\mathrm{mm} ;{ }^{*}-\mathrm{CM}^{2} ;{ }^{\dagger}-\mathrm{CM}_{3}$ 


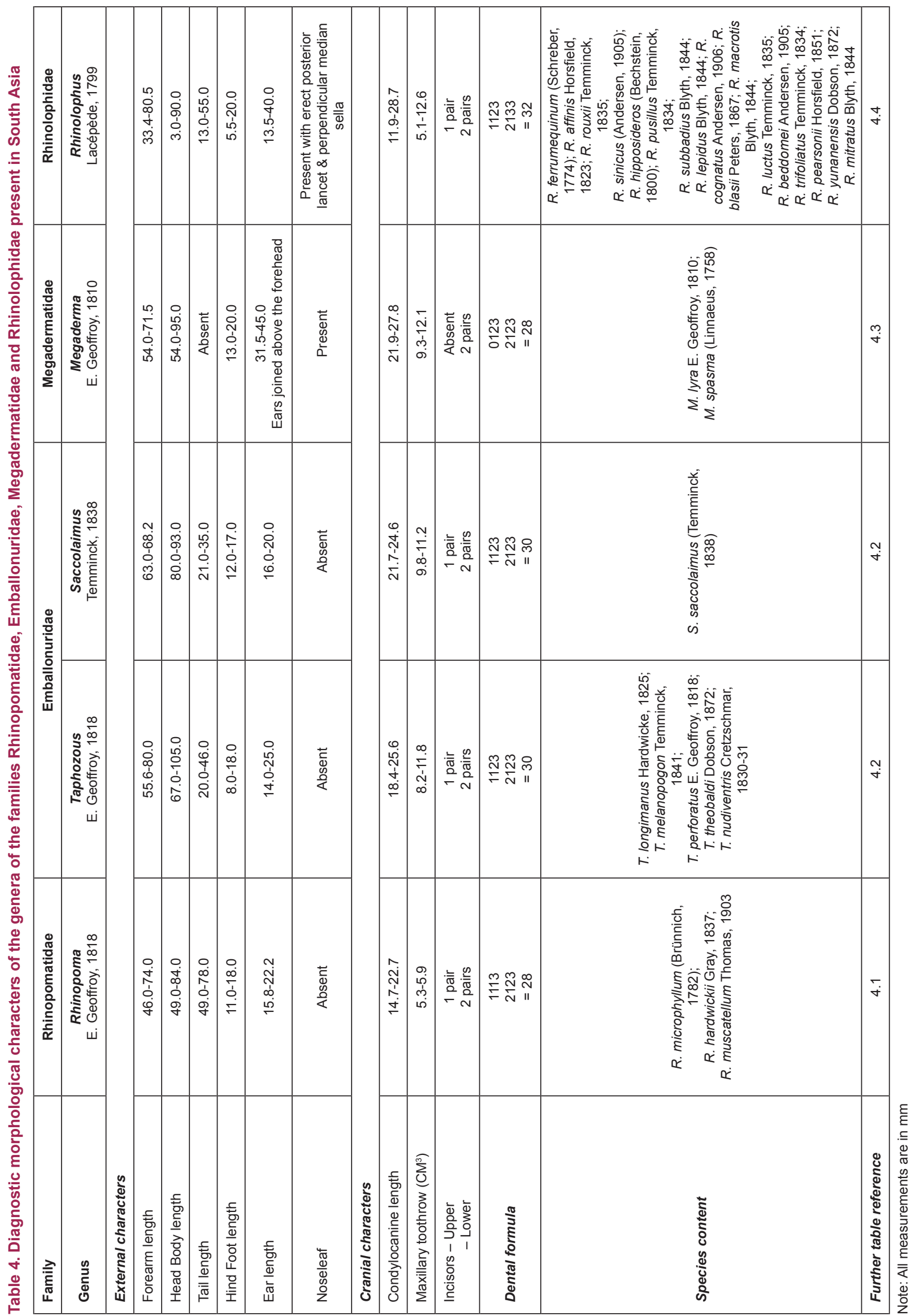


Table 4.1. Diagnostic morphological characters of the three species of the genus Rhinopoma E. Geoffroy, 1818 present in South Asia

\begin{tabular}{|c|c|c|c|}
\hline Species & $\begin{array}{c}\text { Rhinopoma microphyllum } \\
\text { (Brünnich, 1782) }\end{array}$ & $\begin{array}{c}\text { Rhinopoma hardwickii } \\
\text { Gray, } 1831\end{array}$ & $\begin{array}{c}\text { Rhinopoma muscatellum } \\
\text { Thomas, } 1903\end{array}$ \\
\hline \multicolumn{4}{|l|}{ External characters } \\
\hline Forearm length & $59.5-74.6$ & $52.9-64.0$ & $46.0-53.2$ \\
\hline Head Body length & $60.0-84.0$ & $55.0-73.0$ & $49.0-62.0$ \\
\hline Tail length & $50.0-77.0$ & $56.0-78.0$ & $49.0-64.3$ \\
\hline Hind Foot length & $14.0-18.0$ & $11.0-15.0$ & $11.0-13.0$ \\
\hline Ear length & $18.0-22.0$ & $17.0-21.0$ & $15.8-20.0$ \\
\hline Dermal ridge & Poorly developed & Well-developed & Poorly developed \\
\hline $\begin{array}{l}\text { Tail length in relation to } \\
\text { forearm length }\end{array}$ & Shorter & Longer & Longer \\
\hline \multicolumn{4}{|l|}{ Cranial characters } \\
\hline Condylocanine length & $17.2-22.7$ & $15.5-17.5$ & $14.7-15.1$ \\
\hline Maxillary toothrow $\left(\mathrm{CM}^{3}\right)$ & $7.0-8.0$ & $6.0-6.8$ & $5.3-5.9$ \\
\hline Mandibular tooth row $\left(\mathrm{CM}_{3}\right)$ & $7.6-8.6$ & $6.5-7.5$ & $5.1-6.7$ \\
\hline Zygomatic breadth & $11.4-13.4$ & $10.1-11.7$ & $8.8-9.8$ \\
\hline Mandible length & $13.7-15.8$ & $11.8-13.6$ & $10.5-11.4$ \\
\hline Nasal inflations & Small & Moderate & Large \\
\hline
\end{tabular}

Note: All measurements are in $\mathrm{mm}$

Table 4.3. Diagnostic morphological characters of the two species of the genus Megaderma E. Geoffroy, 1810 present in South Asia

\begin{tabular}{|c|c|c|}
\hline Species & $\begin{array}{l}\text { Megaderma lyra } \\
\text { E. Geoffroy, } 1810\end{array}$ & $\begin{array}{l}\text { Megaderma spasma } \\
\text { (Linnaeus, 1758) }\end{array}$ \\
\hline \multicolumn{3}{|l|}{ External characters } \\
\hline Forearm length & $56.0-71.5$ & $54.0-62.0$ \\
\hline Head Body length & $70.0-95.0$ & $54.0-81.0$ \\
\hline Tail length & Absent & Absent \\
\hline Hind Foot length & $14.0-20.0$ & $13.0-17.0$ \\
\hline Ear length & $\begin{array}{c}31.5-45.0 \\
\text { Oval with white inner margin, joined by } \\
\text { membrane over the forehead about } 1 / 3 \\
\text { to } 1 / 2 \text { of its length }\end{array}$ & $\begin{array}{l}33.0-40.0 \\
\text { Oval lacking white inner margin, } \\
\text { joined over the forehead near the base }\end{array}$ \\
\hline Tragus & Bifid with taller posterior process & $\begin{array}{l}\text { Bifid with narrower and taller posterior } \\
\text { process }\end{array}$ \\
\hline $\begin{array}{l}\text { Noseleaf } \\
\text { - sides } \\
\text { - longitudinal ridge } \\
\text { - base }\end{array}$ & $\begin{array}{c}\text { Tall }(\sim 10 \mathrm{~mm}) \\
\text { Straight } \\
\text { Present } \\
\text { Simple rounded horizontal }\end{array}$ & $\begin{array}{l}\text { Short }(\sim 6.5 \mathrm{~mm}) \\
\text { Convex } \\
\text { Present } \\
\text { Heart-shaped }\end{array}$ \\
\hline \multicolumn{3}{|l|}{ Cranial characters } \\
\hline Condylocanine length & $24.5-27.8$ & $21.9-23.6$ \\
\hline Maxillary toothrow $\left(\mathrm{CM}^{3}\right)$ & 10.6-12.1 & $9.3-10.5$ \\
\hline Mandibular toothrow $\left(\mathrm{CM}_{3}\right)$ & $11.6-12.2$ & $10.2-11.4$ \\
\hline Zygomatic breadth & $15.4-17.1$ & $13.6-14.8$ \\
\hline Mandible length & $18.8-21.2$ & $16.8-18.5$ \\
\hline
\end{tabular}

Note: All measurements are in $\mathrm{mm}$ 


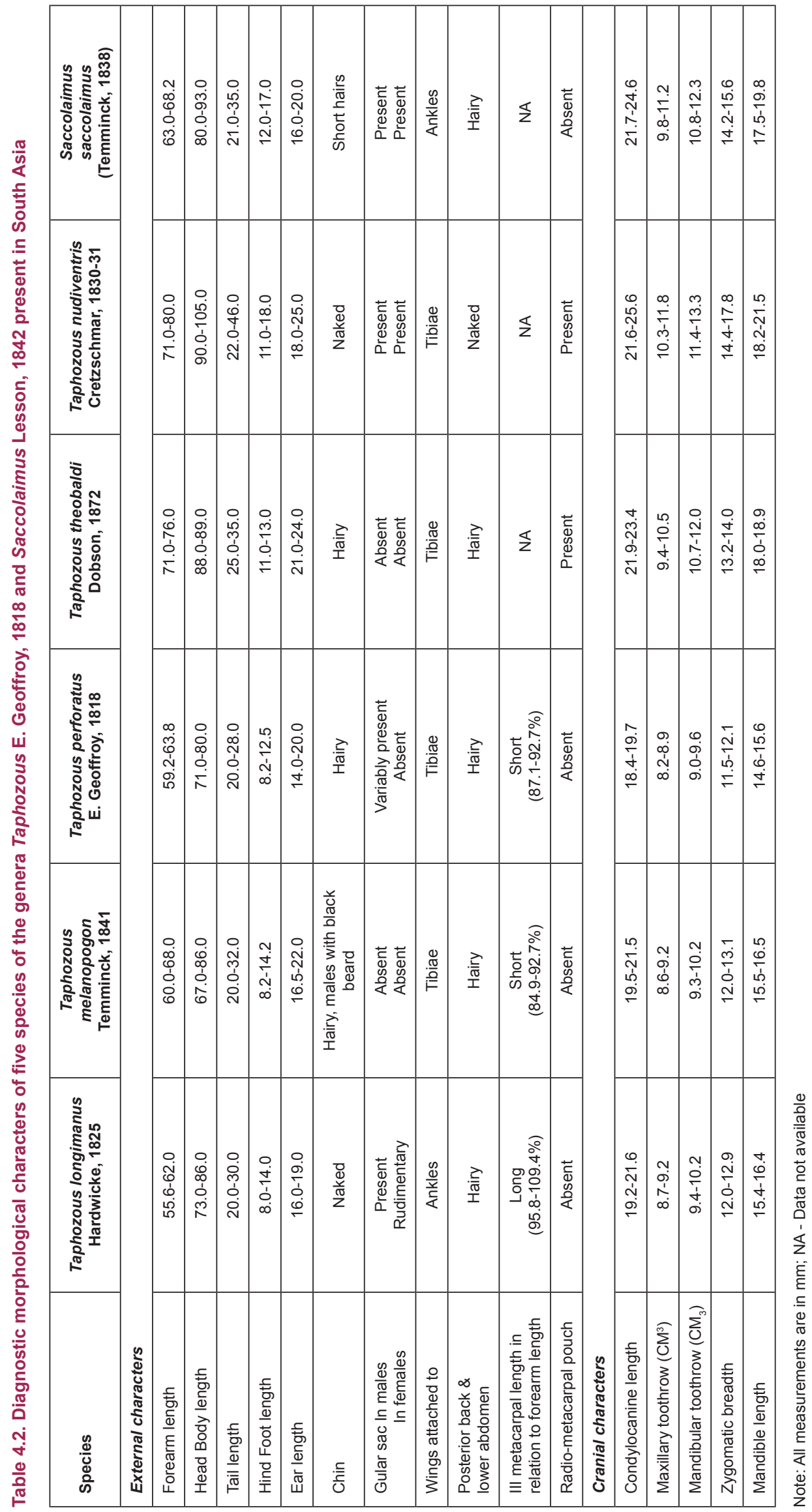




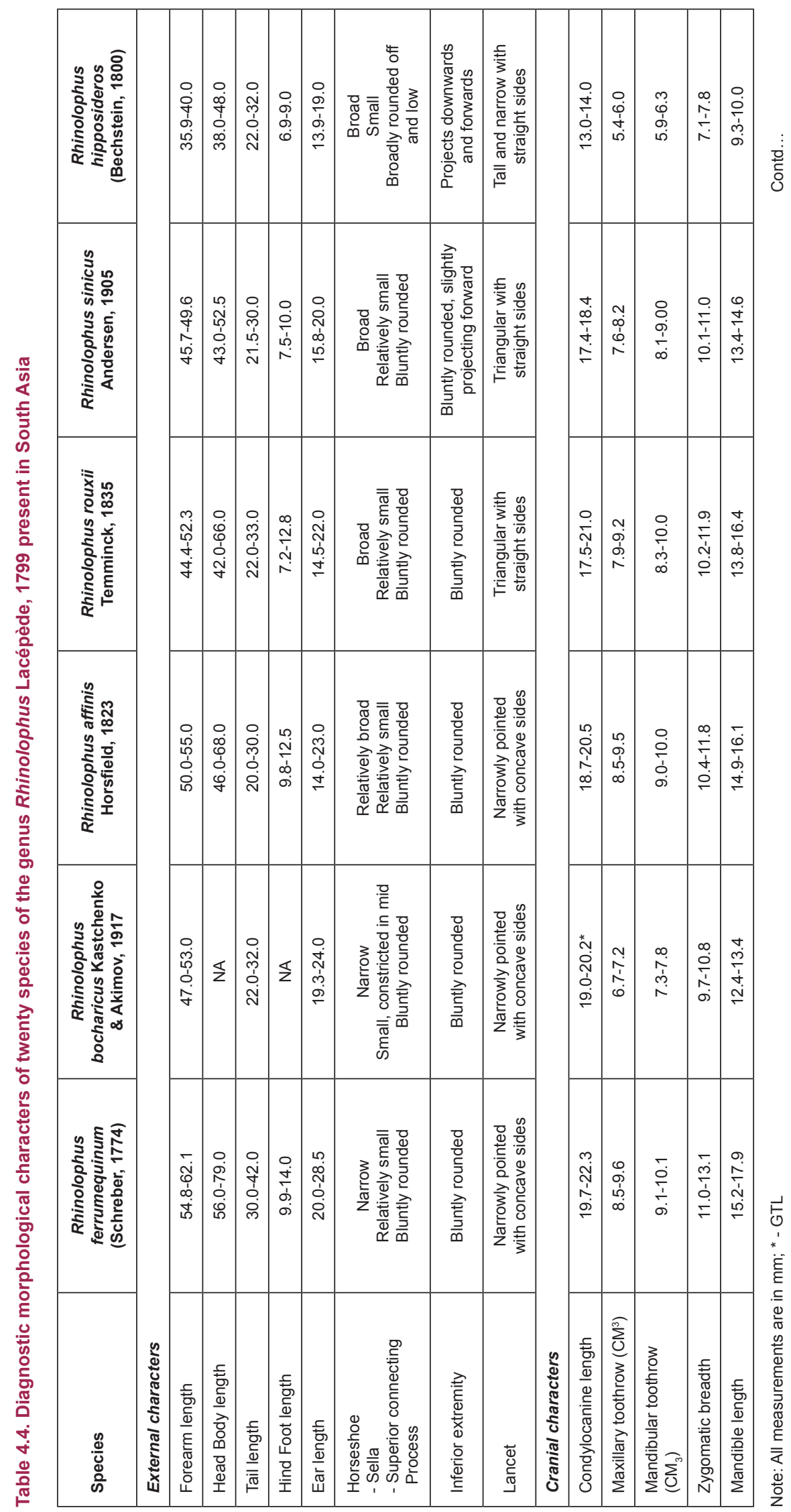




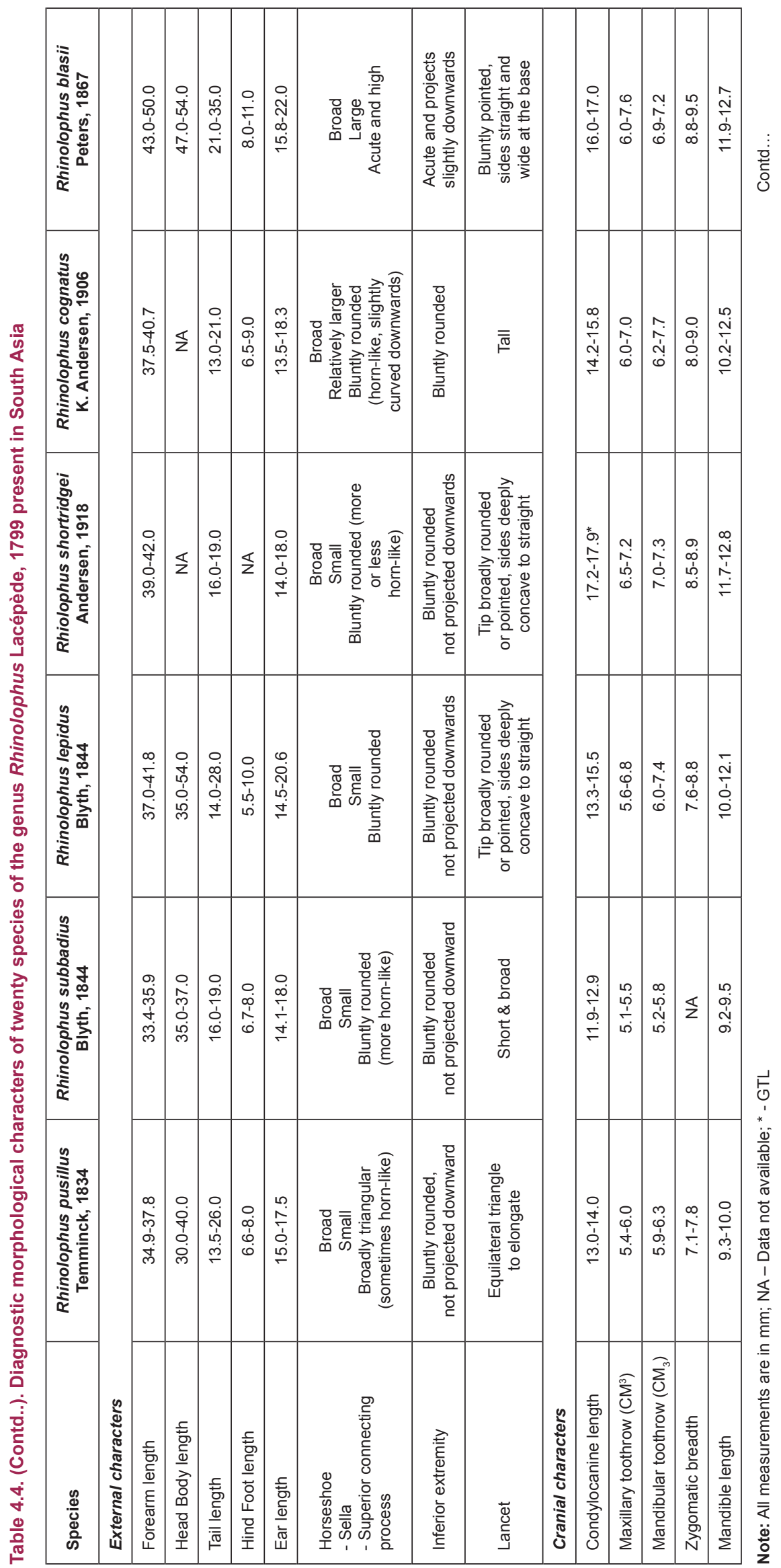




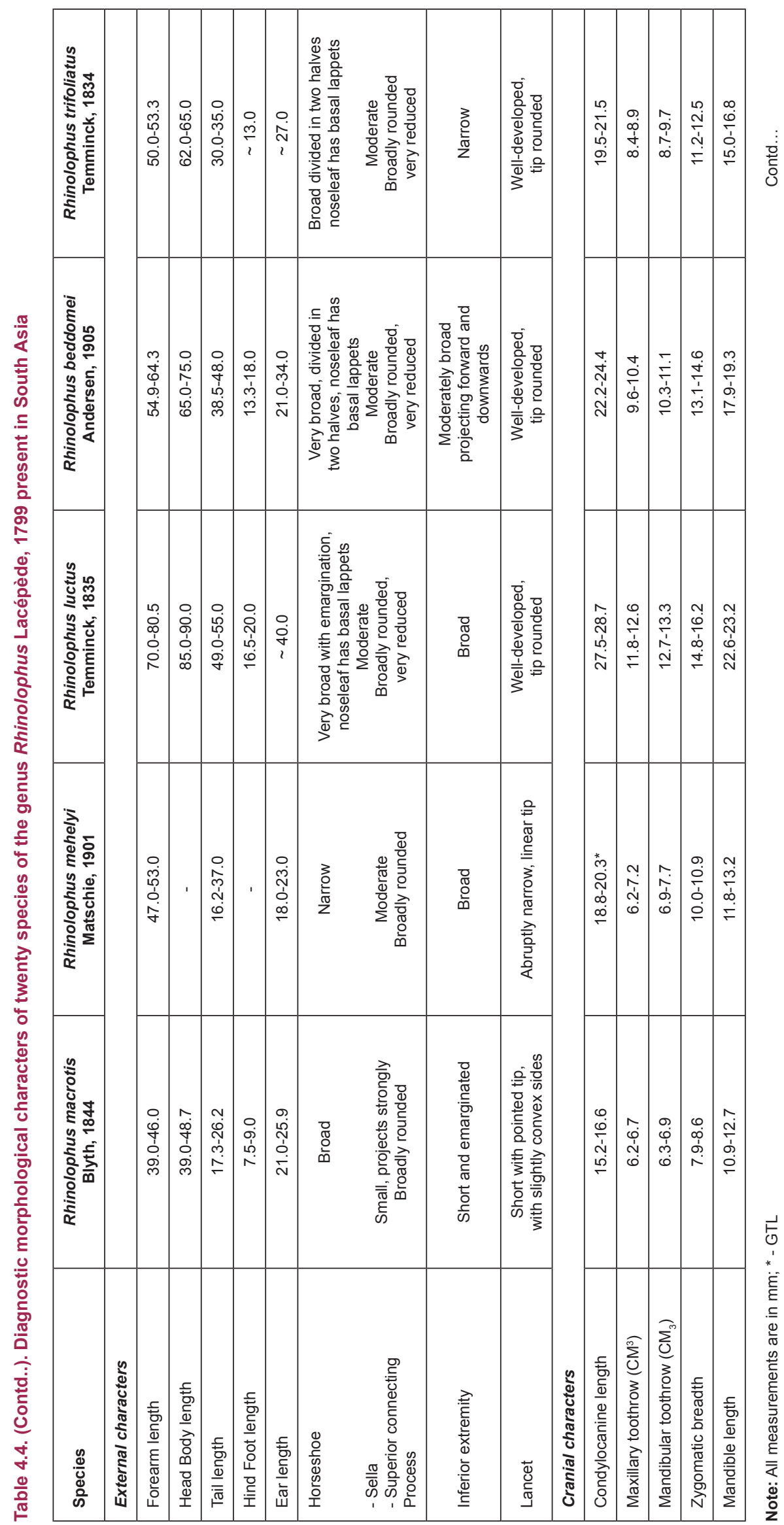


Table 4.4. (Contd..). Diagnostic morphological characters of twenty species of the genus Rhinolophus Lacépède, 1799 present in South Asia

\begin{tabular}{|c|c|c|c|}
\hline Species & $\begin{array}{l}\text { Rhinolophus pearsonii } \\
\text { Horsfield, } 1851\end{array}$ & $\begin{array}{c}\text { Rhinolophus yunanensis } \\
\text { Dobson, } 1872\end{array}$ & $\begin{array}{c}\text { Rhinolophus mitratus* } \\
\text { Blyth, } 1844\end{array}$ \\
\hline \multicolumn{4}{|l|}{ External characters } \\
\hline Forearm length & $50.8-54.8$ & $54.2-59.2$ & $\sim 57.1$ \\
\hline Head Body length & $51.0-64.0$ & $60.5-68.0$ & NA \\
\hline Tail length & $20.0-29.0$ & $21.5-26.0$ & $\sim 30.0$ \\
\hline Hind Foot length & $9.9-14.2$ & $12.5-14.0$ & NA \\
\hline Ear length & $23.5-28.0$ & $23.5-28.5$ & NA \\
\hline $\begin{array}{l}\text { Horseshoe } \\
\text { - Sella } \\
\text { - Superior connecting } \\
\text { process }\end{array}$ & $\begin{array}{c}\text { Broad } \\
\text { Moderate } \\
\text { Bluntly rounded }\end{array}$ & $\begin{array}{c}\text { Broad } \\
\text { Moderate } \\
\text { Bluntly rounded }\end{array}$ & $\begin{array}{c}\text { Broad } \\
\text { Moderate } \\
\text { Bluntly rounded }\end{array}$ \\
\hline Inferior extremity & $\begin{array}{l}\text { Not deflected downwards or } \\
\text { Forwards }\end{array}$ & $\begin{array}{l}\text { Not deflected downwards or } \\
\text { forwards }\end{array}$ & Narrow \\
\hline Lancet & $\begin{array}{l}\text { Well-developed } \\
\text { tip rounded }\end{array}$ & $\begin{array}{l}\text { Well-developed } \\
\text { tip rounded }\end{array}$ & $\begin{array}{l}\text { Well-developed } \\
\text { tip rounded }\end{array}$ \\
\hline \multicolumn{4}{|l|}{ Cranial characters } \\
\hline Condylocanine length & $19.7-22.3$ & $22.3-22.9$ & NA \\
\hline Maxillary toothrow $\left(\mathrm{CM}^{3}\right)$ & $8.5-9.6$ & $9.5-10.6$ & NA \\
\hline Mandibular toothrow $\left(\mathrm{CM}_{3}\right)$ & $9.1-10.1$ & $10.8-11.5$ & NA \\
\hline Zygomatic breadth & $11.0-13.1$ & $12.2-13.1$ & NA \\
\hline Mandible length & $15.2-17.9$ & $17.7-18.3$ & NA \\
\hline
\end{tabular}

Note: All measurements are in mm; * - Known only from type specimen with damaged skull; NA - Data not available 
Table 5. Diagnostic morphological characters of the genera of the family Hipposideridae present in South Asia

\begin{tabular}{|c|c|c|c|c|}
\hline Genus & $\begin{array}{c}\text { Hipposideros } \\
\text { Gray, } 1831\end{array}$ & $\begin{array}{c}\text { Triaenops } \\
\text { Dobson, } 1871\end{array}$ & $\begin{array}{c}\text { Asellia } \\
\text { Gray, } 1838\end{array}$ & $\begin{array}{c}\text { Coelops } \\
\text { Blyth, } 1848\end{array}$ \\
\hline \multicolumn{5}{|l|}{ External characters } \\
\hline Forearm length & $33.0-99.0$ & $48.3-54.0$ & $50.1-52.3$ & $37.8-42.0$ \\
\hline Head Body length & $38.0-106.0$ & $51.0-64.0$ & NA & NA \\
\hline Tail length & $20.0-64.0$ & $31.0-39.0$ & $25.0-28.0$ & Rudimentary ( $\left.c^{\prime} 2 \mathrm{~mm}\right)$ \\
\hline Hind Foot length & $5.3-20.0$ & $8.0-11.0$ & NA & NA \\
\hline Ear length & $13.0-34.0$ & $13.0-16.0$ & NA & NA \\
\hline Noseleaf & $\begin{array}{l}\text { Present with or without } \\
\text { supplementary leaflets }\end{array}$ & $\begin{array}{l}\text { Present with single pair } \\
\text { of supplementary leaflets }\end{array}$ & $\begin{array}{l}\text { Present with two pairs } \\
\text { of supplementary leaflets }\end{array}$ & $\begin{array}{c}\text { Present with two } \\
\text { elongated } \\
\text { supplementary lappets }\end{array}$ \\
\hline Interfemoral membrane & Wide & Wide & Wide & Narrow \\
\hline \multicolumn{5}{|l|}{ Cranial characters } \\
\hline Condylocanine length & $12.7-31.5$ & $16.9-18.9^{*}$ & $15.7-17.0$ & $14.3-14.8$ \\
\hline Maxillary toothrow $\left(\mathrm{CM}^{3}\right)$ & $4.9-14.5$ & 6.1-7.1 & $6.5-7.2$ & $5.8-6.0$ \\
\hline $\begin{array}{r}\text { Incisors - Upper } \\
\text { - Lower }\end{array}$ & $\begin{array}{l}1 \text { pair } \\
2 \text { pairs }\end{array}$ & $\begin{array}{l}1 \text { pair } \\
2 \text { pairs }\end{array}$ & $\begin{array}{l}1 \text { pair } \\
2 \text { pairs }\end{array}$ & $\begin{array}{l}1 \text { pair } \\
2 \text { pairs }\end{array}$ \\
\hline Dental formula & $\begin{array}{l}1123 \\
2123 \\
=30\end{array}$ & $\begin{array}{l}1123 \\
2123 \\
=30\end{array}$ & $\begin{array}{l}1113 \\
2123 \\
=28\end{array}$ & $\begin{array}{l}1123 \\
2123 \\
=30\end{array}$ \\
\hline Species content & $\begin{array}{l}\text { H. ater, Templeton, 1848; } \\
\text { H. cineraceus Blyth, 1853; } \\
\text { H. durgadasi Khajuria, 1970; } \\
\text { H. fulvus Gray, 1838; } \\
\text { H. pomona K. Andersen, } \\
\text { 1918; H. hypophyllus } \\
\text { Kock \& Bhat, 1994; H. } \\
\text { galeritus Cantor, 1846; H. } \\
\text { speoris (Schneider, 1800); } \\
\text { H. larvatus (Horsfield, } \\
\text { 1823); H. armiger Hodgson, } \\
\text { 1835; H. lankadiva Kelaart, } \\
\text { 1850; H. diadema Geoffroy, } \\
\text { E., } 1813\end{array}$ & $\begin{array}{l}\text { T. persicus Dobson, } \\
1871\end{array}$ & $\begin{array}{c}\text { A. tridens Geoffroy, E., } \\
1813\end{array}$ & C. frithii Blyth, 1848 \\
\hline Further table reference & 5.1 & 5.2 & 5.2 & 5.2 \\
\hline
\end{tabular}

Note: All measurements are in mm; * - Condylobasal length; NA - Data not available 


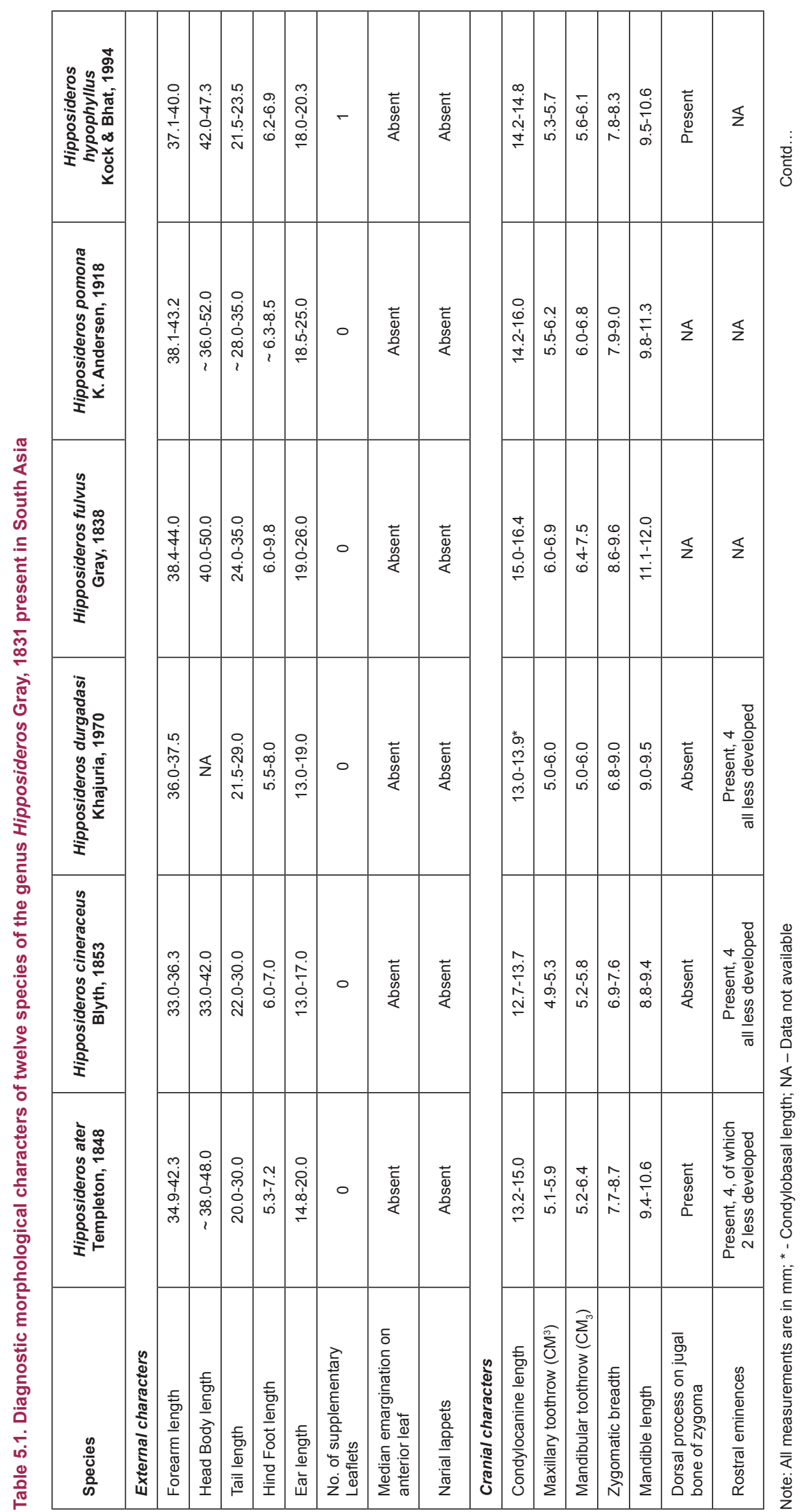




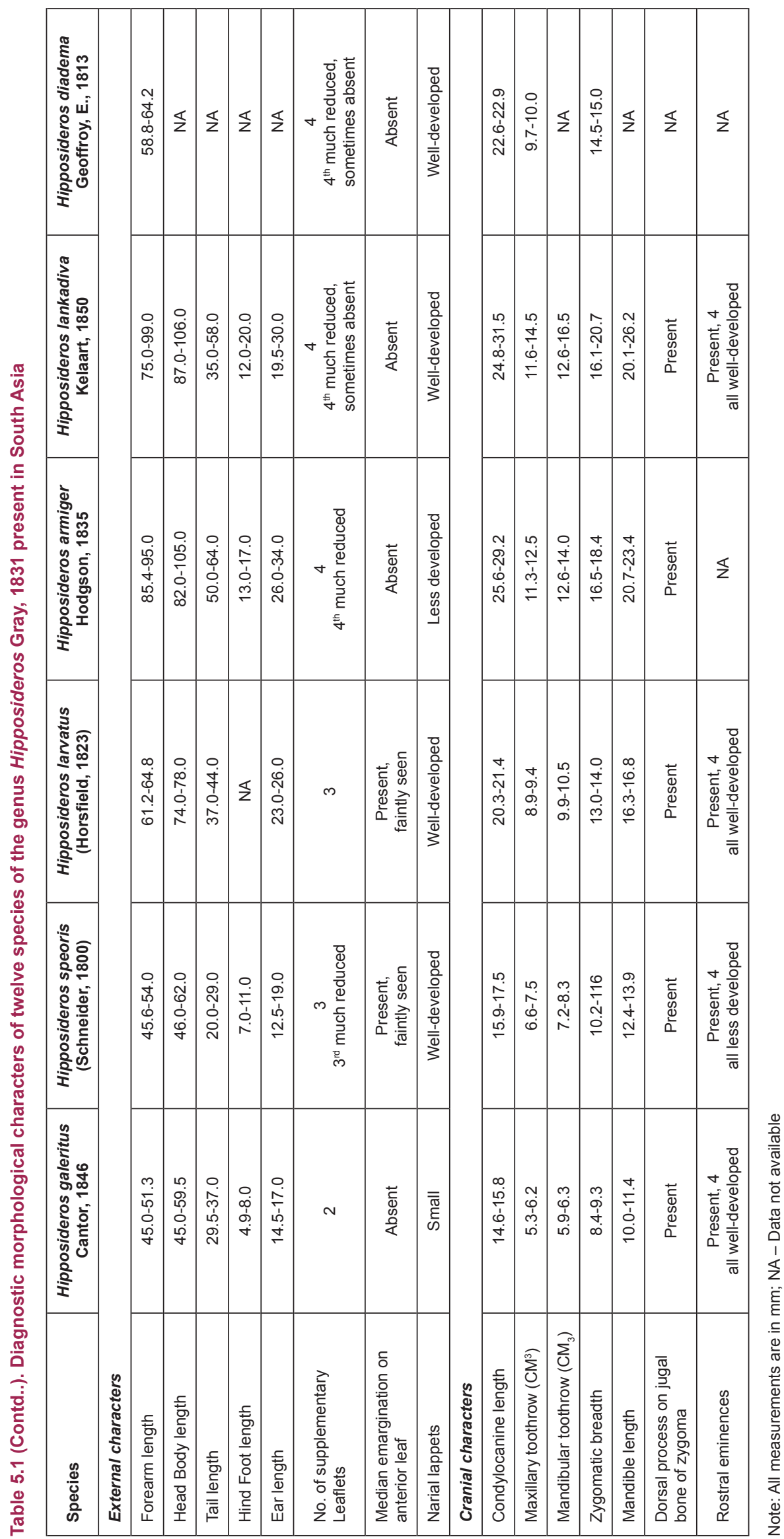


Table 5.2. Diagnostic morphological characters of one species each of the genera Triaenops Dobson, 1871; Asellia Gray, 1838; and Coelops Blyth, 1848 present in South Asia

\begin{tabular}{|c|c|c|c|}
\hline Species & $\begin{array}{l}\text { Triaenops persicus } \\
\text { Dobson, } 1871\end{array}$ & $\begin{array}{c}\text { Asellia tridens } \\
\text { Geoffroy, E., } 1813\end{array}$ & $\begin{array}{l}\text { Coelops frithii } \\
\text { Blyth, } 1848\end{array}$ \\
\hline \multicolumn{4}{|l|}{ External characters } \\
\hline Forearm length & $48.3-54.0$ & $50.1-52.3$ & $37.8-42.0$ \\
\hline Head Body length & $51.0-64.0$ & $52.0-55.0$ & $38.0-50.0$ \\
\hline Tail length & $31.0-39.0$ & $25.0-28.0$ & Rudimentary, $<2.0$ \\
\hline Hind Foot length & $8.0-11.0$ & $9.0-10.0$ & $5.3-9.0$ \\
\hline Ear length & $\begin{array}{c}11.0-16.0 \\
\text { Small, funnel-shaped }\end{array}$ & $\begin{array}{c}19.0-20.0 \\
\text { Broad with pointed tips }\end{array}$ & $\begin{array}{c}11.5-15.0 \\
\text { Broad with rounded tip }\end{array}$ \\
\hline Noseleaf & $\begin{array}{l}\text { Complex with three vertical } \\
\text { pointed processes }\end{array}$ & $\begin{array}{l}\text { Complex with three vertical } \\
\text { processes, central one pointed, } \\
\text { others blunt }\end{array}$ & $\begin{array}{l}\text { Complex with anterior leaf } \\
\text { divided in to two and with } \\
\text { forwardly projecting } \\
\text { supplementary lappets }\end{array}$ \\
\hline No. of supplementary leaflets & 1 & 2 & 0 \\
\hline $\begin{array}{l}\text { Median emargination on anterior } \\
\text { leaf }\end{array}$ & Deep & Absent & Deep \\
\hline Narial lappets & Well-developed & Less developed & Well-developed \\
\hline \multicolumn{4}{|l|}{ Cranial characters } \\
\hline Condylocanine length & $16.9-18.9^{*}$ & $15.7-17.0$ & $14.3-14.8$ \\
\hline Maxillary toothrow $\left(\mathrm{CM}^{3}\right)$ & $6.1-7.1$ & $6.5-7.2$ & $5.8-6.0$ \\
\hline Mandibular toothrow $\left(\mathrm{CM}_{3}\right)$ & $7.0-7.7$ & 7.3-8.3 & $6.0-6.5$ \\
\hline Zygomatic breadth & $8.7-9.5$ & $9.7-10.7$ & $7.2-7.5$ \\
\hline Mandible length & $11.7-13.1$ & $12.2-13.2$ & $9.8-10.2$ \\
\hline $\begin{array}{l}\text { Dorsal process on jugal bone of } \\
\text { zygoma }\end{array}$ & Present & Present, less developed & Absent \\
\hline Rostral eminences & Present, 4, all well-developed & Present, 4, all well-developed & Present, 4 , all less developed \\
\hline
\end{tabular}

Note: All measurements are in mm; * - Condylobasal length; NA - Data not available 
Table 6. Diagnostic morphological characters of the genera of the family Molossidae present in South Asia

\begin{tabular}{|c|c|c|c|}
\hline Genus & Tadarida Rafinesque, 1814 & Chaerephon Dobson, 1874 & Otomops Thomas, 1913 \\
\hline \multicolumn{4}{|l|}{ External characters } \\
\hline Forearm length & $46.0-63.9$ & $43.1-50.2$ & $63.0-67.0$ \\
\hline Head Body length & $61.0-90.0$ & $66.0-71.0$ & $87.0-99.0$ \\
\hline Tail length & $33.0-60.0$ & $30.0-44.0$ & $41.0-49.0$ \\
\hline Hind Foot length & $7.0-12.1$ & $9.0-11.3$ & $10.0-14.0$ \\
\hline Ear length & $\begin{array}{l}15.0-32.0 \\
\text { Not joined over forehead }\end{array}$ & $\begin{array}{c}16.0-21.0 \\
\text { Joined by membrane over } \\
\text { forehead }\end{array}$ & $\begin{array}{c}31.2-34.0 \\
\text { Joined by membrane over } \\
\text { forehead }\end{array}$ \\
\hline \multicolumn{4}{|l|}{ Cranial characters } \\
\hline Condylocanine length & $17.1-23.1$ & $15.9-17.1$ & $21.8-23.2$ \\
\hline Maxillary toothrow $\left(\mathrm{CM}^{3}\right)$ & 7.1-9.3 & $6.4-7.3$ & $8.8-9.3$ \\
\hline $\begin{array}{r}\text { Incisors - Upper } \\
\text { - Lower }\end{array}$ & $\begin{array}{c}1 \text { pair } \\
2 / 3 \text { pairs }\end{array}$ & $\begin{array}{l}1 \text { pair } \\
2 \text { pairs }\end{array}$ & $\begin{array}{c}1 \text { pair } \\
2 / 3 \text { pairs }\end{array}$ \\
\hline Dental formula & $\begin{array}{c}1123 \\
2(3) 123 \\
=30 / 32\end{array}$ & $\begin{array}{l}1123 \\
2123 \\
=30\end{array}$ & $\begin{array}{c}1123 \\
2(3) 123 \\
=30 / 32\end{array}$ \\
\hline Species content & $\begin{array}{l}\text { T. teniotis (Rafinesque, 1814); } \\
\text { T. aegyptiaca (E. Geoffroy, 1818) }\end{array}$ & C. plicatus (Buchanan, 1800) & O. wroughtoni Thomas, 1913 \\
\hline Further table reference & 6.1 & 6.1 & 6.1 \\
\hline
\end{tabular}

Note: All measurements are in $\mathrm{mm}$

Table 6.1. Diagnostic morphological characters of the species of the genera Tadarida Rafinesque, 1814, Chaerephon Dobson, 1874 and Otomops Thomas, 1913 present in South Asia

\begin{tabular}{|c|c|c|c|c|}
\hline Genus & $\begin{array}{l}\text { Tadarida teniotis } \\
\text { (Rafinesque, 1814) }\end{array}$ & $\begin{array}{c}\text { Tadarida aegyptiaca } \\
\text { (E. Geoffroy, 1818) }\end{array}$ & $\begin{array}{l}\text { Chaerephon plicatus } \\
\text { (Buchanan, 1800) }\end{array}$ & $\begin{array}{l}\text { Otomops wroughtoni } \\
\text { Thomas, } 1913\end{array}$ \\
\hline \multicolumn{5}{|l|}{ External characters } \\
\hline Forearm length & $58.4-63.9$ & $46.0-52.3$ & $43.1-50.2$ & $63.0-67.0$ \\
\hline Head Body length & $74.0-90.0$ & $61.0-77.0$ & $66.0-71.0$ & $87.0-99.0$ \\
\hline Tail length & $43.0-54.8$ & $33.0-60.0$ & $30.0-44.0$ & $41.0-49.0$ \\
\hline Hind Foot length & $9.0-12.1$ & $7.0-10.0$ & $9.0-11.3$ & $10.0-14.0$ \\
\hline Ear length & $\begin{array}{c}25.0-32.0 \\
\text { Not joined over forehead }\end{array}$ & $\begin{array}{c}15.0-23.0 \\
\text { Not joined over forehead }\end{array}$ & $\begin{array}{l}\text { 16.0-21.0 } \\
\text { Joined over forehead by a } \\
\text { membrane }\end{array}$ & $\begin{array}{l}\text { 31.2-34.0 } \\
\text { Joined over forehead by } \\
\text { a membrane }\end{array}$ \\
\hline Antitragus & Large & Small & Small & Absent \\
\hline \multicolumn{5}{|l|}{ Cranial characters } \\
\hline Condylocanine length & $21.6-23.1$ & $17.1-18.8$ & $15.9-17.1$ & $21.8-23.2$ \\
\hline Maxillary toothrow $\left(\mathrm{CM}^{3}\right)$ & $8.2-9.3$ & $7.1-7.8$ & $6.4-7.3$ & $8.8-9.3$ \\
\hline Mandibular toothrow $\left(\mathrm{CM}_{3}\right)$ & $9.1-9.8$ & $7.7-8.6$ & $6.9-7.9$ & $9.2-9.8$ \\
\hline Zygomatic breadth & $13.4-14.2$ & $11.3-13.3$ & $10.9-11.4$ & $12.6-13.3$ \\
\hline Mandible length & $16.6-17.5$ & $13.3-14.6$ & $11.8-13.4$ & $15.9-16.9$ \\
\hline Lower Incisors & 3 pairs & 2 pairs & 2 pairs & 2/3 pairs \\
\hline
\end{tabular}

Note: All measurements are in $\mathrm{mm}$ 
Table 7. Diagnostic morphological characters of the genera of the subfamilies Murininae, Kerivoulinae and Myotinae of family Vespertilionidae present in South Asia

\begin{tabular}{|c|c|c|c|c|c|}
\hline Genus & $\begin{array}{c}\text { Murina } \\
\text { Gray, } 1842\end{array}$ & $\begin{array}{c}\text { Harpiola } \\
\text { Thomas, } 1915\end{array}$ & $\begin{array}{c}\text { Harpiocephalus } \\
\text { Gray, } 1842\end{array}$ & $\begin{array}{l}\text { Kerivoula } \\
\text { Gray, } 1842\end{array}$ & $\begin{array}{c}\text { Myotis } \\
\text { Kaup, } 1829\end{array}$ \\
\hline \multicolumn{6}{|l|}{ External characters } \\
\hline Forearm length & $27.7-40.9$ & $32.4-34.2$ & $44.1-50.1$ & $31.5-42.0$ & $30.0-58.3$ \\
\hline Head Body length & $38.0-50.0$ & $35.6-42.7$ & $60.0-75.0$ & $39.0-55.0$ & $38.0-80.0$ \\
\hline Tail length & $27.0-41.0$ & 27.5 & $40.0-50.0$ & $35.0-55.0$ & $25.0-68.0$ \\
\hline Hind Foot length & $4.5-10.0$ & 8.2 & $11.0-14.0$ & $4.0-9.0$ & $6.7-17.0$ \\
\hline Ear length & $\begin{array}{c}13.0-17.0 \\
\text { Short, broad and } \\
\text { tip rounded }\end{array}$ & $\begin{array}{c}12.1 \\
\text { Short, broad, } \\
\text { triangular and } \\
\text { tip rounded }\end{array}$ & $\begin{array}{l}17.0-18.0 \\
\text { Rounded }\end{array}$ & $\begin{array}{c}11.0-17.0 \\
\text { Moderately long } \\
\text { and } \\
\text { funnel shaped }\end{array}$ & $\begin{array}{c}6.0-19.0 \\
\text { Narrow and tip } \\
\text { bluntly rounded }\end{array}$ \\
\hline \multicolumn{6}{|l|}{ Cranial characters } \\
\hline Condylocanine length & $12.1-16.3$ & $12.1-14.8$ & $19.0-19.5$ & $12.2-15.9$ & $11.2-18.9$ \\
\hline Maxillary toothrow $\left(\mathrm{CM}^{3}\right)$ & $4.5-6.1$ & $4.9-5.3$ & $6.5-6.9$ & $5.5-7.4$ & $4.5-8.5$ \\
\hline $\begin{array}{r}\text { Incisors - Upper } \\
\text { - Lower }\end{array}$ & $\begin{array}{l}2 \text { pairs } \\
3 \text { pairs }\end{array}$ & $\begin{array}{l}2 \text { pairs } \\
3 \text { pairs }\end{array}$ & $\begin{array}{l}2 \text { pairs } \\
3 \text { pairs }\end{array}$ & $\begin{array}{l}2 \text { pairs } \\
3 \text { pairs }\end{array}$ & $\begin{array}{l}2 \text { pairs } \\
3 \text { pairs } \\
\end{array}$ \\
\hline $\begin{array}{r}\text { Premolars - Upper } \\
\text { - Lower }\end{array}$ & $\begin{array}{l}2 \text { pairs } \\
2 \text { pairs }\end{array}$ & $\begin{array}{l}2 \text { pairs } \\
2 \text { pairs }\end{array}$ & $\begin{array}{l}2 \text { pairs } \\
2 \text { pairs }\end{array}$ & $\begin{array}{l}3 \text { pairs } \\
3 \text { pairs }\end{array}$ & $\begin{array}{l}2-3 \text { pairs } \\
2-3 \text { pairs }\end{array}$ \\
\hline Dental formula & $\begin{array}{c}-23,1,-2-4,123 \\
123,1,-2-4,123 \\
=34\end{array}$ & $\begin{array}{c}-23,1,-2-4,123 \\
123,1,-2-4,123 \\
=34\end{array}$ & $\begin{array}{c}-23,1,-2-4,123 \\
123,1,-2-4,123 \\
=34\end{array}$ & $\begin{array}{c}-23,1,-234,123 \\
123,1,-234,123 \\
=38\end{array}$ & $\begin{array}{c}213(2) 3 \\
313(2) 3 \\
=38 / 34\end{array}$ \\
\hline Species content & $\begin{array}{c}\text { M. leucogaster } \\
\text { Milne-Edwards, } \\
1872 ; \\
\text { M. aurata } \\
\text { Milne-Edwards, } \\
1872 ; \\
\text { M. cyclotis } \\
\text { Dobson, 1872; } \\
\text { M. tubinaris } \\
\text { (Scully, 1881); } \\
\text { M. huttoni } \\
\text { (Peters, 1872); }\end{array}$ & $\begin{array}{c}\text { H. grisea } \\
\text { (Peters, 1872) }\end{array}$ & $\begin{array}{c}\text { H. harpia } \\
\text { (Temminck, 1840) }\end{array}$ & $\begin{array}{c}\text { K. picta } \\
\text { (Pallas, 1767); } \\
\text { K. hardwickii } \\
\text { (Horsfield, 1825); } \\
\text { K. lenis } \\
\text { Thomas, } 1916\end{array}$ & $\begin{array}{c}\text { M. blythii } \\
\text { (Tomes, 1857); } \\
\text { M. sicarius } \\
\text { Thomas, 1915; } \\
\text { M. formosus } \\
\text { (Hodgson, 1835); } \\
\text { M. nipalensis } \\
\text { (Dobson, 1871); } \\
\text { M. muricola } \\
\text { (Gray, 1846); } \\
\text { M. siligorensis } \\
\text { (Horsfield, 1855); } \\
\text { M. montivagus } \\
\text { (Dobson, 1874); M. } \\
\text { annectans (Dobson, 1871); } \\
\text { M. longipes (Dobson, 1873); } \\
\text { M. laniger (Peters, 1871); M. } \\
\text { csorbai Topal, 1997; } \\
\text { M horsfieldii (Temminck, } \\
\text { 1814); M. hasseltii } \\
\text { (Temminck, 1840) }\end{array}$ \\
\hline Further table reference & 7.1 & 7.1 & 7.1 & 7.2 & 7.3 \\
\hline
\end{tabular}




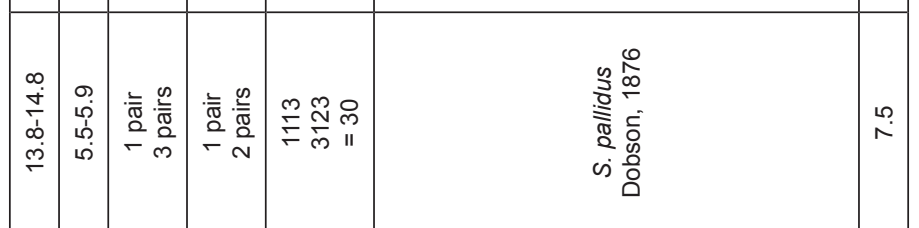

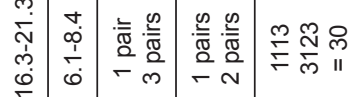

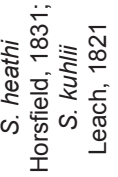

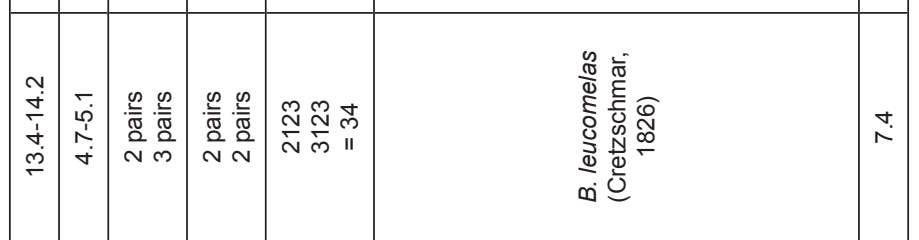




\begin{tabular}{|c|c|c|c|c|c|c|c|c|c|c|c|c|c|c|}
\hline 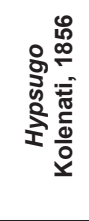 & & 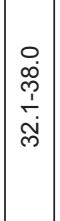 & \begin{tabular}{l|l}
0 \\
$\dot{0}$ \\
$\vdots$ \\
$\dot{\sigma}$ \\
$\dot{\sigma}$
\end{tabular} & $\mid \begin{array}{l}0 \\
0 \\
o \\
0 \\
0 \\
\dot{m}\end{array}$ & $\begin{array}{l}0 \\
0 \\
0 \\
+ \\
0\end{array}$ & $\begin{array}{l}0 \\
\stackrel{\rho}{\rho} \\
\grave{0} \\
\stackrel{0}{\circ}\end{array}$ & & & 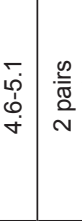 & 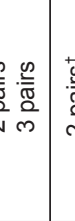 & 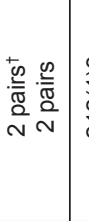 & 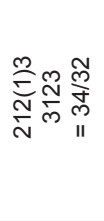 & 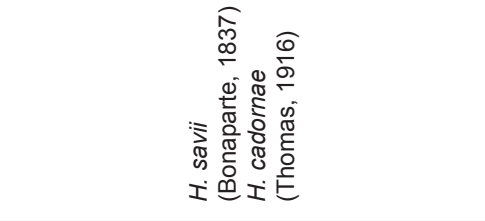 & $\stackrel{\infty}{\stackrel{\infty}{\sim}}$ \\
\hline 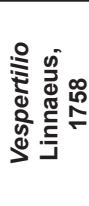 & & 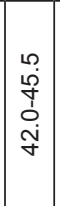 & \begin{tabular}{l|l}
0 & \\
0 \\
0 \\
0 \\
$\dot{\leftrightarrow}$ \\
$\dot{\omega}$
\end{tabular} & $\mid \begin{array}{l}0 \\
0 \\
o \\
0 \\
0 \\
\dot{q} \\
\dot{y} \\
\mid\end{array}$ & $\begin{array}{l}0 \\
0 \\
\grave{1} \\
\vdots \\
\infty \\
\infty\end{array}$ & 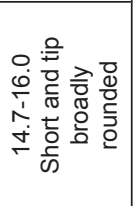 & & \begin{tabular}{c|c}
0 & 5 \\
$i b$ & 5 \\
$i$ & 0 \\
$i$ & 0
\end{tabular} & 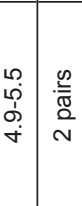 & 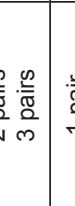 & 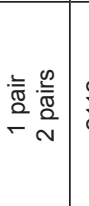 & 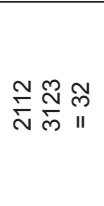 & 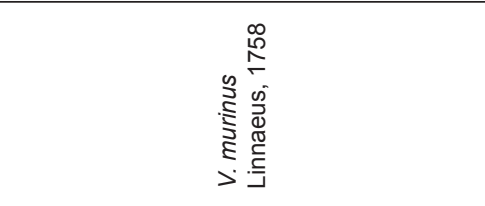 & \begin{tabular}{|l|}
$\stackrel{\infty}{\sim}$ \\
$\stackrel{1}{*}$
\end{tabular} \\
\hline 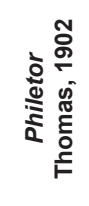 & & 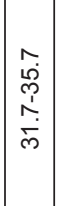 & $\S$ & 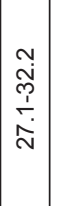 & 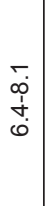 & 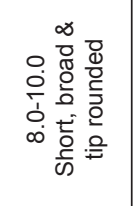 & & 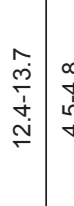 & & 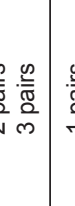 & 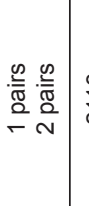 & 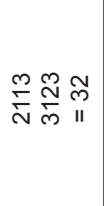 & 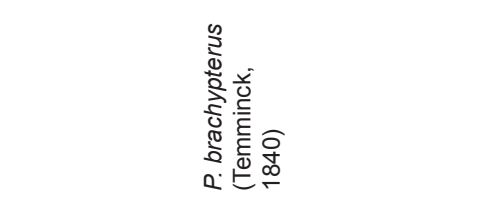 & $\stackrel{\infty}{\sim}$ \\
\hline 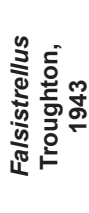 & & 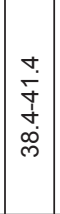 & \begin{tabular}{|l|} 
\\
$\dot{L}$ \\
$\dot{p}$ \\
0 \\
$\dot{g}$
\end{tabular} & $\mid \begin{array}{l}0 \\
\dot{\dot{q}} \\
\dot{0} \\
\dot{m} \\
\end{array}$ & $\begin{array}{l}0 \\
0 \\
0 \\
0 \\
\\
\end{array}$ & 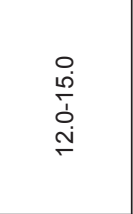 & & 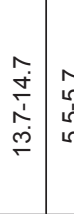 & & 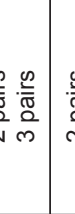 & 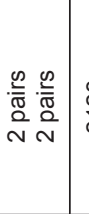 & 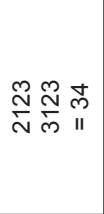 & 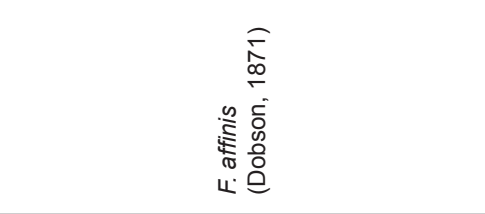 & 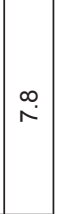 \\
\hline 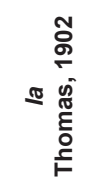 & & 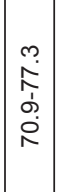 & $\mathbb{z}$ & $\mid \begin{array}{l}0 \\
\dot{0} \\
0 \\
1\end{array}$ & $\begin{array}{l}\stackrel{0}{\hat{T}} \\
i\end{array}$ & 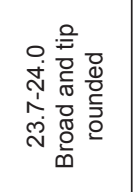 & & 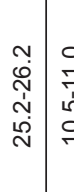 & 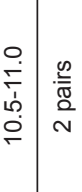 & 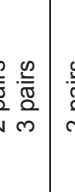 & 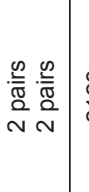 & ָָ ָ & 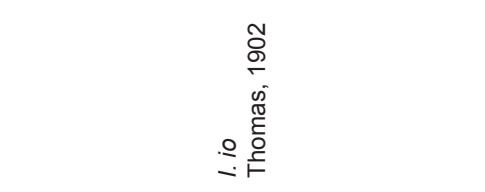 & $\stackrel{\infty}{\stackrel{\infty}{\sim}}$ \\
\hline 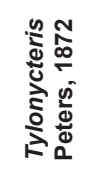 & & 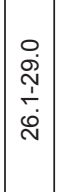 & $\mid \begin{array}{l}0 \\
0 \\
\dot{0} \\
0 \\
\dot{m} \\
\dot{m} \\
\end{array}$ & $\mid \begin{array}{l}0 \\
\ddot{m} \\
\dot{d} \\
\dot{i} \\
\dot{i}\end{array}$ & $\begin{array}{l}0 \\
\dot{\hat{j}} \\
\dot{\phi} \\
i\end{array}$ & 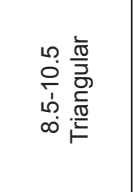 & & 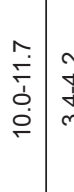 & 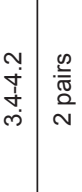 & 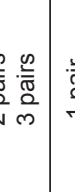 & 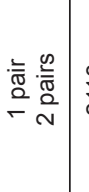 & 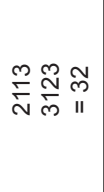 & 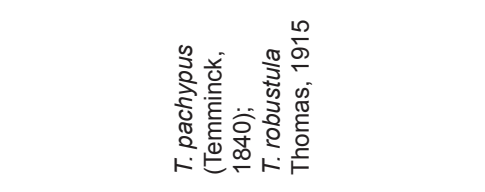 & \begin{tabular}{|l|}
$\stackrel{\infty}{\sim}$ \\
$\stackrel{1}{*}$
\end{tabular} \\
\hline 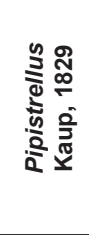 & & 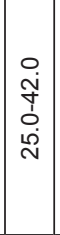 & \begin{tabular}{|l|}
0 \\
0 \\
0 \\
0 \\
0 \\
$\tilde{p}$ \\
\end{tabular} & $\mid \begin{array}{l}0 \\
\dot{j} \\
0 \\
0 \\
\dot{i} \\
\end{array}$ & 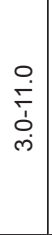 & $\begin{array}{l}\stackrel{0}{\dot{+}} \\
\stackrel{+}{\dot{d}} \\
\text { iे }\end{array}$ & & 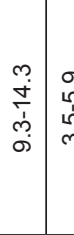 & 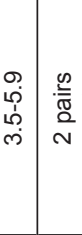 & 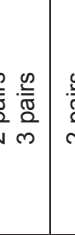 & 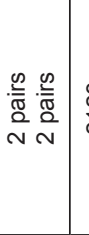 & 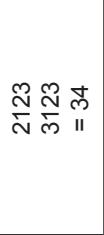 & 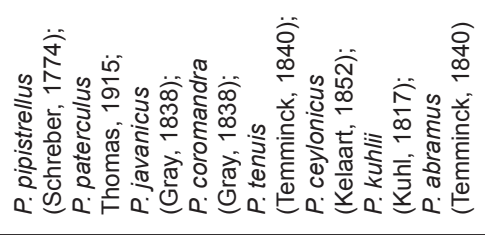 & $\hat{r}$ \\
\hline 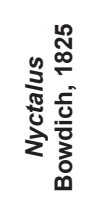 & & 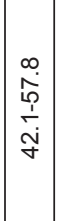 & $\mid$\begin{tabular}{l|}
0 \\
0 \\
0 \\
0 \\
0 \\
0 \\
0
\end{tabular} & $\begin{array}{l}0 \\
0 \\
0 \\
0 \\
0 \\
\dot{m} \\
\dot{m} \\
\end{array}$ & 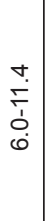 & 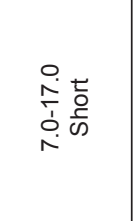 & & 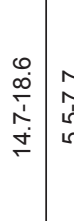 & & 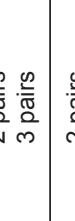 & 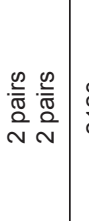 & 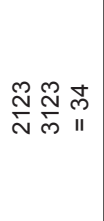 & 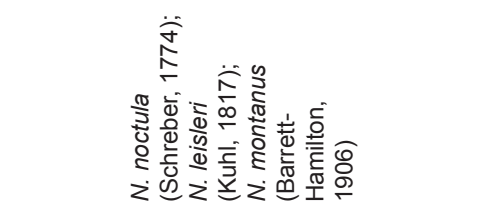 & 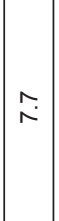 \\
\hline 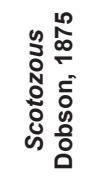 & & $\mid \begin{array}{l}m \\
0 \\
0 \\
i \\
i \\
\tilde{m}\end{array}$ & $\mid$\begin{tabular}{l|}
0 \\
$\dot{b}$ \\
0 \\
0 \\
$\dot{p}$ \\
$\dot{m}$
\end{tabular} & 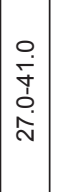 & $\begin{array}{l}0 \\
0 \\
0 \\
0 \\
0 \\
i j\end{array}$ & $\begin{array}{l}0 \\
\infty \\
\stackrel{\infty}{1} \\
\stackrel{0}{\circ}\end{array}$ & & 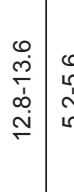 & & 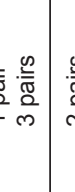 & 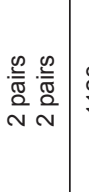 & 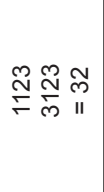 & 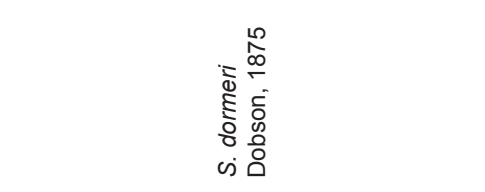 & $\hat{i}$ \\
\hline 总 & 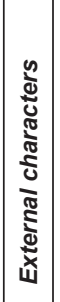 & 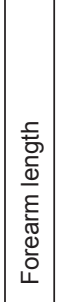 & 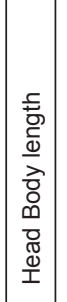 & 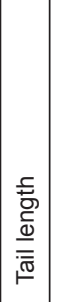 & 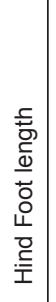 & 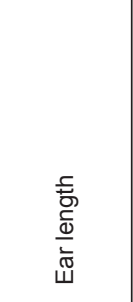 & 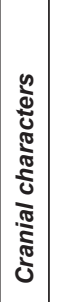 & 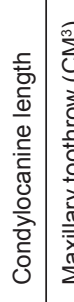 & 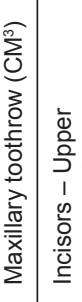 & 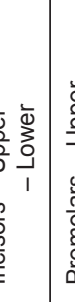 & 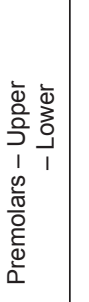 & 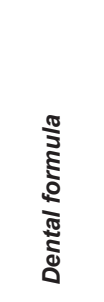 & 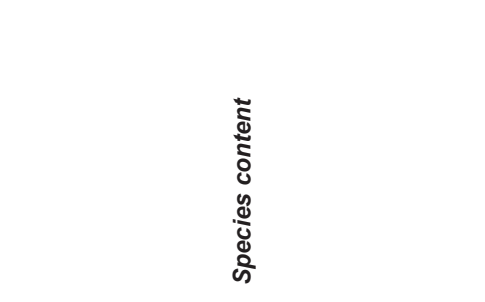 & 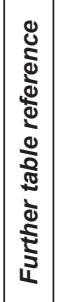 \\
\hline
\end{tabular}


Table 7.1. Diagnostic morphological characters of the species belonging to the genera Harpiocephalus, Harpiola and Murina present in South Asia

\begin{tabular}{|c|c|c|c|}
\hline Species & $\begin{array}{l}\text { Harpiocephalus harpia } \\
\text { (Temminck, 1840) }\end{array}$ & $\begin{array}{l}\text { Harpiola grisea } \\
\text { Peters, } 1872\end{array}$ & $\begin{array}{l}\text { Murina leucogaster } \\
\text { Milne-Edwards, } 1872\end{array}$ \\
\hline \multicolumn{4}{|l|}{ External characters } \\
\hline Forearm length & $44.1-50.1$ & $32.8-34.2$ & $\sim 40.9$ \\
\hline Head Body length & $60.0-75.0$ & $\sim 35.6$ & $\sim 47.0$ \\
\hline Tail length & $40.0-50.0$ & NA & $\sim 35.0$ \\
\hline Hind Foot length & $11.0-14.0$ & NA & $\sim 9.0$ \\
\hline $\begin{array}{l}\text { Ear length } \\
\text { - Posterior border } \\
\text { - Emargination on } \\
\text { posterior border }\end{array}$ & $\begin{array}{l}17.0-18.0 \\
\text { Evenly rounded }\end{array}$ & $\begin{array}{c}\text { NA } \\
\text { NA } \\
\text { Conspicuous }\end{array}$ & $\begin{array}{l}\sim 15.0 \\
\text { Slightly convex } \\
\text { Distinct }\end{array}$ \\
\hline Interfemoral membrane & $\begin{array}{l}\text { Covered with long } \\
\text { reddish hairs }\end{array}$ & $\begin{array}{l}\text { Densely covered with } \\
\text { rather long hairs }\end{array}$ & $\begin{array}{l}\text { Moderately covered with long fine } \\
\text { reddish hair above and naked } \\
\text { below }\end{array}$ \\
\hline \multicolumn{4}{|l|}{ Cranial characters } \\
\hline Condylocanine length & $19.0-19.5$ & $\sim 12.1$ & $\sim 16.3$ \\
\hline Maxillary toothrow $\left(\mathrm{CM}^{3}\right)$ & $6.5-6.9$ & $\sim 4.9$ & $\sim 6.1$ \\
\hline Mandibular toothrow $\left(\mathrm{CM}_{3}\right)$ & $7.5-8.0$ & $\sim 5.8$ & $\sim 6.6$ \\
\hline Zygomatic breadth & $13.6-13.7$ & NA & $\sim 10.0$ \\
\hline Mandible length & $15.1-16.0$ & $\sim 4.1$ & $\sim 13.1$ \\
\hline
\end{tabular}

Note: All measurements are in mm; NA - Data not available

Contd...

Table 7.1 (Contd..). Diagnostic morphological characters of the species belonging to the genus Murina present in South Asia

\begin{tabular}{|c|c|c|c|c|}
\hline Species & $\begin{array}{c}\text { Murina aurata } \\
\text { Milne-Edwards, } 1872\end{array}$ & $\begin{array}{l}\text { Murina cyclotis } \\
\text { Dobson, } 1872\end{array}$ & $\begin{array}{l}\text { Murina tubinaris } \\
\text { (Scully, 1881) }\end{array}$ & $\begin{array}{l}\text { Murina huttoni } \\
\text { (Peters, 1872) }\end{array}$ \\
\hline \multicolumn{5}{|l|}{ External characters } \\
\hline Forearm length & $27.7-29.6$ & $29.7-34.5$ & $30.1-34.1$ & $32.8-35.4$ \\
\hline Head Body length & $\sim 45.0$ & $38.0-50.0$ & $39.0-48.0$ & $\sim 48.0$ \\
\hline Tail length & $\sim 27.0$ & $32.0-41.0$ & $22.0-35.0$ & $\sim 37.0$ \\
\hline Hind Foot length & $\sim 4.5$ & $7.0-10.0$ & $6.0-9.0$ & $\sim 6.0$ \\
\hline $\begin{array}{l}\text { Ear length } \\
\text { - Posterior border } \\
\text { - Emargination on } \\
\text { posterior border }\end{array}$ & $\begin{array}{l}\sim 13.0 \\
\text { Slightly convex } \\
\text { Lacking }\end{array}$ & $\begin{array}{l}13.0-16.0 \\
\text { Slightly convex } \\
\text { Lacking }\end{array}$ & $\begin{array}{c}13.0-15.0 \\
\text { Smoothly convex } \\
\text { Small }\end{array}$ & $\begin{array}{l}\sim 17.0 \\
\text { Smoothly convex } \\
\text { Lacking }\end{array}$ \\
\hline Interfemoral membrane & $\begin{array}{l}\text { Moderately covered with } \\
\text { golden hair above \& gray } \\
\text { hair below }\end{array}$ & $\begin{array}{l}\text { Moderately covered with } \\
\text { orange hairs above \& } \\
\text { nearly naked below }\end{array}$ & $\begin{array}{l}\text { Moderately covered with } \\
\text { pale gray or ferruginous } \\
\text { hairs above } \& \text { naked } \\
\text { below }\end{array}$ & $\begin{array}{c}\text { Moderately covered with } \\
\text { pale brown hairs above \& } \\
\text { naked below }\end{array}$ \\
\hline \multicolumn{5}{|l|}{ Cranial characters } \\
\hline Condylocanine length & $\sim 12.3$ & $13.9-15.0$ & $13.4-14.2$ & $14.9-15.5$ \\
\hline Maxillary toothrow $\left(\mathrm{CM}^{3}\right)$ & $\sim 4.5$ & $5.2-5.7$ & $5.0-5.4$ & $5.8-6.1$ \\
\hline Mandibular toothrow $\left(\mathrm{CM}_{3}\right)$ & $4.5-4.9$ & $5.6-6.2$ & $5.2-5.8$ & $6.4-6.9$ \\
\hline Zygomatic breadth & $\sim 7.5$ & $9.2-9.7$ & $8.4-9.0$ & $9.4-9.8$ \\
\hline Mandible length & $9.2-9.4$ & $10.8-11.8$ & $10.3-10.9$ & $11.5-12.2$ \\
\hline
\end{tabular}

Note: All measurements are in mm; NA - Data not available 
Table 7.2. Diagnostic morphological characters of the species of the genus Kerivoula present in South Asia

\begin{tabular}{|c|c|c|c|}
\hline Species & $\begin{array}{l}\text { Kerivoula picta } \\
\text { (Pallas, 1767) }\end{array}$ & $\begin{array}{l}\text { Kerivoula hardwickii } \\
\text { (Horsfield, 1824) }\end{array}$ & $\begin{array}{c}\text { Kerivoula lenis } \\
\text { Thomas, } 1916\end{array}$ \\
\hline \multicolumn{4}{|l|}{ External characters } \\
\hline Forearm length & $31.5-37.9$ & $31.7-36.0$ & $37.2-41.0$ \\
\hline Head Body length & $45.0-48.0$ & $39.0-55.0$ & NA \\
\hline Tail length & $43.0-48.0$ & $35.0-43.0$ & $\sim 48.0$ \\
\hline Hind Foot length & $4.0-8.0$ & $5.0-8.0$ & NA \\
\hline Ear length & $\begin{array}{l}14.0-16.0 \\
\text { Relatively large, } \\
\text { tip rounded }\end{array}$ & $\begin{array}{l}11.0-15.0 \\
\text { Moderate-sized, } \\
\text { tip rounded }\end{array}$ & $\begin{array}{c}\sim 13.8 \\
\text { Moderate-sized, } \\
\text { tip rounded }\end{array}$ \\
\hline Tragus & $\begin{array}{l}\text { Tall and } \\
\text { narrow }\end{array}$ & $\begin{array}{l}\text { Narrow, } \\
\text { sharply pointed }\end{array}$ & NA \\
\hline Interfemoral membrane & $\begin{array}{l}\text { Orange to scarlet } \\
\text { hairy above along } \\
\text { the body parts }\end{array}$ & $\begin{array}{c}\text { Brown \& nearly } \\
\text { transparent, } \\
\text { sparsely haired } \\
\text { above near body parts } \\
\text { \& posterior border }\end{array}$ & $\begin{array}{c}\text { Without hairs, } \\
\text { veins sometimes } \\
\text { whitish }\end{array}$ \\
\hline \multicolumn{4}{|l|}{ Cranial characters } \\
\hline Condylocanine length & $12.2-13.3$ & $12.4-13.0$ & $14.5-15.1$ \\
\hline Maxillary toothrow $\left(\mathrm{CM}^{3}\right)$ & $5.5-5.8$ & $5.5-5.8$ & $6.6-6.8$ \\
\hline Mandibular toothrow $\left(\mathrm{CM}_{3}\right)$ & $5.9-6.1$ & $5.9-6.1$ & $7.2-7.6$ \\
\hline Zygomatic breadth & $8.4-8.8$ & $8.6-8.7$ & $9.6-10.6$ \\
\hline Mandible length & $10.0-10.7$ & $9.9-10.6$ & $11.8-12.4$ \\
\hline
\end{tabular}

Note: All measurements are in mm; NA - Data not available 


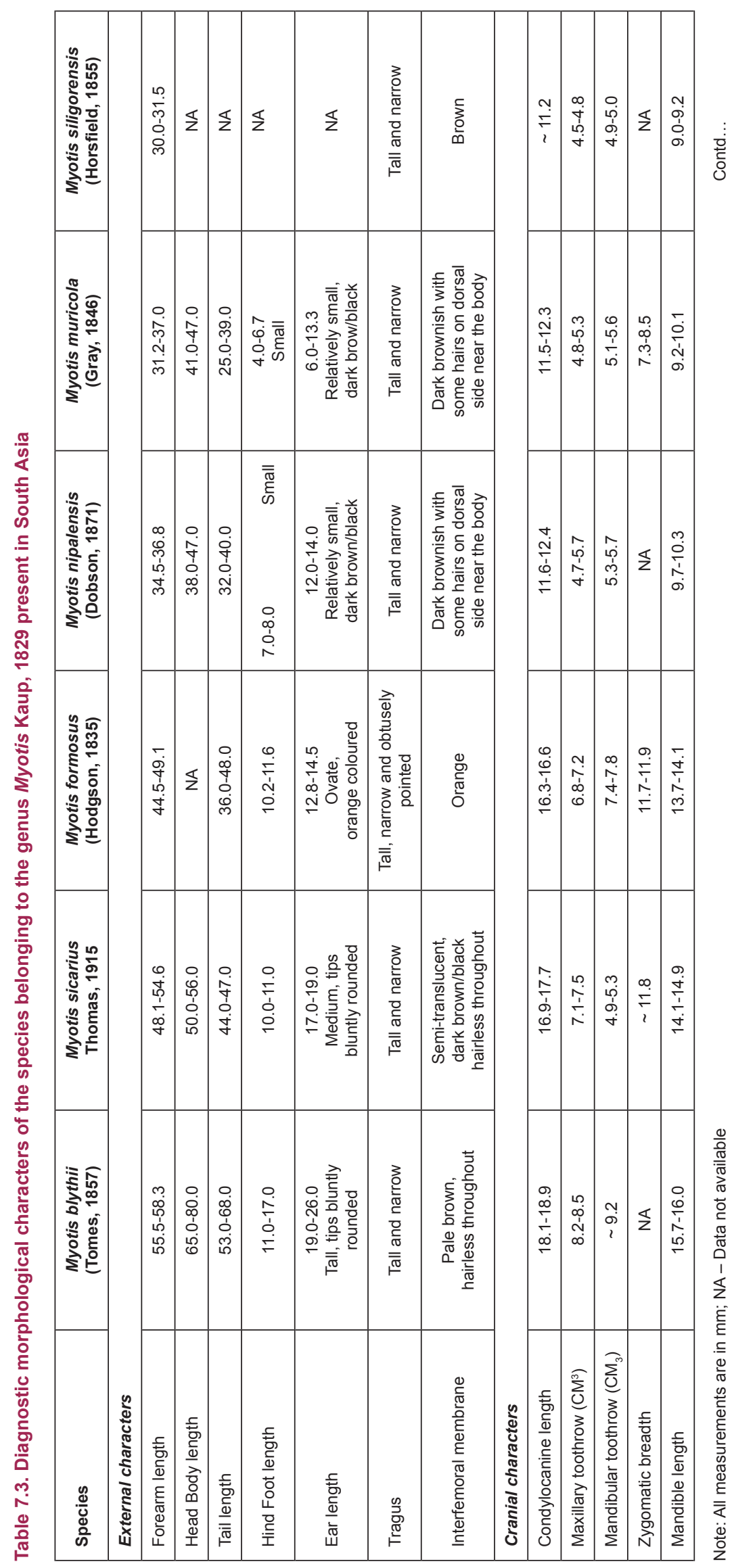




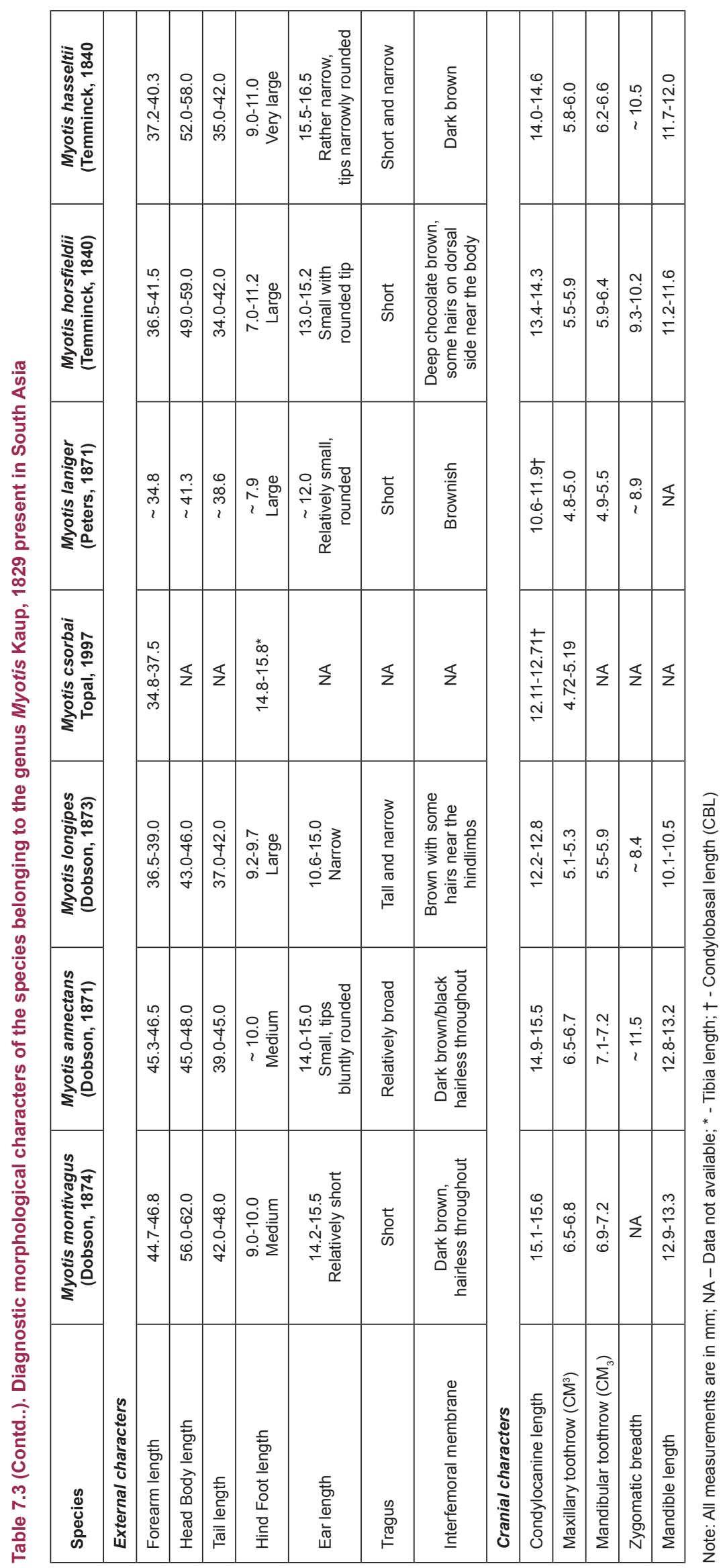


Table 7.4. Diagnostic morphological characters of the species belonging to the genera Plecotus, Barbastella and Otonycteris present in South Asia

\begin{tabular}{|c|c|c|c|c|c|}
\hline Species & $\begin{array}{c}\text { Plecotus } \\
\text { homochrous } \\
\text { Hodgson, } 1847\end{array}$ & $\begin{array}{c}\text { Plecotus } \\
\text { wardi } \\
\text { Thomas, } 1911\end{array}$ & $\begin{array}{c}\text { Plecotus } \\
\text { strelkovi } \\
\text { Spitzenberger, } \\
2008\end{array}$ & $\begin{array}{c}\text { Barbastella } \\
\text { leucomelas } \\
\text { (Cretzschmar, } \\
\text { 1826) }\end{array}$ & $\begin{array}{c}\text { Otonycteris } \\
\text { hemprichii } \\
\text { Peters, } 1859\end{array}$ \\
\hline \multicolumn{6}{|l|}{ External characters } \\
\hline Forearm length & $36.5-40.3$ & $41.9-45.1$ & $39.6-44.9$ & $38.7-42.1$ & $64.7-65.6$ \\
\hline Head Body length & $40.0-45.0$ & $47.0-53.0$ & - & $47.0-51.0$ & $61.0-76.0$ \\
\hline Tail length & $48.0-50.0$ & $49.0-54.0$ & $\sim 51.0$ & $40.0-47.0$ & $40.0-58.0$ \\
\hline Hind Foot length & $7.0-8.0$ & $7.0-9.5$ & - & $7.0-8.0$ & $11.3-12.9$ \\
\hline Ear length & $\begin{array}{l}\text { 39.0-41.0 } \\
\text { Long and oval; } \\
\text { joined over } \\
\text { forehead }\end{array}$ & $\begin{array}{l}\text { 37.0-42.0 } \\
\text { Large and oval; } \\
\text { joined over } \\
\text { forehead }\end{array}$ & $\begin{array}{l}\sim 40.0 \\
\text { Large and oval; } \\
\text { joined over } \\
\text { forehead }\end{array}$ & $\begin{array}{c}15.0-17.0 \\
\text { Small squarish; } \\
\text { joined over } \\
\text { forehead }\end{array}$ & $\begin{array}{c}30.0-42.0 \\
\text { Large and tip } \\
\text { broadly rounded }\end{array}$ \\
\hline Tragus & $\begin{array}{c}\text { Tall, } 1 / 2 \text { the } \\
\text { pinna, tip } \\
\text { bluntly pointed }\end{array}$ & $\begin{array}{l}\text { Tall, } 1 / 2 \text { the } \\
\text { pinna, tip } \\
\text { bluntly pointed }\end{array}$ & $\begin{array}{c}\text { Tall, } 1 / 2 \text { the } \\
\text { pinna, tip } \\
\text { bluntly pointed }\end{array}$ & Triangular & $\begin{array}{l}\text { Tall, } 1 / 2 \text { the } \\
\text { pinna }\end{array}$ \\
\hline Antitragus & Indefinable & Indefinable & Indefinable & Absent & Shallow notch-like \\
\hline \multicolumn{6}{|l|}{ Cranial characters } \\
\hline Condylocanine length & $13.8-14.2$ & $14.8-15.4$ & $14.1-15.6$ & $13.4-14.2$ & $\sim 21.7$ \\
\hline Maxillary toothrow $\left(\mathrm{CM}^{3}\right)$ & $5.0-5.3$ & $5.4-5.8$ & $5.4-6.1$ & $4.7-5.1$ & $\sim 8.5$ \\
\hline Mandibular toothrow $\left(\mathrm{CM}_{3}\right)$ & $5.4-5.7$ & $5.9-6.3$ & $5.8-6.4$ & $5.1-5.7$ & $9.7-9.8$ \\
\hline Zygomatic breadth & $8.1-8.2$ & $8.5-8.9$ & $8.4-9.2$ & 7.3-7.6 & $13.6-15.8$ \\
\hline Mandible length & $9.8-10.2$ & $10.6-11.2$ & $10.4-11.4$ & $9.6-10.1$ & $17.1-17.4$ \\
\hline
\end{tabular}

Note: All measurements are in $\mathrm{mm}$

Table 7.5. Diagnostic morphological characters of the species belonging to the genera Scotoecus, Scotomanes and Scotophilus present in South Asia

\begin{tabular}{|c|c|c|c|c|}
\hline Species & $\begin{array}{c}\text { Scotoecus } \\
\text { pallidus } \\
\text { Dobson, } 1876\end{array}$ & $\begin{array}{l}\text { Scotomanes } \\
\text { ornatus } \\
\text { (Blyth, 1851) }\end{array}$ & $\begin{array}{c}\text { Scotophilus } \\
\text { heathi } \\
\text { Horsfield, } 1831\end{array}$ & $\begin{array}{c}\text { Scotophilus } \\
\text { kuhlii } \\
\text { Leach, } 1821\end{array}$ \\
\hline \multicolumn{5}{|l|}{ External characters } \\
\hline Forearm length & $34.1-37.3$ & $56.1-61.2$ & $55.4-65.8$ & $44.0-56.0$ \\
\hline Head Body length & $50.0-58.0$ & $64.0-85.0$ & $67.0-93.0$ & $60.0-78.0$ \\
\hline Tail length & $34.0-41.0$ & $52.0-66.0$ & $43.0-71.0$ & $40.0-65.0$ \\
\hline Hind Foot length & $6.0-10.0$ & $12.0-15.0$ & $9.0-15.0$ & $8.0-13.0$ \\
\hline Ear length & $\begin{array}{l}12.0-15.0 \\
\text { Moderate with } \\
\text { rounded tip }\end{array}$ & $\begin{array}{l}\text { 19.0-23.0 } \\
\text { Large and tip } \\
\text { broadly rounded }\end{array}$ & $\begin{array}{c}13.0-20.2 \\
\text { Small } \\
\text { with ridges }\end{array}$ & $\begin{array}{c}\text { 9.0-17.0 } \\
\text { Small } \\
\text { with ridges }\end{array}$ \\
\hline Tragus & Long and narrow & $\begin{array}{c}\text { Tall, up to } 1 / 2 \\
\text { the pinna, broad } \\
\& \text { crescent-shaped }\end{array}$ & $\begin{array}{l}\text { Tall, } 1 / 2 \text { the pinna, } \\
\text { crescent-shaped }\end{array}$ & $\begin{array}{l}\text { Tall, } 1 / 2 \text { the pinna, } \\
\text { crescent-shaped }\end{array}$ \\
\hline Antitragus & Indefinable & Indefinable & Well formed & Well formed \\
\hline \multicolumn{5}{|l|}{ Cranial characters } \\
\hline Condylocanine length & $13.8-14.8$ & $20.1-20.9$ & $19.0-21.3$ & $16.3-18.0$ \\
\hline Maxillary toothrow $\left(\mathrm{CM}^{3}\right)$ & $5.5-5.9$ & $7.8-8.5$ & $7.1-8.4$ & $6.1-6.8$ \\
\hline Mandibular toothrow $\left(\mathrm{CM}_{3}\right)$ & $5.9-6.4$ & $8.7-9.4$ & $8.1-9.6$ & $6.9-7.8$ \\
\hline Zygomatic breadth & $\sim 10.5$ & $15.9-17.3$ & $14.5-16.9$ & $12.4-13.7$ \\
\hline Mandible length & $10.9-12.0$ & $16.9-17.9$ & $14.8-18.0$ & $12.9-14.4$ \\
\hline
\end{tabular}

Note: All measurements are in $\mathrm{mm}$ 
Table 7.6. Diagnostic morphological characters of the species belonging to the genus Arielulus, Hesperoptenus and Eptesicus present in South Asia

\begin{tabular}{|c|c|c|c|c|c|}
\hline Species & $\begin{array}{c}\text { Arielulus } \\
\text { circumdatus } \\
\text { (Temminck, 1840) }\end{array}$ & $\begin{array}{c}\text { Hesperoptenus } \\
\text { tickelli } \\
\text { (Blyth, 1851) }\end{array}$ & $\begin{array}{c}\text { Eptesicus } \\
\text { serotinus } \\
\text { (Schreber, 1774) }\end{array}$ & $\begin{array}{l}\text { Eptesicus bottae } \\
\text { (Peters, 1869) }\end{array}$ & $\begin{array}{c}\text { Eptesicus } \\
\text { pachyotis } \\
\text { (Dobson, 1871) }\end{array}$ \\
\hline \multicolumn{6}{|l|}{ External characters } \\
\hline Forearm length & $41.8-43.6$ & $50.0-60.4$ & $54.2-55.1$ & $\sim 42.1$ & $38.0-45.3$ \\
\hline Head Body length & $\sim 95.0$ & $61.0-79.0$ & $\sim 80.0$ & $\sim 57.0$ & $55.0-56.0$ \\
\hline Tail length & $\sim 40.0$ & $44.0-63.0$ & $\sim 58.0$ & $\sim 45.0$ & $40.0-41.0$ \\
\hline Hind Foot length & $\sim 10.0$ & $9.0-14.0$ & $\sim 10.0$ & $\sim 7.0$ & $8.0-9.0$ \\
\hline Ear length & $\begin{array}{l}\quad \sim 15.0 \\
\text { Dark brown to } \\
\text { black, with pale } \\
\text { margins in some } \\
\text { specimens }\end{array}$ & $\begin{array}{l}14.0-18.0 \\
\text { Moderately large, } \\
\text { thick \& fleshy }\end{array}$ & $\begin{array}{l}\sim 14.0 \\
\text { Moderately tall, } \\
\text { dark }\end{array}$ & $\begin{array}{l}\sim 15.0 \\
\begin{array}{c}\text { Moderately tall, } \\
\text { dark }\end{array}\end{array}$ & $\begin{array}{l}13.0-14.0 \\
\text { Triangular with } \\
\text { rounded tip }\end{array}$ \\
\hline Tragus & $\begin{array}{l}\text { Broad with pale } \\
\text { margin }\end{array}$ & $\begin{array}{l}\text { Tall, } 1 / 2 \text { the pinna, } \\
\text { crescent-shaped }\end{array}$ & $\begin{array}{l}\text { Small, less than } \\
1 / 2 \text { the pinna, tip } \\
\text { bluntly } \\
\text { pointed }\end{array}$ & NA & $\begin{array}{l}\text { Short, broadly } \\
\text { rounded } \\
\text { \& curved inwards }\end{array}$ \\
\hline \multicolumn{6}{|l|}{ Cranial characters } \\
\hline Condylocanine length & $14.6-15.6$ & $17.2-19.6$ & $18.3-19.5$ & $\sim 15.0$ & $\sim 21.2^{*}$ \\
\hline Maxillary toothrow $\left(\mathrm{CM}^{3}\right)$ & $6.0-6.5$ & $7.1-8.2$ & 7.1-7.8 & $\sim 5.8$ & NA \\
\hline Mandibular toothrow $\left(\mathrm{CM}_{3}\right)$ & $6.4-6.8$ & $7.9-9.2$ & $8.4-8.7$ & $\sim 6.8$ & NA \\
\hline Zygomatic breadth & $\sim 11.7$ & $13.1-15.4$ & $13.3-14.6$ & NA & NA \\
\hline Mandible length & $11.8-12.7$ & $14.0-16.5$ & $15.0-16.0$ & $\sim 6.2$ & NA \\
\hline
\end{tabular}

Note: All measurements are in mm; NA - Data not available; * - Greatest skull length

Table 7.6 (Contd..). Diagnostic morphological characters of the species belonging to the genus Eptesicus present in South Asia

\begin{tabular}{|c|c|c|c|c|}
\hline Species & $\begin{array}{l}\text { Eptesicus gobiensis } \\
\text { Bobrinskii, } 1926\end{array}$ & $\begin{array}{c}\text { Eptesicus nasutus } \\
\text { Dobson, } 1877\end{array}$ & $\begin{array}{l}\text { Eptesicus dimissus } \\
\text { Thomas, } 1916\end{array}$ & $\begin{array}{c}\text { Eptesicus tatei } \\
\text { Ellerman \& Morrison- } \\
\text { Scott, } 1951\end{array}$ \\
\hline \multicolumn{5}{|l|}{ External characters } \\
\hline Forearm length & $41.0-41.5$ & $35.4-36.9$ & $38.0-42.0$ & $\sim 43.4$ \\
\hline Head Body length & NA & $40.0-46.0$ & $\sim 56.0$ & $\sim 48.5$ \\
\hline Tail length & NA & $38.0-46.0$ & $36.0-41.0$ & $\sim 45.9$ \\
\hline Hind Foot length & NA & $7.0-8.0$ & $\sim 8.0$ & NA \\
\hline Ear length & $\begin{array}{c}14.0-15.0 \\
\text { Moderately tall }\end{array}$ & $\begin{array}{l}12.5-14.0 \\
\text { Small, narrowly } \\
\text { rounded tip }\end{array}$ & $\begin{array}{l}14.0-15.0 \\
\text { Small and rounded }\end{array}$ & $\begin{array}{l}\sim 15.3 \\
\text { Moderately tall, oval, } \\
\text { with rounded tip }\end{array}$ \\
\hline Tragus & NA & $\begin{array}{l}\text { Tall, } 1 / 2 \text { the } \\
\text { pinna }\end{array}$ & NA & $\begin{array}{l}\text { Tall, } 1 / 2 \text { the } \\
\text { pinna }\end{array}$ \\
\hline \multicolumn{5}{|l|}{ Cranial characters } \\
\hline Condylocanine length & $\sim 15.1^{\dagger}$ & $11.7-12.2$ & $\sim 15.4^{\dagger}$ & NA \\
\hline Maxillary toothrow $\left(\mathrm{CM}^{3}\right)$ & $\sim 5.9$ & $4.4-4.8$ & $\sim 5.9$ & NA \\
\hline Mandibular toothrow $\left(\mathrm{CM}_{3}\right)$ & NA & $4.8-5.1$ & NA & NA \\
\hline Zygomatic breadth & NA & $8.4-8.8$ & NA & NA \\
\hline Mandible length & NA & $8.6-9.6$ & NA & NA \\
\hline
\end{tabular}

Note: All measurements are in mm; NA - Data not available; * - Greatest skull length; $†$ - Condylobasal length 
Table 7.7. Diagnostic morphological characters of the species belonging to the genera Nyctalus and Scotozous present in South Asia

\begin{tabular}{|c|c|c|c|c|}
\hline Species & $\begin{array}{c}\text { Nyctalus } \\
\text { noctula } \\
\text { (Schreber, 1774) }\end{array}$ & $\begin{array}{c}\text { Nyctalus } \\
\text { leisleri } \\
\text { (Kuhl, 1817) }\end{array}$ & $\begin{array}{c}\text { Nyctalus } \\
\text { montanus } \\
\text { (Barrett-Hamilton, 1906) }\end{array}$ & $\begin{array}{l}\text { Scotozous dormeri } \\
\text { (Dobson, 1875) }\end{array}$ \\
\hline \multicolumn{5}{|l|}{ External characters } \\
\hline Forearm length & $50.9-57.8$ & $42.1-45.2$ & $42.9-43.0$ & $32.7-36.3$ \\
\hline Head Body length & $68.0-80.0$ & $62.0-72.0$ & $\sim 70.0$ & $39.0-55.0$ \\
\hline Tail length & $33.0-55.0$ & $31.0-45.0$ & $\sim 43.0$ & $27.0-41.0$ \\
\hline Hind Foot length & $10.2-11.4$ & $6.0-10.0$ & NA & $5.0-8.0$ \\
\hline Ear length & $\begin{array}{l}13.0-17.0 \\
\text { Moderate }\end{array}$ & $\begin{array}{l}7.0-16.0 \\
\text { Moderate }\end{array}$ & $\begin{array}{l}\sim 14.0 \\
\text { Short }\end{array}$ & $10.0-18.0$ \\
\hline Tragus & $\begin{array}{c}\text { Club-shaped } \\
\text { expanded distally }\end{array}$ & $\begin{array}{c}\text { Club-shaped } \\
\text { expanded distally }\end{array}$ & $\begin{array}{c}\text { Club-shaped } \\
\text { expanded distally }\end{array}$ & $\begin{array}{l}\text { Without hairs, } \\
\text { veins sometimes whitish }\end{array}$ \\
\hline \multicolumn{5}{|l|}{ Cranial characters } \\
\hline Condylocanine length & $17.1-18.6$ & $14.7-15.2$ & $15.4-16.0$ & $12.8-13.6$ \\
\hline Maxillary toothrow $\left(\mathrm{CM}^{3}\right)$ & 7.1-7.7 & $5.5-5.9$ & $6.5-6.6$ & $5.2-5.6$ \\
\hline Mandibular toothrow $\left(\mathrm{CM}_{3}\right)$ & $7.5-8.2$ & $5.9-6.3$ & $6.9-7.0$ & $5.5-6.1$ \\
\hline Zygomatic breadth & $12.2-13.3$ & $9.8-10.7$ & NA & $9.6-10.5$ \\
\hline Mandible length & $13.8-14.7$ & $11.4-11.7$ & $12.7-12.8$ & $10.4-11.2$ \\
\hline
\end{tabular}

Note: All measurements are in mm; NA - Data not available

Table 7.7 (Contd..). Diagnostic morphological characters of the species belonging to the genus Pipistrellus present in South Asia

\begin{tabular}{|c|c|c|c|c|}
\hline Species & $\begin{array}{l}\text { Pipistrellus pipistrellus } \\
\text { (Schreber, 1774) }\end{array}$ & $\begin{array}{l}\text { Pipistrellus paterculus } \\
\text { Thomas, } 1915\end{array}$ & $\begin{array}{c}\text { Pipistrellus javanicus } \\
\text { (Gray, 1838) }\end{array}$ & $\begin{array}{c}\text { Pipistrellus coromandra } \\
\text { (Gray, 1838) }\end{array}$ \\
\hline \multicolumn{5}{|l|}{ External characters } \\
\hline Forearm length & $30.0-30.6$ & $29.2-34.0$ & $30.0-36.0$ & $25.5-34.3$ \\
\hline Head Body length & $40.0-48.0$ & $42.0-48.0$ & $40.0-55.0$ & $34.0-49.0$ \\
\hline Tail length & $29.0-35.0$ & $31.0-38.0$ & $26.0-40.0$ & $22.0-39.0$ \\
\hline Hind Foot length & $6.0-7.0$ & $6.0-7.0$ & $3.0-8.0$ & $3.4-8.0$ \\
\hline Ear length & $10.5-12.0$ & $10.0-13.0$ & $5.0-15.0$ & $7.1-14.0$ \\
\hline Interfemoral membrane & $\begin{array}{l}\text { Sparsely haired above } \\
\text { near the body parts }\end{array}$ & $\begin{array}{l}\text { Sparsely haired above } \\
\text { near the body }\end{array}$ & Without hairs & $\begin{array}{l}\text { Sparsely haired above } \\
\text { and below near } \\
\text { the body parts }\end{array}$ \\
\hline \multicolumn{5}{|l|}{ Cranial characters } \\
\hline Condylocanine length & $10.4-11.3$ & $10.6-11.6$ & $11.9-13.1$ & $10.6-11.9$ \\
\hline Maxillary toothrow $\left(\mathrm{CM}^{3}\right)$ & $4.1-4.4$ & $4.1-4.8$ & $4.6-5.2$ & $3.9-4.6$ \\
\hline Mandibular toothrow $\left(\mathrm{CM}_{3}\right)$ & $4.3-4.7$ & $4.4-5.0$ & 4.8-5.5 & 4.1-5.1 \\
\hline Zygomatic breadth & $7.2-7.9$ & NA & $8.2-9.0$ & $7.6-8.2$ \\
\hline Mandible length & $7.9-8.7$ & $8.4-9.1$ & $9.3-10.7$ & $8.2-9.5$ \\
\hline Posterior palatal width & $4.8-5.2$ & $5.3-5.9$ & $5.6-6.7$ & $5.0-6.0$ \\
\hline$I^{3} 1 / 2$ or $>$ than $I^{2}$ & Yes & Yes & Yes & Yes \\
\hline Upper canine & Bicuspidate & Unicuspidate & Bicuspidate & Bicuspidate \\
\hline
\end{tabular}


Table 7.7 (Contd.). Diagnostic morphological characters of the species belonging to the genus Pipistrellus present in South Asia

\begin{tabular}{|c|c|c|c|c|}
\hline Species & $\begin{array}{l}\text { Pipistrellus tenuis } \\
\text { (Temminck, 1840) }\end{array}$ & $\begin{array}{l}\text { Pipistrellus ceylonicus } \\
\text { (Kelaart, 1852) }\end{array}$ & $\begin{array}{l}\text { Pipistrellus kuhlii } \\
\text { (Kuhl, 1817) }\end{array}$ & $\begin{array}{l}\text { Pipistrellus abramus } \\
\text { (Temminck, 1840) }\end{array}$ \\
\hline \multicolumn{5}{|l|}{ External characters } \\
\hline Forearm length & $25.0-30.2$ & $33.0-42.0$ & $33.4-36.0$ & $31.4-34.4$ \\
\hline Head Body length & $33.0-45.0$ & $45.0-64.0$ & $35.0-49.0$ & NA \\
\hline Tail length & $20.0-35.0$ & $30.0-45.0$ & $33.0-45.0$ & NA \\
\hline Hind Foot length & $3.0-7.0$ & $6.0-11.0$ & $6.0-8.0$ & 6.4-7.6 \\
\hline Ear length & $5.0-11.0$ & $9.5-14.0$ & $10.0-13.0$ & NA \\
\hline Interfemoral membrane & Without hairs & $\begin{array}{l}\text { Sparsely haired above } \\
\text { and below near } \\
\text { the body parts }\end{array}$ & $\begin{array}{c}\text { Pallid \& } \\
\text { Translucent }\end{array}$ & NA \\
\hline \multicolumn{5}{|l|}{ Cranial characters } \\
\hline Condylocanine length & $9.3-10.7$ & $13.1-14.3$ & $12.0-12.9$ & $11.4-12.8^{*}$ \\
\hline Maxillary toothrow $\left(\mathrm{CM}^{3}\right)$ & $3.5-4.1$ & $5.2-5.9$ & $4.6-5.0$ & $4.2-4.9$ \\
\hline Mandibular toothrow $\left(\mathrm{CM}_{3}\right)$ & $3.8-4.4$ & $5.7-6.5$ & $5.0-5.5$ & $4.6-5.3$ \\
\hline Zygomatic breadth & 7.3-7.6 & $9.2-11.0$ & $8.4-8.7$ & $\sim 8.2$ \\
\hline Mandible length & $7.2-8.3$ & $10.6-12.0$ & $9.3-10.4$ & $8.9-10.0$ \\
\hline Posterior palatal width & $4.5-5.2$ & $6.2-72$ & $5.5-5.9$ & $5.0-6.0$ \\
\hline$I^{3} 1 / 2$ or $>$ than $I^{2}$ & Yes & Yes & No & Yes \\
\hline Upper canine & Bicuspidate & Bicuspidate & Faintly bicuspidate & Unicuspidate \\
\hline
\end{tabular}

Note: All measurements are in mm; NA - Data not available; * - Condylobasal length

Table 7.8. Diagnostic morphological characters of species of the genera Tylonycteris, la, Falsistrellus and Vespertilio present in South Asia

\begin{tabular}{|c|c|c|c|c|c|}
\hline Species & $\begin{array}{c}\text { Tylonycteris } \\
\text { pachypus } \\
\text { (Temminck, 1840) }\end{array}$ & $\begin{array}{c}\text { Tylonycteris } \\
\text { robustula } \\
\text { Thomas, } 1915\end{array}$ & $\begin{array}{c}\text { la io } \\
\text { Thomas, } 1902\end{array}$ & $\begin{array}{c}\text { Falsistrellus } \\
\text { affinis } \\
\text { (Dobson, 1871) }\end{array}$ & $\begin{array}{c}\text { Vespertilio } \\
\text { murinus } \\
\text { Linnaeus, } 1758\end{array}$ \\
\hline \multicolumn{6}{|l|}{ External characters } \\
\hline Forearm length & $26.1-29.0$ & $26.6-28.1$ & $70.9-77.3$ & $38.4-41.4$ & $42.0-45.5$ \\
\hline Head Body length & $34.0-46.0$ & $40.0-44.0$ & NA & $43.0-51.0$ & $55.0-66.0$ \\
\hline Tail length & $26.0-33.0$ & $26.0-31.0$ & $\sim 65.0$ & $30.0-41.0$ & $40.0-48.0$ \\
\hline Hind Foot length & $5.0-7.0$ & $5.0-5.5$ & $\sim 17.0$ & $7.0-8.0$ & $8.0-10.0$ \\
\hline Ear length & $\begin{array}{l}9.0-10.0 \\
\text { Small, triangular } \\
\text { with broadly } \\
\text { rounded tip }\end{array}$ & $\begin{array}{l}8.5-10.5 \\
\text { Small, triangular } \\
\text { with broadly } \\
\text { rounded tip }\end{array}$ & $\begin{array}{l}23.7-24.0 \\
\text { Large, broad with } \\
\text { rounded tip }\end{array}$ & $12.0-15.0$ & $\begin{array}{c}14.7-16.0 \\
\text { Short and tip } \\
\text { broadly rounded }\end{array}$ \\
\hline Tragus & $\begin{array}{c}\text { Short and } \\
\text { broad }\end{array}$ & $\begin{array}{c}\text { Short and } \\
\text { broad }\end{array}$ & $\begin{array}{l}\text { Small, } 1 / 3^{\text {rd }} \text { the } \\
\text { pinna }\end{array}$ & & $\begin{array}{c}\text { Small, short } \\
\text { bluntly rounded }\end{array}$ \\
\hline \multicolumn{6}{|l|}{ Cranial characters } \\
\hline Condylocanine length & $10.0-11.3$ & $11.1-11.7$ & $25.2-26.2$ & $13.7-14.7$ & $\sim 15.0$ \\
\hline Maxillary toothrow $\left(\mathrm{CM}^{3}\right)$ & $3.4-4.2$ & $3.9-4.1$ & $10.5-11.0$ & $5.5-5.7$ & $4.9-5.5$ \\
\hline Mandibular toothrow $\left(\mathrm{CM}_{3}\right)$ & $3.6-4.6$ & $5.4-5.8$ & $11.6-12.1$ & $5.6-5.8$ & $5.3-6.1$ \\
\hline Zygomatic breadth & 8.4-8.5 & $8.9-9.1$ & $16.7-18.0$ & $\sim 9.1$ & $9.1-9.7$ \\
\hline Mandible length & $7.6-8.9$ & $8.5-9.0$ & $20.8-21.8$ & $10.5-11.4$ & $10.1-11.4$ \\
\hline
\end{tabular}

Note: All measurements are in $\mathrm{mm}$; NA - Data not available

Contd... 
Table 7.8 (Contd.). Diagnostic morphological characters of species of the genera Philetor and Hypsugo present in South Asia

\begin{tabular}{|c|c|c|c|}
\hline Species & $\begin{array}{l}\text { Philetor brachypterus } \\
\text { (Temminck, 1840) }\end{array}$ & $\begin{array}{c}\text { Hypsugo savii } \\
\text { (Bonaparte, 1837) }\end{array}$ & $\begin{array}{c}\text { Hypsugo cadornae } \\
\text { (Thomas, 1916) }\end{array}$ \\
\hline \multicolumn{4}{|l|}{ External characters } \\
\hline Forearm length & $31.7-35.7$ & $32.1-38.0$ & $32.6-36.5$ \\
\hline Head Body length & NA & $47.0-60.0$ & $47.0-52.5$ \\
\hline Tail length & $27.1-32.2$ & $30.0-35.0$ & $34.0-49.0$ \\
\hline Hind Foot length & $6.4-8.1$ & $6.4-8.0$ & $6.5-7.0$ \\
\hline Ear length & $\begin{array}{c}8.0-10.0 \\
\text { Short and broad, } \\
\text { broadly rounded tip }\end{array}$ & $10.0-14.0$ & $14.0-15.0$ \\
\hline Interfemoral membrane & $\begin{array}{l}\text { Broad \& short, } \\
\text { fleshy \& thick }\end{array}$ & $\begin{array}{c}\text { Sparsely haired } \\
\text { near the body and tail }\end{array}$ & Without hairs \\
\hline \multicolumn{4}{|l|}{ Cranial characters } \\
\hline Condylocanine length & $12.4-13.7$ & $11.4-13.3$ & $12.6-12.8$ \\
\hline Maxillary toothrow $\left(\mathrm{CM}^{3}\right)$ & $4.5-4.8$ & $4.6-5.1$ & $4.6-4.9$ \\
\hline Mandibular toothrow $\left(\mathrm{CM}_{3}\right)$ & $4.7-5.0$ & $4.9-5.2$ & $4.8-5.1$ \\
\hline Zygomatic breadth & $10.0-10.7$ & $8.5-9.1$ & NA \\
\hline Mandible length & $9.9-10.7$ & $9.6-10.3$ & $9.5-10.3$ \\
\hline
\end{tabular}

Note: All measurements are in mm; NA - Data not available

Table 8. Diagnostic morphological characters of one genus of the family Miniopteridae present in South Asia

\begin{tabular}{|c|c|}
\hline Genus & Miniopterus Bonaparte, 1837 \\
\hline \multicolumn{2}{|l|}{ External characters } \\
\hline Forearm length & $39.6-49.6$ \\
\hline Head Body length & $40.1-65.0$ \\
\hline Tail length & $39.6-61.0$ \\
\hline Hind Foot length & $\sim 7.0-12.0$ \\
\hline Ear length & $\begin{array}{c}\quad \sim 8.7-12.0 \\
\text { Small and tip broadly rounded }\end{array}$ \\
\hline \multicolumn{2}{|l|}{ Cranial characters } \\
\hline Condylocanine length & $12.0-14.8$ \\
\hline Maxillary toothrow $\left(\mathrm{CM}^{3}\right)$ & $5.1-6.3$ \\
\hline $\begin{array}{r}\text { Incisors - Upper } \\
\text { - Lower }\end{array}$ & $\begin{array}{l}2 \text { pairs } \\
3 \text { pairs }\end{array}$ \\
\hline $\begin{array}{r}\text { Premolars - Upper } \\
\text { - Lower }\end{array}$ & $\begin{array}{l}2 \text { pairs } \\
3 \text { pairs }\end{array}$ \\
\hline Dental formula & $\begin{array}{c}-23,1,-2-4,123 \\
123,1,-234,123 \\
=36\end{array}$ \\
\hline Species content & $\begin{array}{l}\text { M. schreibersii (Kuhl, 1817); } \\
\text { M. pusillus Dobson, } 1876 \\
\text { M. magnater Sanborn, } 1931\end{array}$ \\
\hline Further table reference & 8.1 \\
\hline
\end{tabular}

Note: All measurements are in $\mathrm{mm}$ 
Table 8.1. Diagnostic morphological characters of species of the genera Miniopterus Bonaparte, 1837 present in South Asia

\begin{tabular}{|c|c|c|c|}
\hline Species & $\begin{array}{c}\text { Miniopterus schreibersii } \\
\text { (Kuhl, 1817) }\end{array}$ & $\begin{array}{l}\text { Miniopterus pusillus } \\
\text { (Dobson, 1876) }\end{array}$ & $\begin{array}{c}\text { Miniopterus magnater } \\
\text { Sanborn, } 1931\end{array}$ \\
\hline \multicolumn{4}{|l|}{ External characters } \\
\hline Forearm length & $44.7-49.6$ & $39.6-40.2$ & $47.0-53.0$ \\
\hline Head Body length & $47.0-65.0$ & NA & NA \\
\hline Tail length & $44.0-61.0$ & $40.1-44.1$ & NA \\
\hline Hind Foot length & $7.0-12.0$ & NA & NA \\
\hline Ear length & $\begin{array}{c}8.7-12.0 \\
\text { Small, tip broadly rounded }\end{array}$ & NA & NA \\
\hline Tragus & $\begin{array}{l}1 / 2 \text { the pinna, slightly curved } \\
\text { forward }\end{array}$ & NA & NA \\
\hline Interfemoral membrane & $\begin{array}{l}\text { Dark brownish-black, sparely } \\
\text { haired near the body parts }\end{array}$ & $\begin{array}{l}\text { Dark brownish-black, fur on } \\
\text { membrane extends further away } \\
\text { from body parts }\end{array}$ & NA \\
\hline \multicolumn{4}{|l|}{ Cranial characters } \\
\hline Condylocanine length & $13.6-14.8$ & $12.0-12.7$ & $16.8-17.3^{\dagger}$ \\
\hline Maxillary toothrow $\left(\mathrm{CM}^{3}\right)$ & $5.8-6.3$ & $5.1-5.3$ & $7.0-7.2$ \\
\hline Mandibular toothrow $\left(\mathrm{CM}_{3}\right)$ & $6.3-6.8$ & $5.4-5.6$ & 8.3-8.9 \\
\hline Zygomatic breadth & $8.5-9.1$ & $7.5-7.6$ & $10.0-10.2$ \\
\hline Mandible length & $10.7-11.8$ & $9.3-10.0$ & 13.3-13.9 \\
\hline
\end{tabular}

Note: All measurements are in mm; NA - Data not available; † - Condylobasal length

Andersen, K. (1912). Catalogue of the Chiroptera in the collection of the British Museum, vol. I: Megachiroptera. British Museum (Natural History) London, 854pp.

Andersen, K. (1918). Diagnoses of new bats of the families Rhinolophidae and Megadermatidae. Annals and Magazine of Natural History 2: 374-384.

Andersen, K. \& R.C. Wroughton (1907). On bats of the family Megadermatidae. Annals and Magazine of Natural History 19: 129-145.

Anderson, J. (1881). Catalogue of the Mammalia in the Indian Museum, Calcutta. Part I. Primates, Prosimiae, Chiroptera and Insectivora. Calcutta.

Barrett-Hamilton, G.E.H. (1906). Description of two new species of Pterygistes. Annals and Magazine of Natural History 17: 98-100.

Barrett-Hamilton, G.E.H. (1907). Description of two new species of Plecotus. Annals and Magazine of Natural History 20: 520-521.

Bates, P.J.J. \& D.L. Harrison (1997). Bats of the Indian Subcontinent. Harrison Zoological Museum Publications, Sevenoaks, UK, 258pp.

Bates, P.J.J., D.L. Harrison \& M. Muni (1994a). The Bats of Western India - Part 1. Journal of the Bombay Natural History Society 91(1): 1-15.

Bates, P.J.J., D.L. Harrison \& M. Muni (1994b). The Bats of Western India - Part 2. Journal of the Bombay Natural History Society 91(2): 224-240.

Bates, P.J.J., D.L. Harrison \& M. Muni (1994c). The Bats of Western India - Part 3: Journal of the Bombay Natural History Society 91(3): 360-380.

Bates, P.J.J., D.L. Harrison, N.M. Thomas \& M. Muni (1994d).
The Indian fruit bat Latidens salimalii Thonglongya, 1972 (Chiroptera: Pteropodidae) rediscovered in southern India. Bonner Zoologische Beitrage 45(2): 89-98.

Bhat, H.R. (1968a). Dobson's long nosed fruit bat, Eonycteris spelaea (Dobson), from Kumaon Hills, U.P.: an addition to the chiropteran fauna of India. Journal of the Bombay Natural History Society 64: 550-551.

Bhat, H.R. (1968b). Sphaerias blanfordi (Thomas, 1891) from Himalayan region of Uttar Pradesh: an addition to the chiropteran fauna of India. Journal of the Bombay Natural History Society 65: 471-473.

Bhat, H.R. (1974). Records and observations on bats of Himalayan region of Uttar Pradesh and West Bengal, India. Journal of the Bombay Natural History Society 71(1): 51-57.

Bhattacharyya, T.P. (1975). Occurrence of Dobson's longtongued fruit bat, Eonycteris spelaea (Dobson) (Mammalia: Chiroptera: Pteropidae) in the Andaman Islands, India. Science Culture 41(7): 317-318.

Blanford, W.T. (1888-91). The Fauna of British India, Mammalia. Taylor \& Francis, London, 617pp. (in two parts).

Blyth, E. (1846). Notes on the fauna of the Nicobar Islands. Journal of the Asiatic Society of Bengal 15: 367-369.

Blyth, E, (1863). Catalogue of the Mammalia in the Museum Asiatic Society. Calcutta, 187+xiii pp.

Bogdanowicz, W. (1994). Myotis daubentonii. Mammalian Species 475: 1-9.

Brosset, A. (1962a). The bats of central and western India Part I. Journal of the Bombay Natural History Society 59: 1-57.

Brosset, A. (1962b). The bats of central and western India Part II. Journal of the Bombay Natural History Society 59: 
583-624.

Brosset, A. (1962c). The bats of central and western India Part III. Journal of the Bombay Natural History Society 59: 707-746.

Brosset, A. (1963). The bats of central and western India. Part. IV. Journal of the Bombay Natural History Society 60: 337355.

Carter, T.D. (1943). The Mammals of the Vernay-Chindwin Expedition, Northern Burma. Bulletin of the American Museum Natural History 82(4): 95-114.

Chakraborty, S. (1975). On a collection of Mammals from Bhutan. Records of the Zoological Survey of India 68: 1-20.

Chakraborty, S. (1983). Contribution to the knowledge of the mammalian fauna of Jammu and Kashmir, India. Records of the Zoological Survey of India Miscellanous Publications, Occasional Paper No. 38: 1-129.

Chasen, F.N. (1940). A handlist of Malaysian mammals. Bulletin Raffles Museum 15: 209

Corbet, G.B. (1978). The Mammals of the Palaearctic Region: a taxonomic review. British Museum (Natural History), London, $314 \mathrm{pp}$.

Corbet, G.B. \& J.E. Hill (1986). A World List of Mammalian Species. British Museum (Natural History, London, 226pp.

Corbet, G.B. \& J.E. Hill (1992). The Mammals of the Indomalayan Region. British Museum (Natural History)/ Oxford University Press, London, 488pp.

Csorba, G. \& P.J.J. Bates (1995). A new subspecies of the Horseshoe bat Rhinolophus macrotis from Pakistan (Chiroptera, Rhinolophidae). Acta Zoologica Academy Scientorum Hungaricae 41(3): 285-293.

Das, P.K. (1986). Studies on the taxonomy and geographical distribution of the species of bat obtained by the Silent Valley (Kerala, India) expedition, 1980. Records of the Zoological Survey of India 84(1): 259-276.

Das, P.K. \& Y.P. Sinha (1995). Occurrence of the Japanese Pipistrelle, Pipistrellus abramus (Temminck, 1840) (Chiroptera: Vespertilionidae) in Myanmar (Burma) and India. Journal of the Bombay Natural History Society 92: 252-254.

Das, P.K., R.K. Ghose, T.K. Chakraborty, T.P. Bhattacharyya \& M.K. Ghosh (1995). Mammalia, pp.23-128. In: Director, ZSI (ed.). State Fauna Series 4: Fauna of Meghalaya, Part 1. Zoological Survey of India, Calcutta.

Das, P.K., J.P. Lal \& V.C. Agrawal (1993). Mammalia. pp.143180. In: Director, ZSI (ed.), State Fauna Series I: Fauna of Orissa, Part 4. Zoological Survey of India, Calcutta.

Dobson, G.E. (1872). Brief description of five new species of rhinolophine bats. Journal of the Asiatic Society of Bengal 41: 336-338.

Dobson, G.E. (1873a). Description of a new species of Vespertilio from the northwestern Himalaya. Journal of the Asiatic Society of Bengal 42(2): 205-206.

Dobson, G.E. (1873b). On the genera Murina and Harpyiocephalus of Gray. Proceedings of the Asiatic Society of Bengal, pp.107-110.

Dobson, G.E. (1874a). On the Asiatic species of Molossi. Journal of the Asiatic Society of Bengal 43(2): 142-144.

Dobson, G.E. (1874b). List of Chiroptera inhabiting the Khasia Hills, with description of new species. Journal of the Asiatic Society of Bengal 43(2): 234-236.

Dobson, G.E. (1874c). Descriptions of new species of
Chiroptera from India and Yunan. Journal of the Asiatic Society of Bengal 43(2): 237-238.

Dobson, G.E. (1875). Description of new species of Vespertilionidae. Annals and Magazine of Natural History 16: $260-262$

Dobson, G.E. (1876). Monograph of the Asiatic Chiroptera and catalogue of the species of bats in the collection of the Indian Museum, Calcutta. London.

Dobson, G. E. (1878). Catalogue of the Chiroptera in the collection of the British Museum. London, 567pp.

Ellerman, J.R. \& T.C.S. Morrison-Scott (1951). Checklist of Palaearctic and Indian Mammals 1758 to 1946. British Museum (Nat Hist), London, 810pp.

Finn, F. (1929). Sterndale's mammalia of India. Thacker, Spink \& Co., Madras, 347pp.

Fry, T.B. (1925). Report No 37a: Nepal. Bombay Natural History Society's Mammal Survey of India, Burma and Ceylon. Journal of the Bombay Natural History Society 30: 525530.

Fry, T.B. (1928). Report No 46: On a collection from Toungoo, Burma. Bombay Natural History Society's Mammal Survey of India, Burma and Ceylon. Journal of the Bombay Natural History Society 30: 545-547.

Gharaibeh, B.M. \& M.Z. Qumsiyeh (1995). Otonycteris hemprichii. Mammalian Species 514: 1-4.

Gray, J.E. (1870). Catalogue of monkeys, lemurs, and fruiteating bats in the collection of the British Museum. Trustees of the British Museum, London (dated 1870 but published 1871). i-viii, 1-137.

Hill, J.E. (1958). Some observations on the fauna of the Maldive Islands. Part II. Mammals. Journal of the Bombay Natural History Society 55: 3-10.

Hill, J.E. (1961). Indo-Australian bats of the genus Tadarida. Mammalia 25: 29-56.

Hill, J.E. (1962). Notes on some insectivores and bats from Upper Burma. Proceedings of the Zoological Society of London 139(1): 119-137.

Hill, J.E. (1963). Occurrence of the European free-tailed bat [Tadarida teniotis (Rafinesque)] (Chiroptera: Molossidae) in India. Journal of the Bombay Natural History Society 60: 723-725.

Hill, J.E. (1965). Asiatic bats of the genera Kerivoula and Phoniscus (Vespertilionidae), with a note on Kerivoula aerosa Tomes. Mammalia 29: 524-556.

Hill, J.E. (1966). A review of the genus Philetor (Chiroptera: Vespertilionidae). Bulletin of the British Museum (Natural History), Zoology Series 14: 371-387.

Hill, J.E. (1967). The bats of the Andaman and Nicobar Island. Journal of the Bombay Natural History Society 64(1): 1-9.

Hill, J.E. (1971a). A note on Pteropus (Chiroptera: Pteropidae) from the Andaman Islands. Journal of the Bombay Natural History Society 68(1): 1-8.

Hill, J.E. (1971b). The bats of Aldabra Atoll, western Indian Ocean. Philosophical Transactions of the Royal Society (B) 260: 573-577.

Hill, J.E. (1972). The status of Vespertilio brachypterus Temminck, 1840 (Chiroptera: Vespertilionidae). Zoologische Mededelingen, Leiden 45(12): 139-146.

Hill, J.E. (1974). A review of Scotoecus Thomas, 1901 (Chiroptera: Vespertilionidae). Bulletin of the British Museum of Natural History (Zoology) 27(4): 169-188. 
Hill, J. E. (1976a). Bats referred to Hesperoptenus Peters, 1869 (Chiroptera: Vespertilionidae) with the description of a new subgenus. Bulletin of the British Museum of Natural History (Zoology) 32: 1-28.

Hill, J.E. (1976b). Further records of Myotis peshwa (Thomas 1915) (Chiroptera: Vespertilionidae) from the Indian peninsula. Journal of the Bombay Natural History Society 73(3): 433-437.

Hill, J.E. (1977). A review of the Rhinopomatidae (Mammalia: Chiroptera). Bulletin of British Museum Natural History (Zoology) 32(2): 29-43.

Hill, J.E. (1983). Bats (Mammalia: Chiroptera) from IndoAustralia. Bulletin of British Museum Natural History (Zoology) 45: 103-208.

Hill, J.E. (1986). A note on Rhinolophus pearsoni Horsfield, 1851 and Rhinolophus yunanensis Dobson, 1872 (Chiroptera: Rhinolophidae). Journal of the Bombay Natural History Society 83(Supl.) (Centenary issue): 12-18.

Hill, J.E. \& D.L. Harrison (1987). The baculum in the Vespertilioninae (Chiroptera: Vespertilionidae) with a systematic review, a synopsis of Pipistrellus and Eptesicus, and the descriptions of a new genus and subgenus. Bulletin of British Museum Natural History (Zoology) 52: 225-305.

Hill, J.E. \& J.D. Smith (1984). Bats: A natural history. British Museum (Natural History), London, 243pp.

Hinton, M.A.C. \& T.B. Fry (1923). Report No. 37: Nepal. Bombay Natural History Society's Mammal Survey of India, Burma and Ceylon. Journal of the Bombay Natural History Society 29: 399-428.

Hinton, M.A.C. \& H.M. Lindsay (1926). Report No 41: Assam and Mishmi Hills. Bombay Natural History Society's Mammal Survey of India, Burma and Ceylon. Journal of the Bombay Natural History Society 31: 383-403.

Hinton, M.A.C. \& O. Thomas (1926). Report No 42: Kashmir and Punjab. Bombay Natural History Society's Mammal Survey of India, Burma and Ceylon. Journal of the Bombay Natural History Society 31: 606-614.

Hutson, A.M., S.P. Mickleburgh \& P.A. Racey (compilers) (2001). Microchiropteran Bats: Global Status, Survey and Conservation Action Plan. International Union for Conservation of Nature and Natural Resources, Chiroptera Specialist Group (IUCN/SSC). Gland, Switzerland.

Hutton, A.F. (1949a). Notes on snakes and mammals of the High Wavy Mountains, Madurai District, S. India. Journal of the Bombay Natural History Society 48: 454-460.

Hutton, A.F. (1949b). Notes on snakes and mammals of the High Wavy Mountains, Madurai District, S. India. Journal of the Bombay Natural History Society 48: 681-694.

Hutton, T. (1872). On the bats of the north-western Himalayas. Proceeding zool. Society Lond, pp.690-714.

Jerdon, T.C. (1874). The Mammals of India: a natural history of all the animals known to inhabit continental India. John Wheldon, London, $335 \mathrm{pp}$.

Johnson, D.H., S.D. Ripley \& K. Thonglongya (1980). Mammals from Nepal. Journal of the Bombay Natural History Society 77: 56-63.

Khajuria, H. (1953). Taxonomic studies on some Indian Chiroptera. Records of the Indian Museum 50: 113-128.

Khajuria, H. (1970). A new Leaf nosed bat from central India. Mammalia 34: 622-627.

Khajuria, H. (1979a.) Taxonomical and ecological studies on bats of Jabalpur District Madhya Pradesh, India. Part. I. (Families Pteropidae, Rhinopomatidae and Embalonuridae). Records of the Zoological Survey of India Miscellaneous Publications, Occasional Paper No. 13: 1-59.

Khajuria, H. (1980). Taxonomical and ecological studies on bats of Jabalpur District Madhya Pradesh, India. Part. 11. Families Megadermatidae, Rhinolophidae and Vespertilionidae. Records of the Zoological Survey of India Miscellaneous Publications, Occasional Paper No. 19: 1-69.

Khajuria, H. (1984). Notes on some central Indian bats. Journal of the Zoological Society of India 36 (1-2): 125-126.

Khajuria, H., Y. Chaturvedi \& D.K. Ghosal (1977). Annotated catalogue of type specimens of mammals in zoological survey of India. Records of the Zoological Survey of India Miscellanous Publications, Occasional Paper No. 7: 1-45.

Khajuria, H. \& D.K. Ghosal (1981). Studies on wildlife of Narbada Valley. Part 4. Mammals. Records of the Zoological Survey of India 79(1-2): 235-257.

Khan, R. (1985). Mammals of Bangladesh. Nanna Reza, Dhaka.

Kock, D. \& H.R. Bhat (1994). Hipposideros hypophyllus n. sp. of the $\mathrm{H}$. bicolor-group from peninsular India (Mammalia: Chiroptera: Hipposideridae). Senckenbergiana biologica 73(1-2): 25-31.

Koopman, K.F. (1993). Order Chiroptera In: D. E. Wilson \& D. M. Reeder (eds.), Mammal Species of the World, 2nd ed. Smithsonian Institution Press, Washington. 1206 pp. pp. 137-241.

Kurup, G.U. (1968). Mammals of Assam and adjoining areas. Proceedings of the zoological Society of Calcutta 21: 7999

Lal, J.P. (1982). Andersen's Rufous bat, Rhinolophus rouxi sinicus Andersen (Chiroptera: Rhinolophidae) from Arunachal Pradesh, India. Journal of the Bombay Natural History Society 79(2): 402.

Lindsay, H.M. (1926a). [i] Report No 38: Sind [40-42]; [ii] Report No 39: Mergui Archipelago [42-48]. Bombay Natural History Society's Mammal Survey of India, Burma and Ceylon. Journal of the Bombay Natural History Society 30: 40-48.

Lindsay, H.M. (1926b). Report No 40: Gwalior; Bombay Natural History Society's Mammal Survey of India. Journal of the Bombay Natural History Society 31: 379-382.

Lindsay, H.M. (1927). [i] Report No 43: Nelliampathy plateau and Palni Hills [591-597]; [ii] Report No 44: Kangra and Chamba [597-606]; [iii] Report No 45: The Punjab Salt Range and Murree [606-614]; Bombay Natural History Society's Mammal Survey of India. Journal of the Bombay Natural History Society 31: 591-614.

Meuhauser, H.H. (1970). First positive record of Pipistrellus savii (Chiroptera: Vespertilionidae) from India. Journal of the Bombay Natural History Society 67(2): 319-320.

Mickleburgh, S.P., A.M. Hutson \& P.A. Racey (compilers) (1992). Old World fruit bats. An action plan for their conservation. International Union for Conservation of Nature and Natural Resources, Chiroptera Specialist Group (IUCN/ SSC). Gland, Switzerland, 252pp.

Mickleburgh, S.P., A.M. Hutson \& P.A. Racey (2002). A review of the global conservation status of bats. Oryx 36(1): 18-34.

Miller, G.S. (1902). The mammals of the Andaman and Nicobar Islands. Proceedings of the US National Museum 24(1296): 
751-795.

Miller, G.S. (1903). Seventy new Malaysian mammals. Smithsonian Miscellaneous Collections 45: 1-73.

Miller, G.S. (1906a). Twelve new genera of bats. Proceedings of the Biological Society of Washington 19: 83-86.

Miller, G.S. (1906b). Seven new Malayan bats. Proceedings of the Biological Society of Washington 19: 61-65.

Miller, G.S. (1907). The families and genera of bats. Bulletin of the US National Museum 57: xxvii, 282pp.

Mills, I.C.S. (1921). Report No 36: Naga Hills. Bombay Natural History Society's Mammal Survey of India, Burma and Ceylon. Journal of the Bombay Natural History Society 29: 221-229.

Mirza, Z.B. (1965). Four new mammal records for West Pakistan. Mammalia 29: 205-210.

Mitchell, R.M. (1980). New records of bats (Chiroptera) from Nepal. Mammalia 44(3): 339-342.

Molur, S., G. Marimuthu, C. Srinivasulu, S. Mistry, A.M. Hutson, P.J.J. Bates, S. Walker, K.P. Priya \& A.R.B. Priya (eds.) (2002). Status of South Asian Chiroptera: Conservation Assessment and Management Plan (C.A.M.P.) Workshop Report. Zoo Outreach Organisation, Conservation Breeding Specialist Group South Asia, and Wildlife Information \& Liaison Development Society, Coimbatore, India, viii+154pp.+CD.

Nath, B. (1952). On a collection of mammals from Assam (India) with special reference to the rodents. Records of the Indian Museum 50: 271-285.

Nath, S. (1979). On a collection of microchiropterid bats from Kashmir Valley and adjacent areas, with some new records. Proceedings of the $66^{\text {th }}$ Indian Science Congress III(D): 3.

Phillips, W.W.A. (1923). Further notes on some Ceylon bats. Journal of the Bombay Natural History Society 29: 154-156.

Phillips, W.W.A. (1924). A guide to the Mammals of Ceylon: Chiroptera. Spolia Zeylanica 13: 1-63.

Phillips, W.W.A. (1980). Manual of the Mammals of Sri Lanka. Part I. Wildlife \& Nature Protection Society of Sri Lanka, 1-116pp.

Prakash, I. (1961). Taxonomic and biological observations on the bats of the Rajasthan desert. Records of the Indian Museum 59: 149170.

Prakash, I. (1963). Zoogeography and evolution of the mammalian fauna of Rajasthan desert, India. Mammalia 27: 342-351.

Prater, S.H. (1914). Notes on Wroughton's Free-tailed bat (Otomops wroughtoni). Journal of the Bombay Natural History Society 22: 788.

Roberts, T.J. (1977). The Mammals of Pakistan. Ernest Benn Ltd, 361pp.

Ryley, K.V. (1913a). Report No 9: Mysore. Bombay Natural History Society's Mammal Survey of India. Journal of the Bombay Natural History Society 22(2): 283-295.

Ryley, K.V. (1913b). [i] Report No 10: Kathiawar [464-486]; [ii] Report No 11: Coorg [486-513]. Bombay Natural History Society's Mammal Survey of India. Journal of the Bombay Natural History Society 22: 464-513.

Ryley, K.V. (1914a). Report No 12: Palanpur \& Mount Abu. Bombay Natural History Society's Mammal Survey of India. Journal of the Bombay Natural History Society 22(4): 684699.

Ryley, K.V. (1914b). [i] Report No 13: South Ceylon [700-710]; [ii] Report No 14: North Shan States, Burma [710-725J. Bombay Natural History Society's Mammal Survey of India. Journal of the Bombay Natural History Society 22(4): 700725.

Saha, S.S. (1979). A supplementary note on some mammals recently collected in Bhutan. Journal of the Bombay Natural History Society 76(1): 155-156.

Saha, S.S. (1980). Notes on some mammals recently collected from the Andaman and Nicobar Islands. Records of the Zoological Survey of India 77: 119-126.

Saha, S.S. (1984). Occurrence of the tail-less fruit bat, Megaerops ecaudatus (Temminck, 1837), in Namdapha, Tirap District, Arunachal Pradesh: an addition to the Indian Fauna (Mammalia: Chiroptera: Pteropodidae). Bulletin zool. surv. India 6(I-3): 343-344.

Saha, S.S. (1985). Mammalia. In: Fauna of Namdapha: Arunachal Pradesh 'A proposed biosphere reserve'. Records of the Zoological Survey of India 82(I-4): 321-330.

Scully, J. (1887). On the Chiroptera of Nepal. Journal Asiatic Society Bengal 56: 233-259.

Siddiqi, M.S. (1961). Checklist of Mammals of Pakistan with particular reference to the Mammalian Collection in the British Museum (Natural History), London. Biologia 7(1-2): 93-225.

Sinha, Y.P. (1970). Taxonomic notes on some Indian bats. Mammalia 34: 81-92.

Sinha, Y.P. (1973). Taxonomic studies on the Indian horseshoe bats of the genus Rhinolophus Lacépède. Mammalia 37(4): 603-630.

Sinha, Y.P. (1980). The bats of Rajasthan: taxonomy and zoogeography. Records of the Zoological Survey of India 76(I-4): 7-63.

Sinha, Y.P. (1986). The Bats of Bihar: taxonomy and field ecology. Records of the Zoological Survey of India Miscellanous Publications, Occasional Paper 77: 1-60.

Sinha, Y.P. (1990). Occurrence of Dobson's Long-tongued Fruitbat Eonycteris spelaea (Dobson, 187l) (Chiroptera: Pteropodidae) in Meghalaya. Journal of the Bombay Natural History Society 87: 134

Sinha, Y.P. (1994a). Occurrence of the long-tongued fruit bat Eonycteris spelaea (Dobson, 1871) in Manipur and Nagaland, India. Geobios New Reports 13(2): 186-187.

Sinha, Y.P. (1994b). Occurrence of the Kashmir cave bat, Myotis longipes (Dobson, 1873) in Meghalaya, India. Geobios New Reports 13(1): 68.

Srinivasulu, C. \& B. Srinivasulu (2001). Bats of the Indian subcontinent. Current Science 80(11): 1378-1380.

Tate, G.H.H. (1941a). A review of the genus Hipposideros with special reference to Indo-Australian species. Bulletin of the American Museum of Natural History 78: 353-393.

Tate, G.H.H. (1941b). Notes on vespertilionid bats. Bulletin of the American Museum of Natural History 78: 567-597.

Thomas, N.M. (2000). Morphological and mitochondrialDNA variation in Rhinolophus rouxii (Chiroptera). Bonner Zoologische Beitrage 49(1-4): 1-18.

Thomas, O. (1897). On some bats obtained from the Surat and Thana districts. Journal of the Bombay Natural History Society 11: 274-276.

Thomas, O. (1913). On a remarkable new free-tailed bat from southern Bombay. Journal of the Bombay Natural History Society 22: 87-91. 
Thomas, O. (1915a). Scientific Results from the Mamma Survey No 10: The Indian Bats assigned to the genus Myotis. Journal of the Bombay Natural History Society 23: 607-612.

Thomas, O. (1915b). On pipistrelles of the genera Pipistrellus and Scotozous. Journal of the Bombay Natural History Society 24: 29-36.

Thomas, O. (1915c). On bats of the genera Nyctalus, Tyloncyteris and Pipistrellus. Annals and Magazine of Natural History 16: 225-232.

Thomas, O. (1915d). A special genus for the Himalayan bat known as Murina grisea. Annals and Magazine of Natural History 16: 309-3 10

Thomas, O. (1915e). Notes on Taphozous and Saccolaimus. Journal of the Bombay Natural History Society 24: 57-63.

Thomas, O. (1916a). Scientific results from the Mammal Survey, XIII. Journal of the Bombay Natural History Society 24: 404-430.

Thomas, O. (1916b). Scientific results from the Mammal Survey, XIV. Journal of the Bombay Natural History Society 24: 639-644.

Thomas, O. (1920). A new bat of the genus Myotis from Sikkim. Journal of the Bombay Natural History Society 27: 248250.

Thomas, O. (1921). The geographical races of Scotomanes ornatus. Journal of the Bombay Natural History Society 27 : 772-773.

Thomas, O. (1923). On the forms contained in the genus Harpiocephalus. Journal of the Bombay Natural History Society 29: 88-89.

Thomas, O. (1926). A new Myotis from Ladak. Annals and Magazine of Natural History 17: 609-610.

Thonglongya, K. (1972). A new genus and species of fruit bat from south India (Chiroptera: Pteropodidae). Journal of the Bombay Natural History Society 69(1): 151-158.

Tiwari, K.K., R.K. Ghose \& S. Chakraborty (1971). Notes on a collection of small mammals from Western Ghats, with remarks on the status of Rattus rufescens (Gray) and Bandicota indica malabarica (Shaw). Journal of the Bombay Natural History Society 68: 378-384.

Topal, G. (1970). The first record of la io Thomas, 1902 in Vietnam and India, and some remarks on the taxonomic position of Parascotomanes beaulieui Bourret, 1942, la longimana Pen, 1962, and the genus la Thomas, 1902 (Chiroptera: Vespertilionidae). Opuscula Zoologica, Budapest 10: 341-347.

Topal, G. (1971). The taxonomic position of Myotis dobsoni (Trouessart, 1879) and some statistical data to the subspecific examination of Myotis blythi (Tomes, 1857). Annales Historico-Naturales Musei Nationalis Hungarici (Budapest) 63: 383-399.

Topal, G. (1975). Bacula of some Old World Leaf nosed bats (Rhinolophidae and Hipposideridae, Chiroptera: Mammalia). Vertebrata Hungarica 15: 21-45.

Topal, G. (1997). A new mouse-eared bat species, from Nepal, with statistical analysis of some other species of subgenus Leucone (Chiroptera, Vespertilionidae). Acta Zoologica Academiae Scientiarum Hungaricae 43(4): 375-402.

Walton, D.W. (1974). New records of bats (Chiroptera) from Pakistan. Journal of the Mammalian Society of Japan 6(2): 43-50.
Wroughton, R.C. (1899). Some Konkan bats. Journal of the Bombay Natural History Society 12: 716-725.

Wroughton, R.C. (1912a). Report No 1: East Khandesh. Bombay Natural History Society's Mammal Survey of India. Journal of the Bombay Natural History Society 21(2): 391410.

Wroughton, R.C. (1912b). [i] Report No 2: Berars [820-825]; [ii] Report No 3: Cutch [826-844]; [iii] Report No 4: Nimar [844851]. Bombay Natural History Society's Mammal Survey of India. Journal of the Bombay Natural History Society 21(3): 820-851.

Wroughton, R.C. (1912c). Report No 5: Dharwar. Bombay Natural History Society's Mammal Survey of India. Journal $f$ the Bombay Natural History Society 21(4): 1170-1195.

Wroughton, R.C. (1912d). Some new Indian mammals. Journal of the Bombay Natural History Society 21: 767-773.

Wroughton, R.C. (1913). [I] Report No 6: Kanara [29-44]; [ii] Report No 7 (with K.V. Ryley): Central Provinces [45-58]; [iii] Report No 8 (with K.V. Ryley): Vijayanagar [58-66]. Bombay Natural History Society's Mammal Survey of India. Journal of the Bombay Natural History Society 22(1): 29-66.

Wroughton, R.C. (1914). Report No 15: Kumaon. Bombay Natural History Society's Mammal Survey of India. Journal of the Bombay Natural History Society 22(4): 282-301.

Wroughton, R.C. (1915a). Report No 16: Dry Zone, Central Burma \& Mount Popa. Bombay Natural History Society's Mammal Survey of India, Burma and Ceylon. Journal of the Bombay Natural History Society 23: 460-480.

Wroughton, R.C. (1915b). Report No 17: South Tennasserim, Burma. Bombay Natural History Society's Mammal Survey of India, Burma and Ceylon. Journal of the Bombay Natural History Society 23: 695-720.

Wroughton, R.C. (1915c). [i] Report No 18: Ceylon [7996]; [ii] Report No 19: Bengal, Bihar \& Orissa [96-110]. Bombay Natural History Society's Mammal Survey of India, Burma and Ceylon. Journal of the Bombay Natural History Society24(1): 79-1 10

Wroughton, R.C. (1916a). [i] Report No 20: Chindwin River [291-309]; [ii] Report No 21: Gwalior [309-310]; [iii] Report No 22: Koyna Valley [3II-316]. Bombay Natural History Society's Mammal Survey of India, Burma and Ceylon. Journal of the Bombay Natural History Society 24: 291-316.

Wroughton, R.C. (1916b). Report No 23: Sikkim \& Bengal Terai. Bombay Natural History Society's Mammal Survey of India, Burma and Ceylon. Journal of the Bombay Natural History Society 24: 468-493.

Wroughton, R.C. (1916c). [i] Report No 24: Sind [749-758]; [ii] Report No 25: Chin Hills [758-773]; [iii] Report No 26: Darjiling District [773-781]. Bombay Natural History Society's Mammal Survey of India, Burma and Ceylon. Journal of the Bombay Natural History Society 24(1): 749-781.

Wroughton, R.C. (1917a). Report No 27: Bhutan Duars. Bombay Natural History Society's Mammal Survey of India, Burma and Ceylon. Journal of the Bombay Natural History Society 25(1): 63-71.

Wroughton, R.C. (1917b). Report No 28: Kalimpong (Darjiling). Bombay Natural History Society's Mammal Survey of India, Burma and Ceylon. Journal of the Bombay Natural History Society 25: 274-279.

Wroughton, R.C. (1918a). Summary of the results from the Indian mammal survey. Part 1. Journal of the Bombay 
Natural History Society 25: 547-598.

Wroughton, R.C. (1918b). Summary of the results from the Indian mammal survey. Part 2. Journal of the Bombay Natural History Society 26: 19-58.

Wroughton, R.C. (1920). Report No 32: Baluchistan. Bombay Natural History Society's Mammal Survey of India, Burma and Ceylon. Journal of the Bombay Natural History Society 27: 314-322.

Wroughton, R.C. (1921). [i] Report No 33: High Wavy Mountains, Madura District [545-549]; [ii] Report No 34: Travancore [549-553]; [iii] Report No 35: Prome [553-554]; Bombay Natural History Society's Mammal Survey of India, Burma and Ceylon. Journal of the Bombay Natural History
Society 27: 545554 .

Wroughton, R.C. \& W.M. Davidson (1918). Report No 29: Pegu. Bombay Natural History Society's Mammal Survey of India, Burma and Ceylon. Journal of the Bombay Natural History Society 25: 472-481.

Wroughton, R.C. \& W.M. Davidson (1920). [i] Report No 30: Dekhan, Poona District [1025-1030]; [ii] Report No 31: Nilgiris [1031-1035]. Bombay Natural History Society's Mammal Survey of India, Burma and Ceylon. Journal of the Bombay Natural History Society 25: 1025-1035.

Wroughton, R.C. \& K.V. Ryley (1913). Scientific results from the Mammals Survey, III. Journal of the Bombay Natura History Society 22: 13-21. 